\title{
ENVIRONMENTAL ASSESSMENT OF REMEDIAL ACTION AT THE MAYbell URANIUM Mill TAILINGS Site Near Maybell, Colorado
}

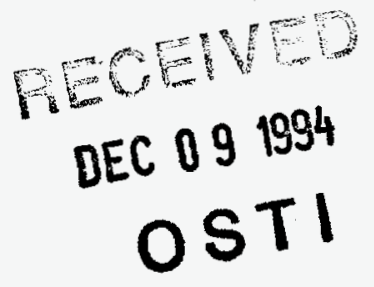

November 1994

\section{DISCLAIMER}

This report was prepared as an account of work sponsored by an agency of the United States Government. Neither the United States Government nor any agency thereof, nor any of their employees, makes any warranty, express or implied, or assumes any legal liability or responsibility for the accuracy, completeness, or usefulness of any information, apparatus, product, or process disclosed, or represents that its use would not infringe privately owned rights. Reference herein to any specific commercial product, process, or service by trade name, trademark, manufacturer, or otherwise does not necessarily constitute or imply its endorsement, recommendation, or favoring by the United States Government or any agency thereof. The views and opinions of authors expressed herein do not necessarily state or reflect those of the United States Government or any agency thereof. 


\section{INTENDED FOR PUBLIC RELEASE}

This report has been reproduced from the best available copy. Available in paper copy and microfiche.

Number of pages in this report: 152

DOE and DOE contractors can obtain copies of this report from:

Office of Scientific and Technical Information

P.O. Box 62

Oak Ridge, TN 37831

(615) 576-8401

This report is publicly available from:

National Technical Information Service

Department of Commerce

5285 Port Royal Road

Springfield, VA 22161

(703) $487-4650$ 


\section{DISCLAIMER}

Portions of this document may be illegible in electronic image products. Images are produced from the best available original document. 
Prepared for

U.S. Department of Energy UMTRA Project Office Albuquerque, New Mexico 


\section{TABLE OF CONTENTS}

Section

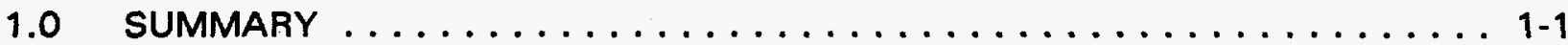

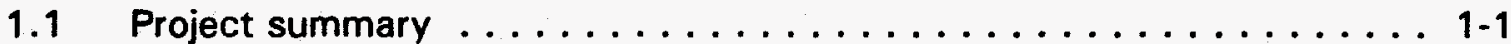

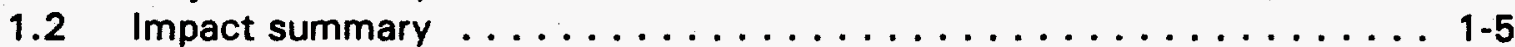

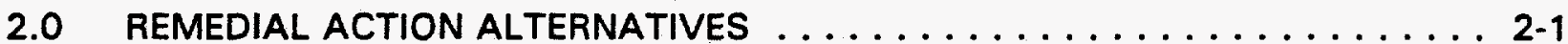

2.1 The need for remedial action . . . . . . . . . . . . . . . 2-1

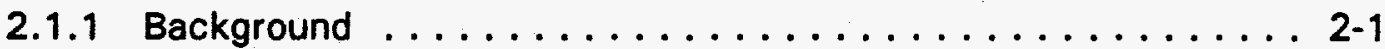

2.1.2 The Maybell tailings site ................. 2-2

2.2 Description of the proposed action: stabilization in place . . . . . . 2-2

2.2.1 Final conditions . . . . . . . . . . . . . . . . 2-3

2.2.2 Implementation of supplemental standards for surface cleanup at the Maybell site ............... 2-7

2.2.3 Implementation of a narrative supplemental standard for ground water protection at the Maybell site . . . . . . . . . 2-8

2.2.4 Borrow sites . . . . . . . . . . . . . . . . . . . 2-9

2.3 Alternatives to the proposed action ................ 2-11

2.3 .1 No action ........................ 2-11

2.3.2 Disposal at the Johnson Pit site . . . . . . . . . . . 2-11

2.3.3 Reprocessing the tailings .................. 2-12

2.3.4 Disposal at the Umetco Minerals Corporation site ....... 2-12

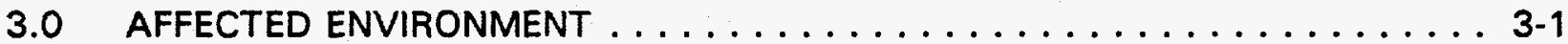

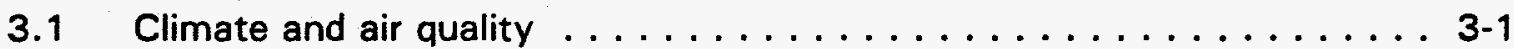

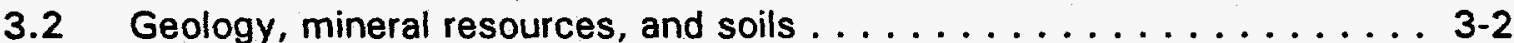

3.2.1 Geology ........................ $3-2$

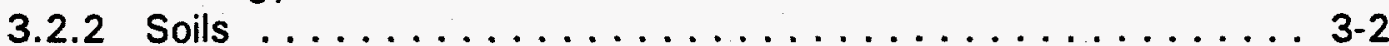

3.2.3 Mineral resources . . . . . . . . . . . . . . . . 3-2

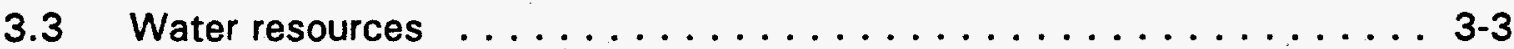

3.3.1 Surface water $\ldots \ldots \ldots \ldots \ldots \ldots \ldots \ldots \ldots \ldots \ldots \ldots . \ldots \ldots$

3.3 .2 Ground water . . . . . . . . . . . . . . . 3-6

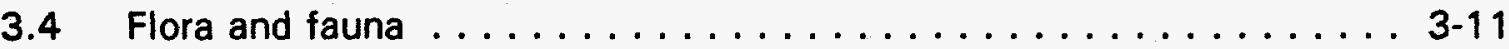

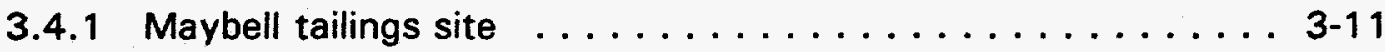

3.4.2 Borrow sites . . . . . . . . . . . . . . . . . 3-13

3.4.3 Threatened and endangered species . . . . . . . . . 3-13

3.5 Radiation ........................... 3-14

3.5.1 Background radiation . . . . . . . . . . . . . . 3-14

3.5.2 Radiation levels . . . . . . . . . . . . . 3-17

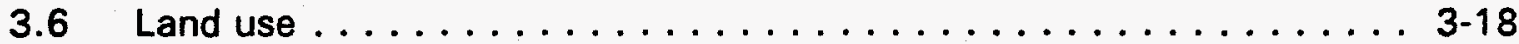

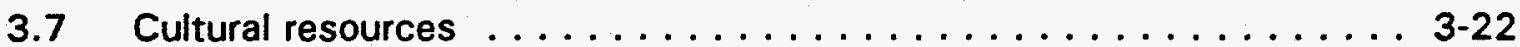

3.8 Socioeconomics . . . . . . . . . . . . . . . . . . . 3-22

3.9 Transportation . . . . . . . . . . . . . . . . . . 3-24

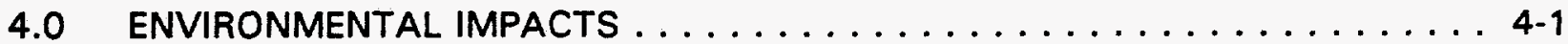

4.1 Introduction ......................... 4-1 


\section{TABLE OF CONTENTS (Concluded)}

Section

Page

4.2 No action alternative $\ldots \ldots \ldots \ldots \ldots \ldots \ldots \ldots \ldots \ldots \ldots$ 4-1

4.3 Proposed action $\ldots \ldots \ldots \ldots \ldots \ldots \ldots \ldots \ldots \ldots \ldots \ldots$ 4-3

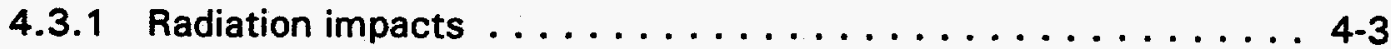

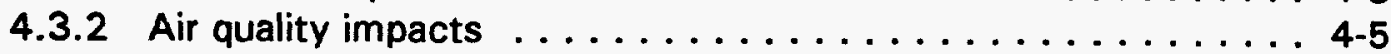

4.3.3 Mineral resources and soils impacts ............. 4-6

4.3.4 Water resources impacts $\ldots \ldots \ldots \ldots \ldots \ldots \ldots \ldots \ldots$ 4-6

4.3.5 Flora and fauna impacts $\ldots \ldots \ldots \ldots \ldots \ldots \ldots \ldots \ldots$ 4-8

4.3.6 Land use impacts $\ldots \ldots \ldots \ldots \ldots \ldots \ldots \ldots \ldots \ldots, 4-11$

4.3.7 Cultural resources impacts ................ 4-13

4.3.8 Socioeconomics impacts $\ldots \ldots \ldots \ldots \ldots \ldots \ldots \ldots \ldots$ 4-13

4.3.9 Transportation impacts $\ldots \ldots \ldots \ldots \ldots \ldots \ldots \ldots \ldots$ 4-14

4.3.10 Noise impacts . . . . . . . . . . . . . . .

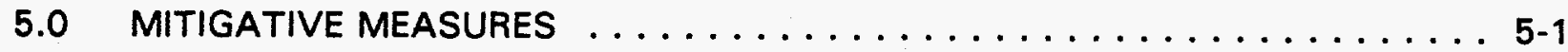

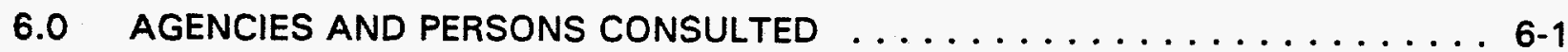

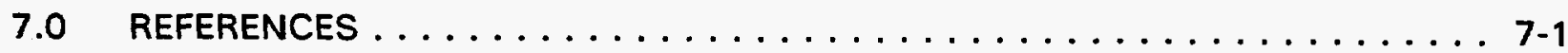

ATTACHMENT 1 BIOLOGICAL ASSESSMENT

APPENDIX 1: SECTION 7 CONSULTATION LETTERS FROM THE U.S. FISH AND WILDLIFE SERVICE

ATTACHMENT 2 FLOODPLAIN/WETLANDS ASSESSMENT 


\section{LIST OF FIGURES}

Figure

1.1 Location map of the Maybell tailings site near Maybell, Colorado . . . . . . . 1-2

1.2 Present conditions at the Maybell tailings site near Maybell, Colorado . . . . . . 1-3

1.3 Approximate boundaries of radium-226 soil contamination and cleanup at the Maybell tailings site near Maybell, Colorado . . . . . . . . . . . . . . 1-4

2.1 Final conditions at the Maybell disposal site near Maybell, Colorado . . . . . . 2-4

2.2 Typical cross section of the Maybell tailings site, near Maybell, Colorado . . . . . . . . . . . . . . . . . . . . . . . . . . . . . . 2-6

2.3 Proposed borrow sites for the Maybell disposal site near Maybell, Colorado . . . . . . . . . . . . . . . . . . . . . . . . . . . 2-10

3.1 Surface water features at the Maybell tailings site near Maybell, Colorado . . . . . . . . . . . . . . . . . . . . . . . . . . . . 3-4

3.2 Potentiometric surface map for the Browns Park Formation aquifer, May 1992, near Maybell, Colorado . . . . . . . . . . . . . . 3-7

\section{LIST OF TABLES}

Table

3.1 Concentrations of selected major ions in surface water samples collected near the Maybell tailings site near Maybell, Colorado . . . . . . . . . . . . . 3-5

3.2 Hazardous constituents detected in ground water and tailings pore water at the Maybell tailings site, Moffat County, Colorado . . . . . . . . . . . . . 3-8

3.3 Maximum observed concentrations for those constituents that have exceeded the state of Colorado's agricultural standards in background monitor wells ........................... 3-10

3.4 Background and on-site radiation measurements for Maybell, Colorado, processing site near Maybell, Colorado . . . . . . . . . . . . . . . . . . 3-15

3.5 Average radionuclide concentrations in sediments from Johnson Wash

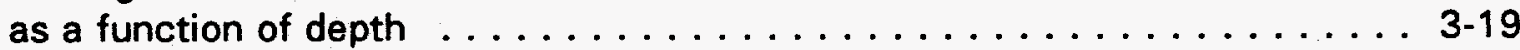

3.6 Average radionuclide concentrations in sediments from Lay Creek as a function of depth . . . . . . . . . . . . . . . . . . 3-20

4.1 Excess health effects for the general public and remedial action workers . . . . 4-2 


\title{
LIST OF ACRONYMS AND ABBREVIATIONS
}

\author{
Acronym Definition \\ ac acre \\ ac/ft acre-foot \\ BLM Bureau of Land Management \\ $\mathrm{Bq} / \mathrm{m}^{2} \mathrm{sec}$ becquerels per square meter per second \\ ${ }^{\circ} \mathrm{C}$ degrees Centigrade \\ cm centimeter \\ $\mathrm{cm} / \mathrm{sec} \quad$ centimeters per second \\ DOE U.S. Department of Energy \\ EA environmental assessment \\ EPA U.S. Environmental Protection Agency \\ of degrees Fahrenheit \\ $\mathrm{ft}$ foot \\ $\mathrm{ft} /$ day feet per day \\ FWS U.S. Fish and Wildlife Service \\ ha hectare \\ in inch \\ km kilometer \\ $\mathrm{m} \quad$ meter \\ $\mathrm{m}^{3} \quad$ cubic meter \\ $\mathrm{mBq} / \mathrm{m}^{2}$ sec millibecquerels per square meter per second \\ $\mathrm{mBq} / \mathrm{g}$ millibecquerels per gram \\ $\mathrm{mBq} / \mathrm{m}^{3} \quad$ millibecquerels per cubic meter \\ MCL maximum concentration limit \\ $\mathrm{mg} / \mathrm{L} \quad$ milligrams per liter \\ $\mathrm{mi} \quad$ mile \\ mrem millirem \\ mSv millisievert \\ $\mu \mathrm{R} / \mathrm{hr} \quad$ microroentgens per hour \\ NRC U.S. Nuclear Regulatory Commission \\ NRHP National Register of Historic Places \\ OHV off-highway vehicle \\ $\mathrm{Pb}-210 \quad$ lead-210 \\ $\mathrm{pCi} / \mathrm{g} \quad$ picocuries per gram \\ $\mathrm{pCi} / \mathrm{L}$ picocuries per liter \\ $\mathrm{pCi} / \mathrm{m}^{2} \mathrm{sec}$ picocuries per square meter per second \\ PMF \\ probable maximum flood \\ PMP \\ Ra-226 \\ probable maximum precipitation \\ Ra-228 radium-228 \\ TDS \\ Th-230 \\ TSP \\ U-238 \\ total dissolved solid \\ Thorium-230 \\ total suspended particulate \\ uranium-238
}




\section{LIST OF ACRONYMS AND ABBREVIATIONS (Concluded)}

\section{Acronym Definition}

$\mathrm{U}_{3} \mathrm{O}_{8}$

UMTRA

uranium oxide

UMTRCA

Uranium Mill Tailings Remedial Action

VP

$y d^{3}$

Uranium Mill Tailings Radiation Control Act

vicinity property

cubic yard 


\subsection{SUMMARY}

The purpose of this environmental assessment (EA) is to evaluate the environmental impacts resulting from remedial action at the Maybell uranium mill tailings site near Maybell, Colorado. A biological assessment (Attachment 1) and a floodplain/wetlands assessment (Attachment 2) are included as part of this EA. The following sections and attachments describe the proposed action, affected environment, and environmental impacts associated with the proposed remedial action, including impacts to threatened and endangered species listed or proposed for listing by the U.S. Fish and Wildlife Service (FWS).

\section{$1.1 \quad$ PROJECT SUMMARY}

The Maybell tailings site is 25 miles (mi) (40 kilometers [km]) west of the city of Craig, Colorado, in a rural area of Moffat County in northwestern Colorado (Figure 1.1). The designated site covers approximately 110 acres (ac) (45 hectares [ha]) and consists of a concave tailings pile and rubble from the demolition of the mill buildings, which are buried in the former mill area. The existing tailings pile is nearly rectangular with an average thickness of 20 feet (ft) (6 meters [m]) (Figure 1.2). Wind and surface water flow have dispersed contamination to areas surrounding the tailings pile and to Johnson Wash and Lay Creek (Figure 1.3). The total volume of contaminated materials at the Maybell site is 3.5 million cubic yards $\left(y d^{3}\right)\left(2.7\right.$ million cubic meters $\left.\left[\mathrm{m}^{3}\right]\right)$.

The proposed remedial action is to stabilize the contaminated materials at the existing tailings pile. The contaminated materials would be covered with a layer of compacted earth amended with 10 percent bentonite to inhibit radon emanation and water infiltration, a frost protection layer, a bedding layer, and a rock riprap cover. The above-ground disposal cell would cover 66 ac (27 ha) within the approximately 165 -ac (67-ha) final disposal site. The additional 100 ac (40 ha) of land beyond that required for the completed disposal cell is necessary to incorporate all disposal cell erosion protection features, which are discussed and illustrated in Section 2.2.1.

The majority of the land around the site is administered by the Bureau of Land Management (BLM). However, there is private land south, east, and west of the site. The northern portion of the designated site is on land administered by the BLM; the southern portion of the site is on private land (Figure 1.2). Umetco Minerals Corporation, a wholly owned subsidiary company of Union Carbide Corporation, holds the radioactive materials license for the designated site and continues as the operational controller. Umetco is not a landowner of the designated site. The state of Colorado has been authorized to perform land appraisals of the privately held properties associated with the proposed remedial action. Upon acquisition of the privately held properties, title shall then be transferred from the state of Colorado to the U.S. Department of Energy (DOE). Prior to initiation of the remedial action, the final disposal site area administered 


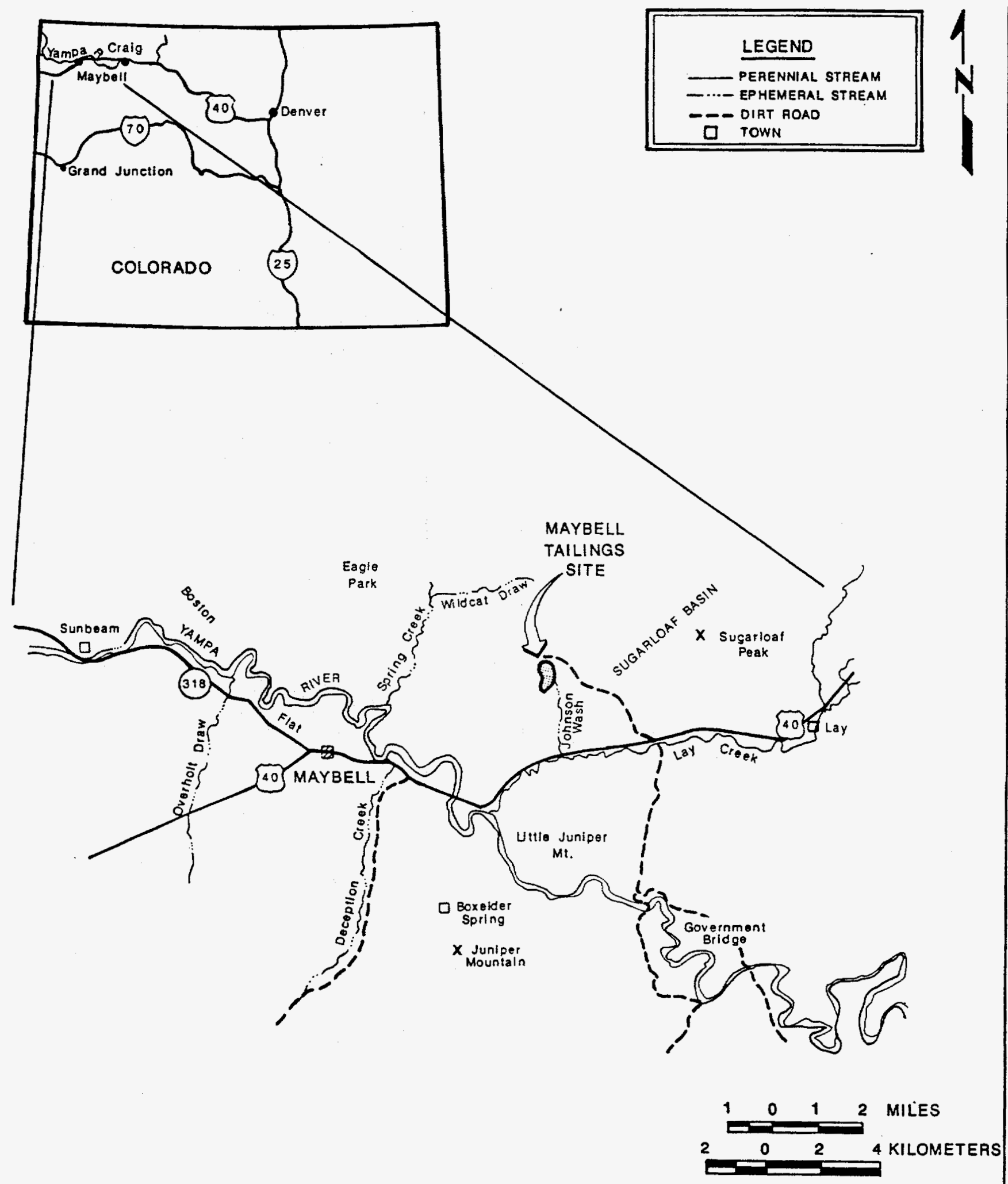

FIGURE 1.1

LOCATION MAP OF THE MAYBELL TAILINGS SITE NEAR MAYBELL, COLORADO 


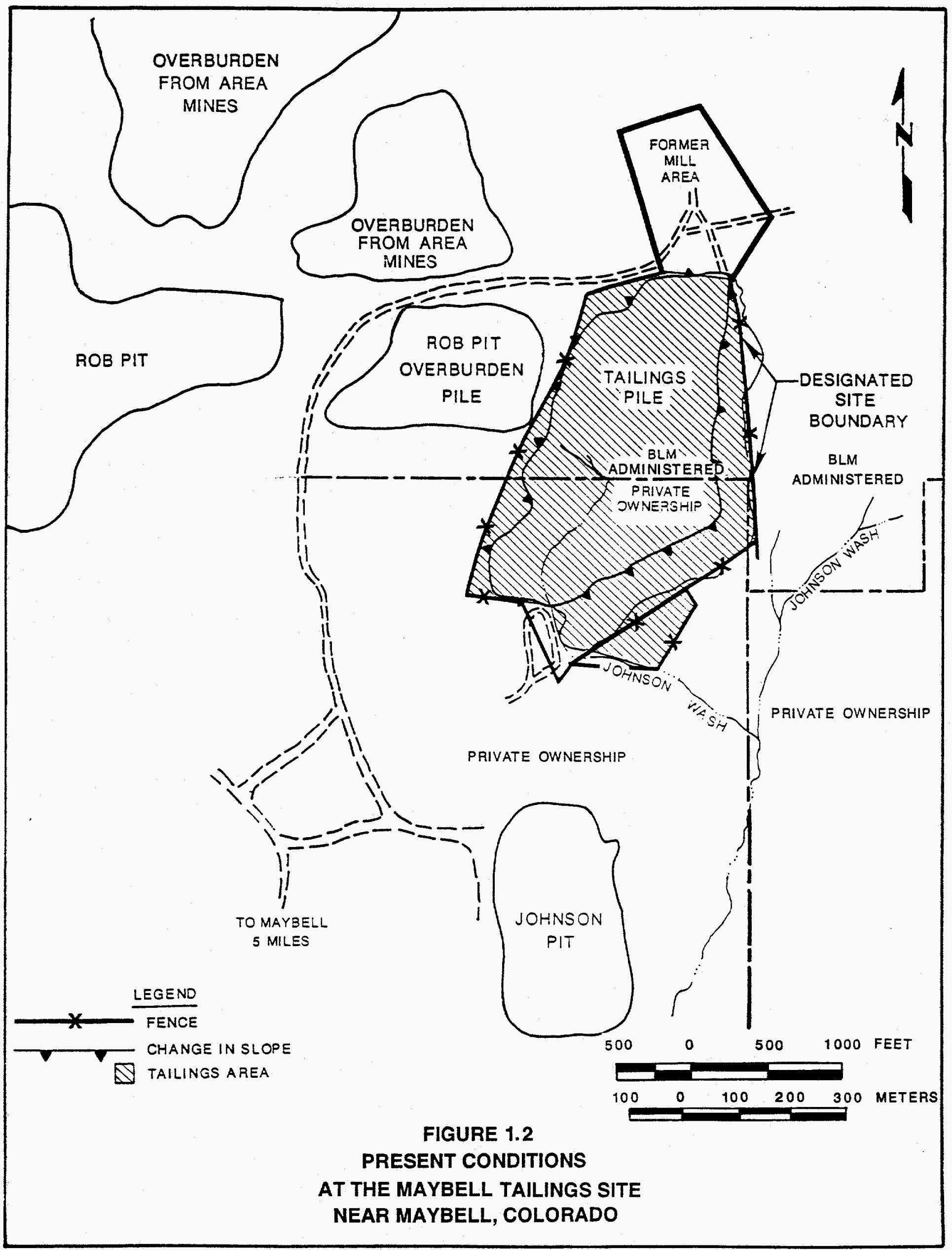




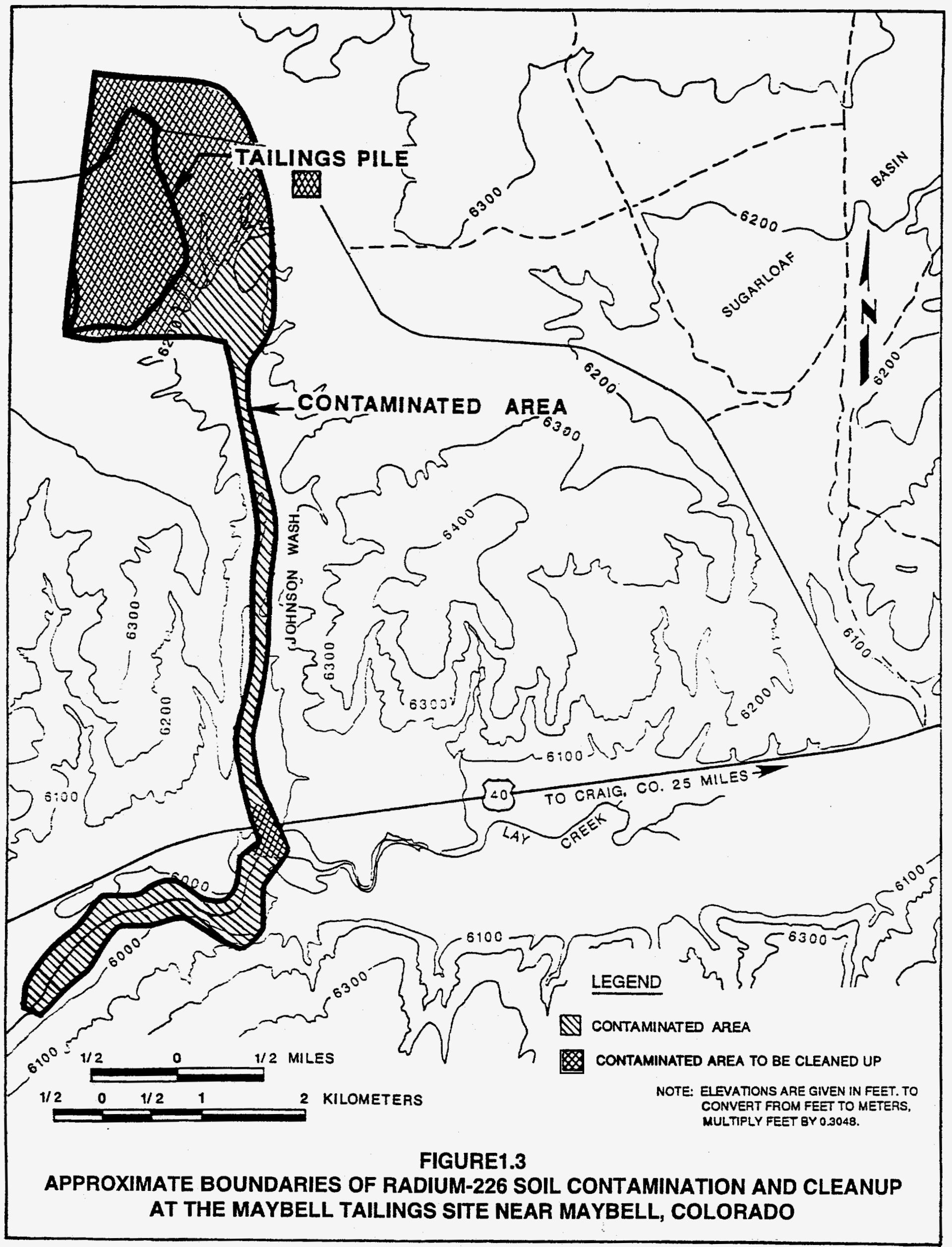


by the BLM would also be transferred to the United States of America under the administration of the DOE.

\subsection{IMPACT SUMMARY}

Access to the existing tailings pile is presently restricted by a fence. Upon completion of the remedial action, the final disposal site would cover approximately $165 \mathrm{ac}$ (67 ha). The site would be released to the federal government and restricted from future uses.

Adverse impacts of a temporary nature include the disturbance of $\mathbf{2 7 0}$ ac (110 ha) of land during remedial action; temporary loss of wildlife habitat and disturbance of area wildlife; generation of fugitive dust; and increases in outdoor noise levels related to construction activities at the site, along the haul roads, and at the proposed borrow locations. The disturbed areas would be recontoured and revegetated as soon as possible following remedial action.

Water required for remedial action would be used for compaction of consolidated materials, dust control, potable water, and vehicle washing. The total volume of water required during the 19-month remedial action period is estimated to be $19,100,000$ gallons $\left(72,000 \mathrm{~m}^{3}\right)$, or 59 acre-feet (ac-ft) (TAC, 1991). The average annual ac- $\mathrm{ft}$ of water to be required for construction purposes is estimated to be $29.5 \mathrm{ac}$-ft. Since some of the construction water may be obtained from the Yampa River, or from aquifers hydraulically connected to the Yampa River, this water depletion would result in a "may affect" determination for endangered fish of the Colorado River Basin by the FWS. Fish species subject to the FWS "may affect" determination include the Colorado squawfish, humpback chub, bonytail chub, and razorback sucker.

Under the Endangered Species Act of 1973 (PL 93-205), as amended, water depletion subject to a "may affect" determination requires formal consultation with the FWS. A mitigation plan consistent with the FWS "Recovery Implementation Program for Endangered Fish Species in the Upper Colorado River Basin" (FWS, 1987), would be implemented by the DOE. Mitigation for the water depletion and its impacts would be the one-time payment of $\$ 11.98$ (or the most current amount, which is adjusted annually for inflation) per acre-foot to the FWS by the DOE based on the average annual depletion of 29.5 ac-ft required for remedial action. These funds would be used to acquire water rights and otherwise support the recovery of the endangered fish of the Upper Colorado River Basin.

Off-highway vehicle (OHV) use of overburden piles and pits is permitted by the BLM. Recreational access to the Rob Pit overburden pile and the former mill site would be prohibited during the 19-month remedial action. These locations are within the proposed project area and access restriction would constitute a temporary negative impact to recreational users. 
Positive impacts are associated with implementation of the proposed remedial action. Cleanup of contaminated soils and reducing radon emanation from the tailings pile would result in a reduction in potential health effects. Construction activities would result in temporary increases in local expenditures for goods and services and in employment. 


\subsection{REMEDIAL ACTION ALTERNATIVES}

\subsection{THE NEED FOR REMEDIAL ACTION}

The uranium mill tailings at the abandoned uranium mill near Maybell, Colorado, are the residue of uranium ore processing operations and are finely ground rock. The principal potential hazard associated with the tailings is caused by the production of radon, a radioactive gas, from the radioactive decay of the radium contained within the tailings. Radon can move through the tailings into the air. Increased exposure to radon and its decay products over a long period of time increases the probability that health effects (i.e., cancers) may develop in persons living and working near the tailings.

Exposure to gamma radiation, the inhalation and ingestion of airborne radioactive particulates, the ingestion of contaminated food produced in the areas around the tailings, and the ingestion of surface water and ground water contaminated by the tailings pose lesser potential health hazards. If the tailings and the associated contaminated materials are not properly stabilized, processes such as wind and water erosion, or accidental removal of the materials by humans, could spread the contamination over a wider area and increase the potential public health hazards.

\subsubsection{Background}

On November 8, 1978, Congress passed the Uranium Mill Tailings Radiation Control Act (UMTRCA) (PL 95-604). Title I of the UMTRCA authorized the Secretary of Energy to enter into cooperative agreements with affected states or Indian tribes to clean up specified inactive sites contaminated with uranium mill tailings. Title I required the U.S. Environmental Protection Agency (EPA) to promulgate standards for these sites and defined the role of the U.S. Nuclear Regulatory Commission (NRC).

In developing these standards, the EPA determined that the primary objective for the control of residual radioactive materials was isolation and stabilization to prevent their unintentional misuse by people and dispersion by natural forces. A secondary objective was to reduce radon emissions, and a third objective was to eliminate significant public exposure to gamma radiation.

On September 3, 1985, the U.S. Tenth Circuit Court of Appeals remanded the portion of the standards relating to ground water. Proposed standards were issued for comment by the EPA on September 24, 1987 (52 FR 36000). Subpart $A$ of the proposed standards set forth the requirements for control of contaminant releases to ground water at the disposal sites (ground water protection). 


\subsubsection{The Maybell tailings site}

The Maybell tailings site is in Moffat County, Colorado, $25 \mathrm{mi}(40 \mathrm{~km}$ ) west of the city of Craig, Colorado (Figure 1.1). The closest town is Maybell (unincorporated), $5 \mathrm{mi}(8 \mathrm{~km})$ southwest of the site. No residents live near the tailings pile; the nearest residence is $2.9 \mathrm{mi}(4.7 \mathrm{~km})$ southwest of the site.

The Maybell tailings pile is located in Section 19. Township 7 North, Range 94 West, Sixth Principal Meridian. The former processing site is adjacent to the northern boundary of the tailings pile. The former processing site is located in parts of Sections 18 and 19, Township 7 North, Range 94 West, Sixth Principal Meridian (FBDU, 1981).

The Maybell site was established by the Trace Elements Corporation in 1955 and 1956. Umetco assumed control of the site, and in 1957 the mill began operation. Uranium ore was obtained from nearby open pit mines. During the 7 years of operation by Umetco, the mill processed approximately 2.6 million tons (2.4 million tonnes) of ore, having a grade of 0.098 percent uranium oxide $\left(\mathrm{U}_{3} \mathrm{O}_{8}\right)$. All concentrate produced was sold to the U.S. Atomic Energy Commission. Umetco dismantled the mill after it shut down in November 1964. Umetco began stabilizing the tailings in 1971 in accordance with Colorado regulations. Remaining features include the tailings pile, building foundations at the former processing site, nearby open pit mines, and overburden piles associated with the area mines.

Contaminated areas at the Maybell tailings site include the tailings pile and former processing site, windblown areas adjacent to the tailings pile, and contaminated areas along Johnson Wash and Lay Creek (Figure 1.3). The tailings pile contains approximately 2.8 million $\mathrm{yd}^{3}\left(2.1\right.$ million $\left.\mathrm{m}^{3}\right)$ of tailings. The former mill processing yard is located on the north side of the tailings pile and contains an estimated $20,000 \mathrm{yd}^{3}\left(15,000 \mathrm{~m}^{3}\right)$ of contaminated demolition debris from the former mill structures. Areas to the north, west, and south sides of the tailings pile contain approximately $244,000 \mathrm{yd}^{3}\left(187,000 \mathrm{~m}^{3}\right)$ of contaminated soils, including a raffinate pond adjacent to the southwest corner of the tailings pile. Wind dispersion has resulted in the contamination of areas around the tailings pile, primarily to the north and east. Approximately $240,000 \mathrm{yd}^{3}\left(184,000 \mathrm{~m}^{3}\right)$ of contaminated soils exist as a result of wind dispersion of contaminated materials. Surface water flow has dispersed contamination to drainage areas in Johnson Wash and Lay Creek.

Approximately $61,000 \mathrm{yd}^{3}\left(47,000 \mathrm{~m}^{3}\right)$ of contaminated materials are present in the two drainages. The total volume of contaminated materials is about 3.5 million $\mathrm{yd}^{3}\left(2.7\right.$ million $\left.\mathrm{m}^{3}\right)$.

\subsection{DESCRIPTION OF THE PROPOSED ACTION: STABILIZATION IN PLACE}

The proposed surface remediation action for the Maybell tailings site is to stabilize the tailings pile at its present location. The above-ground disposal cell design for the stabilization in place was developed to comply with the EPA 
standards (40 CFR 192 and 52 FR 36000). The completed disposal cell would contain the contaminated materials from the existing tailings pile, contamination from areas adjacent to the pile, and the windblown and waterborne areas of contamination.

This remedial action would include the cleanup of five vicinity properties (VP) (properties outside the designated site boundary that were contaminated by tailings materials). These properties are privately owned and are located adjacent to the site, and all five are windblown-and waterborne-contaminated land. If further data collection identifies additional VPs that would require remedial action, they would be remediated while the disposal cell is being constructed.

The northern portion of the site is on land administered by the BLM, the southern portion is on private land. Prior to any remedial action at the proposed disposal site (existing tailings pile location), a permanent jurisdiction transfer of BLM-administered land would be required to transfer administration of the disposal site to the DOE. Privately owned lands would be acquired by the state of Colorado. The state of Colorado would then transfer title of these lands to the DOE prior to initiation of the remedial action.

Figure 1.3 shows the approximate extent of contamination at the Maybell site. Not all of the contaminated areas along Johnson Wash and Lay Creek shown in Figure 1.3 would be cleaned up as part of the remedial action. The remedial action would result in the cleanup of two areas of contamination along Johnson Wash and near its confluence with Lay Creek. The two areas are shown in Figure 1.3, and are the result of waterborne contaminant transport. One area is located approximately $3000 \mathrm{ft}(900 \mathrm{~m})$ east of the tailings pile in Johnson Wash as it crosses under a county road. The second area is also in Johnson Wash and is located south of the tailings pile near the confluence of Johnson Wash and Lay Creek. Supplemental surface cleanup standards would be applied by the DOE to the majority of the contaminated areas of Johnson Wash and Lay Creek. With the exception of the two areas, the soils in Johnson Wash and Lay Creek only slightly exceed EPA standards (40 CFR 192) for radium-226 (Ra-226).

\subsubsection{Final conditions}

The completed, above-ground disposal cell would cover approximately 66 ac (27 ha) and would be triangular in shape, with a maximum length of $2650 \mathrm{ft}$ $(810 \mathrm{~m})$ and a maximum width of $1750 \mathrm{ft}(530 \mathrm{~m})$ (Figure 2.1). A gently sloping rock erosion protection apron will extend out $20 \mathrm{ft}(6 \mathrm{~m})$ from the above-ground sideslopes of the pile along the south and east toes. The apron would prevent headward erosion of gullies into the pile. The rock would be sized so that it is not eroded by flow from the probable maximum precipitation (PMP) storm runoff on the pile or flow from the probable maximum flood (PMF) around the pile. In addition, the site around the disposal cell would be graded to retard flow concentrations. 


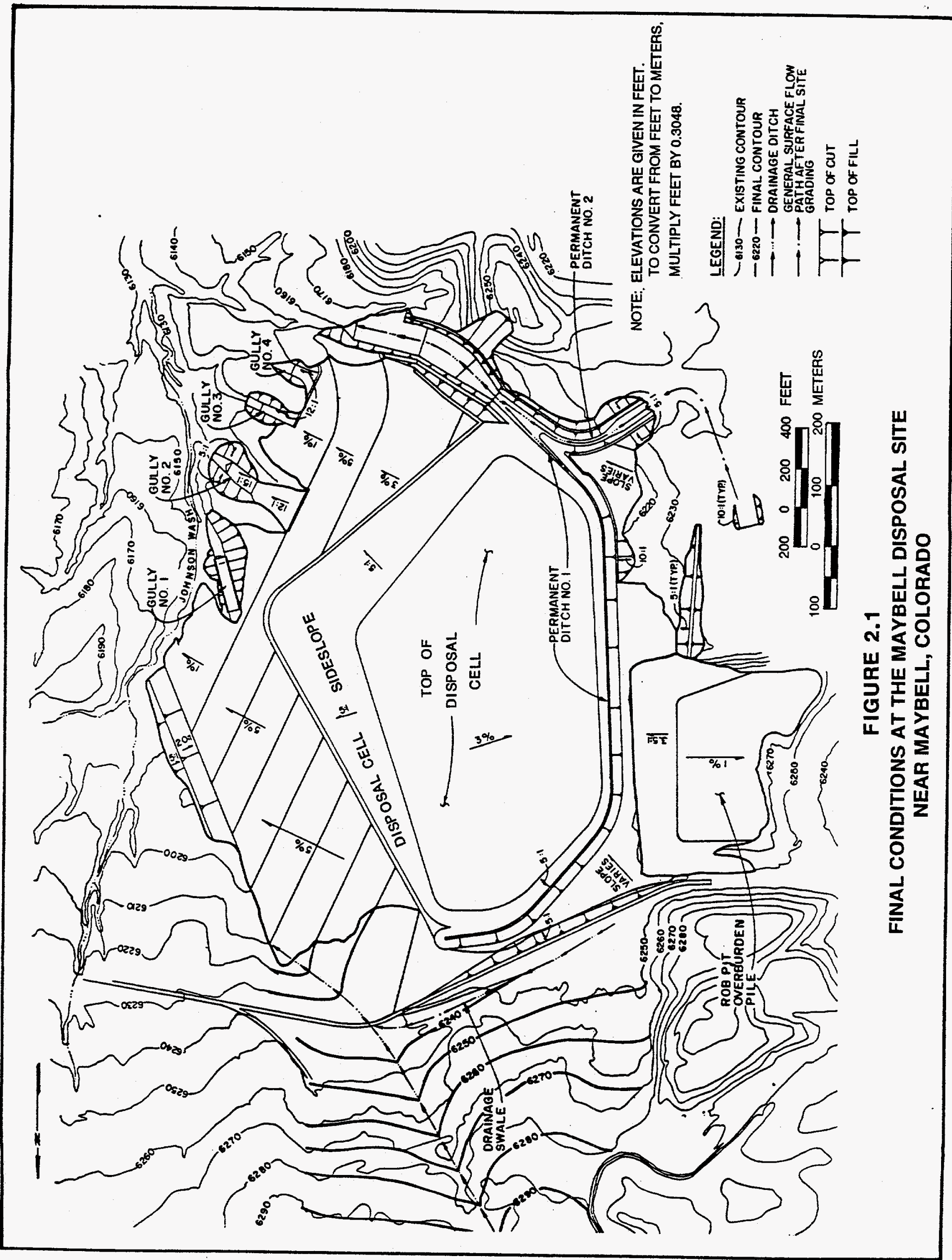


Contaminated materials stabilized in place at the present tailings pile location would be consolidated and contoured to form a disposal cell with maximum sideslopes of 20 percent (five horizontal to one vertical) and topslope of 3 percent. Materials from the mill area, windblown areas, and waterborne areas are less contaminated than the tailings, and would be placed on top of the tailings to reduce the required thickness of the radon barrier. The tailings and contaminated materials would be covered with a multi-layered cover. The top of the disposal cell would average $40 \mathrm{ft}(12 \mathrm{~m})$ above the surrounding terrain (Figure 2.2).

The topslope and sideslopes of the cell would be covered with a fine-grained radon barrier $1.5 \mathrm{ft}(0.5 \mathrm{~m})$ thick. The radon barrier would consist of compacted overburden materials from the Rob Pit overburden pile. The overburden materials would be amended with 10 percent bentonite by weight to provide a low-permeability layer that would reduce radon release to below performance standards and limit infiltration of precipitation through the tailings. Overlying the radon barrier would be a frost protection layer $4 \mathrm{ft}(1.2 \mathrm{~m})$ in thickness to prevent frost penetration from reaching the underlying radon barrier and potentially affecting its permeability. The uppermost portion of the cell cover would consist of a 6 -inch (in) (15.2 centimeter [cm]) gravel bedding layer overlain by an 8 -in-thick $(20.3 \mathrm{~cm})$ layer of riprap to prevent wind and water erosion and gully development. The outermost sideslope cover would consist of a 6-in-thick $(15.2 \mathrm{~cm})$ gravel bedding layer overlain by a 1 -ft-thick $(0.3 \mathrm{~m})$ layer of riprap. The bedding layer and riprap for the cover and sideslopes were designed to resist the PMP storm runoff peak discharges in accordance with standard design procedures described in the Uranium Mill Tailings Remedial Action (UMTRA) Technical Approach Document (DOE, 1989).

On the north and west sides of the stabilized pile a permanent ditch would be constructed around the disposal cell to divert flow away from the cell. The locations and extents of the two permanent ditches (Nos. 1 and 2) are shown in Figure 2.1. The rock designed for the erosion protection layer for the two ditches will be sized so that it is not eroded by flow from the PMP storm runoff or the PMF.

Key trenches designed to be collapsible and provide a stable slope against scours are provided at the outlet for Permanent Ditch No. 1 and the gullies along Johnson Wash, the inlet for Permanent Ditch No. 2, and the apron along the eastern and southern toes of the disposal cell. Additional erosion protection (Figure 2.1) for the stabilized pile would be implemented in the area between the pile and Johnson Wash. This area would be regraded and the gullies protected with rock riprap.

The final restricted area would cover approximately 165 ac (67 ha). The perimeter of the area would be marked with warning signs, boundary markers, and survey monuments. The areas surrounding the disposal cell that were disturbed by the remedial action would be backfilled as required, graded to control surface drainage, and revegetated. 


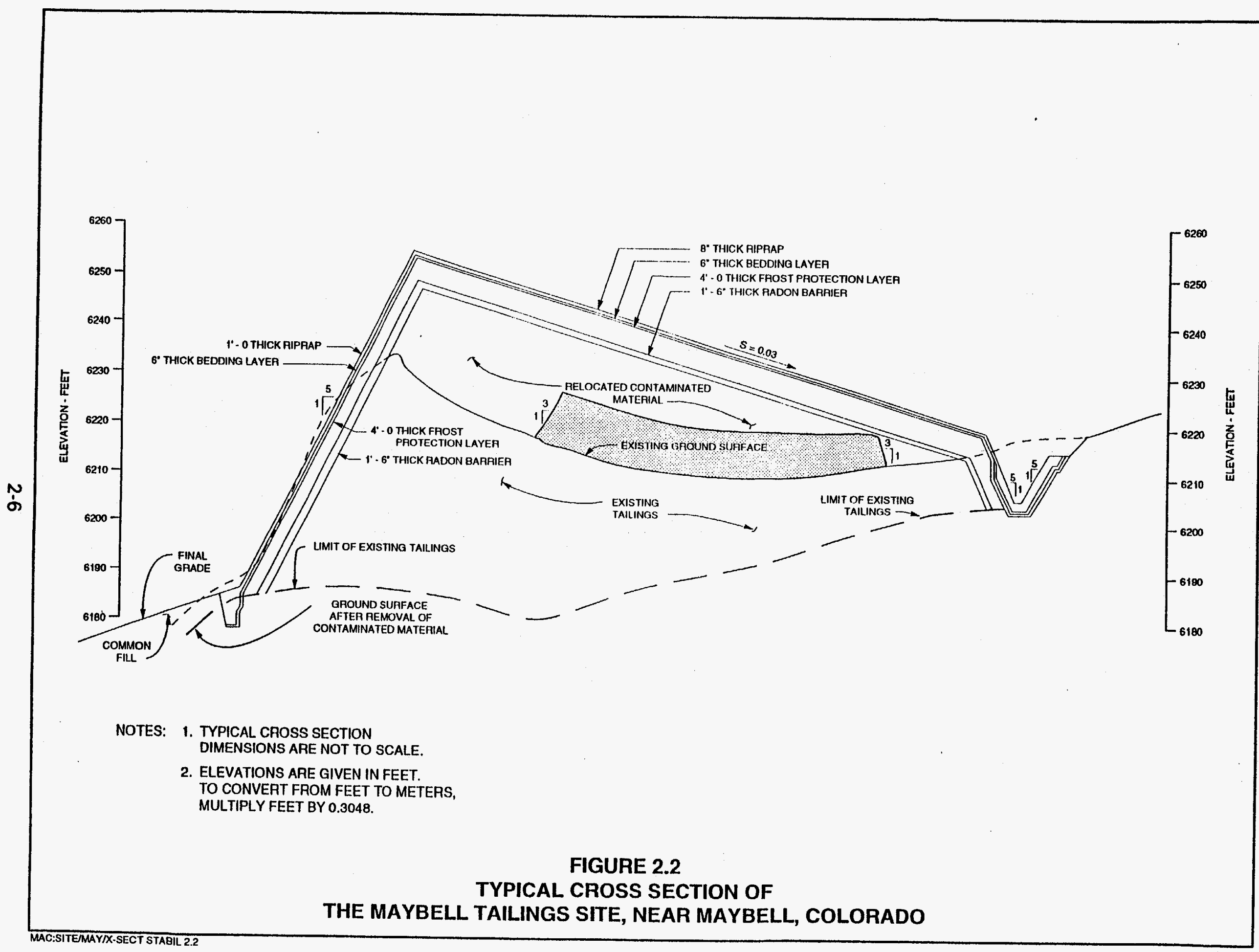


2.2.2 Implementation of supplemental standards for surface cleanup at the Maybell site

Figure 1.3 shows areas along Johnson Wash and Lay Creek that have been contaminated by waterborne dispersion of contaminated materials. Section $\mathbf{2 . 2}$ describes two areas that will be cleaned up as part of the remedial action. With the exception of the two areas, the soils in Johnson Wash and Lay Creek only slightly exceed EPA standards (40 CFR Part 192) for Ra-226. Following cleanup of the two areas along Johnson Wash and at the confluence of Johnson Wash and Lay Creek, the estimated average remaining Ra-226 and Th-230 contamination levels would be below the EPA cleanup standard of $\mathbf{5 . 0}$ picocuries per gram ( $\mathrm{pCi} / \mathrm{g}$ ) (185 millibecquerels per gram $[\mathrm{mBq} / \mathrm{g}$ ) above background (40 CFR Part 192).

Subpart C of 40 CFR 192.21 (b) would be followed by the DOE regarding the proposed use of supplemental surface cleanup standards for the majority of contaminated portions of Johnson Wash and Lay Creek. Contaminated materials in the majority of Johnson Wash and Lay Creek would not be excavated and placed in the disposal cell. Cleanup would occur at the two areas of elevated contamination described in Section 2.2. Contaminated material from these two areas would be excavated and placed in the disposal cell. Justification for the DOE's proposed use of supplemental surface cleanup standards for most of Johnson Wash and Lay Creek is based on a combination of ecological, radiological, and engineering criteria summarized as follows:

- Environmental harm to riparian and wetland areas.

- Low radon flux from existing contaminants.

- Low predicted effects from human consumption of cattle that graze in Johnson Wash.

- Detrimental effects on geomorphic stability in Johnson Wash.

- Costly excavation and diversion of Lay Creek.

Approximately 9 ac ( $3.6 \mathrm{ha})$ of wetlands occur in the contaminated section of Johnson Wash, while 22 ac $(9 \mathrm{ha})$ of wetlands occur in the contaminated section of Lay Creek (Opdycke, 1986). Application of supplemental surface cleanup standards would result in no disruption of these 31 ac (13 ha) of wetlands habitat.

Existing radon emissions from contaminated soils in Johnson Wash and Lay Creek contribute very little to excess health effects from the tailings site. Following remediation of the two "hot spots," the predicted radon flux from these areas is 10.0 picocuries per square meter per second $\left(\mathrm{pCi} / \mathrm{m}^{2} \mathrm{sec}\right)$ $\left(0.37\right.$ becquerels per square meter per second $\left.\left[\mathrm{Bq} / \mathrm{m}^{2} \mathrm{sec}\right]\right)$ and $8.6 \mathrm{pCi} / \mathrm{m}^{2} \mathrm{sec}$ 
$\left(0.32 \mathrm{~Bq} / \mathrm{m}^{2} \mathrm{sec}\right)$, respectively, which is less than the EPA standard of $20 \mathrm{pCi} / \mathrm{m}^{2} \mathrm{sec}\left(0.74 \mathrm{~Bq} / \mathrm{m}^{2} \mathrm{sec}\right)$ (40 CFR 192.02(2)(i)).

\subsubsection{Implementation of a narrative supplemental standard for ground water} protection at the Maybell site

The DOE is proposing a narrative supplemental standard for protection of ground water at the Maybell site. To achieve compliance with the proposed EPA ground water protection and cleanup standards (52 FR 36000), the DOE has evaluated the standards based upon ground water characteristics at the Maybell site. Key elements of the evaluation are described below.

\section{Demonstration of compliance with the proposed EPA ground water protection and cleanup standards (52 FR 36000)}

The DOE has characterized the hydrogeologic units, hydraulic and transport properties, water quality, geochemical conditions, and ground water use at the Maybell site. The existing tailings pile is underlain by the Browns Park Formation. The principal aquifer system (uppermost aquifer) is the upper sandstone unit of the Browns Park Formation. The supplemental ground water standard proposed by the DOE applies to the Browns Park Formation aquifer. Unconfined ground water occurs within this formation at depths ranging from $35 \mathrm{ft}$ to greater than $300 \mathrm{ft}(11 \mathrm{~m}$ to greater than $90 \mathrm{~m})$ beneath the ground surface. Ground water in the tailings pile vicinity flows in a southwesterly direction.

Design parameters of the proposed disposal cell have been evaluated in conjunction with the hydrogeologic and geochemical characteristics of the Maybell site. The consideration of supplemental ground water standards has included long-term seepage, transient drainage, and geochemical attenuation evaluations. Reducing geochemical conditions that are naturally occurring exist within the Browns Park Formation aquifer in the vicinity of the Maybell tailings site. These conditions have prevented contamination of ground water downgradient of the existing tailings pile.

The DOE is not proposing numerical concentration limits for hazardous constituents of concern or a point of compliance for the Maybell site. Background ground water quality in the Browns Park Formation aquifer is highly variable. Concentrations of some of the hazardous constituents of concern identified in the ground water at the Maybell site vary from below laboratory method reporting limits to several orders of magnitude above the proposed EPA ground water protection and cleanup standards. In addition, the ground water in the Browns Park Formation downgradient of the affected area is not an historic or current source of drinking water.

Naturally occurring reducing geochemical conditions exist within the Browns Park Formation aquifer in the vicinity of the Maybell tailings site. These 
conditions have prevented contamination of ground water resulting from the tailings pile and other site activities downgradient of the existing tailings pile.

A performance assessment (DOE, 1994) based on the site evaluations conducted to date indicates that the proposed remedial action would allow for compliance with the proposed EPA ground water protection standards (52 FR 36000 ). The proposed remedial action would achieve compliance because 1) no ground water contamination exists downgradient of the tailings pile from milling operations that occurred at the site, 2) favorable geochemical conditions would result in precipitation or attenuation of hazardous constituents of concern, 3) the disposal cell design would minimize infiltration of water, and 4) transient drainage would be minimized by controlling the moisture content during placement of materials and limiting water used in construction of the disposal cell.

\subsubsection{Borrow sites}

Construction of the above-ground disposal cell would require the use of borrow materials (earth, gravel, and rock). Borrow sites proposed for use include the Rob Pit overburden pile, the Maybell gravel source, the Juniper Mountain Limestone Quarry (also known as the Don Steele Limestone Quarry), and the Craig Basalt Quarry (also known as the Don Steele Basalt Quarry) (Figure 2.3).

The Rob Pit overburden pile borrow site is on land administered by the BLM and is located adjacent to the western edge of the existing tailings site. This overburden material is derived from mining activities at Rob Pit which is located west of the overburden pile (see Figure 1.2). This borrow site is proposed as the source of material for construction of the disposal cell radon barrier and frost protection layer, and for use in final site grading. An estimated total volume of $759,000 \mathrm{yd}^{3}\left(580,000 \mathrm{~m}^{3}\right)$ of material from the Rob Pit overburden pile will be utilized during construction.

The Maybell gravel source borrow site is along the Yampa River $1 \mathrm{mi}(1.6 \mathrm{~km})$ northeast of Maybell (Figure 2.3) and is $4.5 \mathrm{mi}(7.2 \mathrm{~km})$ west of the site. This borrow site is proposed as a source of gravel for construction of the disposal cell bedding layer, Types A and B riprap material for erosion protection for the embankment cover and armoring of permanent drainage ditches and gullies, and as an aggregate base for construction of access control facilities. An estimated total volume of $175,000 \mathrm{yd}^{3}\left(134,000 \mathrm{~m}^{3}\right)$ of materials will be required from the Maybell gravel source borrow site.

Large rock will be used as riprap for erosion protection of the disposal cell and for armoring of permanent drainage ditches and gullies. The proposed sources of this rock are the Juniper Mountain Limestone Quarry and the Craig Basalt Quarry. Both of these sites are existing quarry operations. The Juniper Mountain Limestone Quarry is $2.5 \mathrm{road} \mathrm{mi}(4 \mathrm{~km})$ south of U.S. Highway 40 and is about 7.2 road $\mathrm{mi}(11.6 \mathrm{~km})$ from the tailings site. The Craig Basalt Quarry is located approximately 9 road mi $(14.5 \mathrm{~km})$ southeast of Craig, Colorado, and 


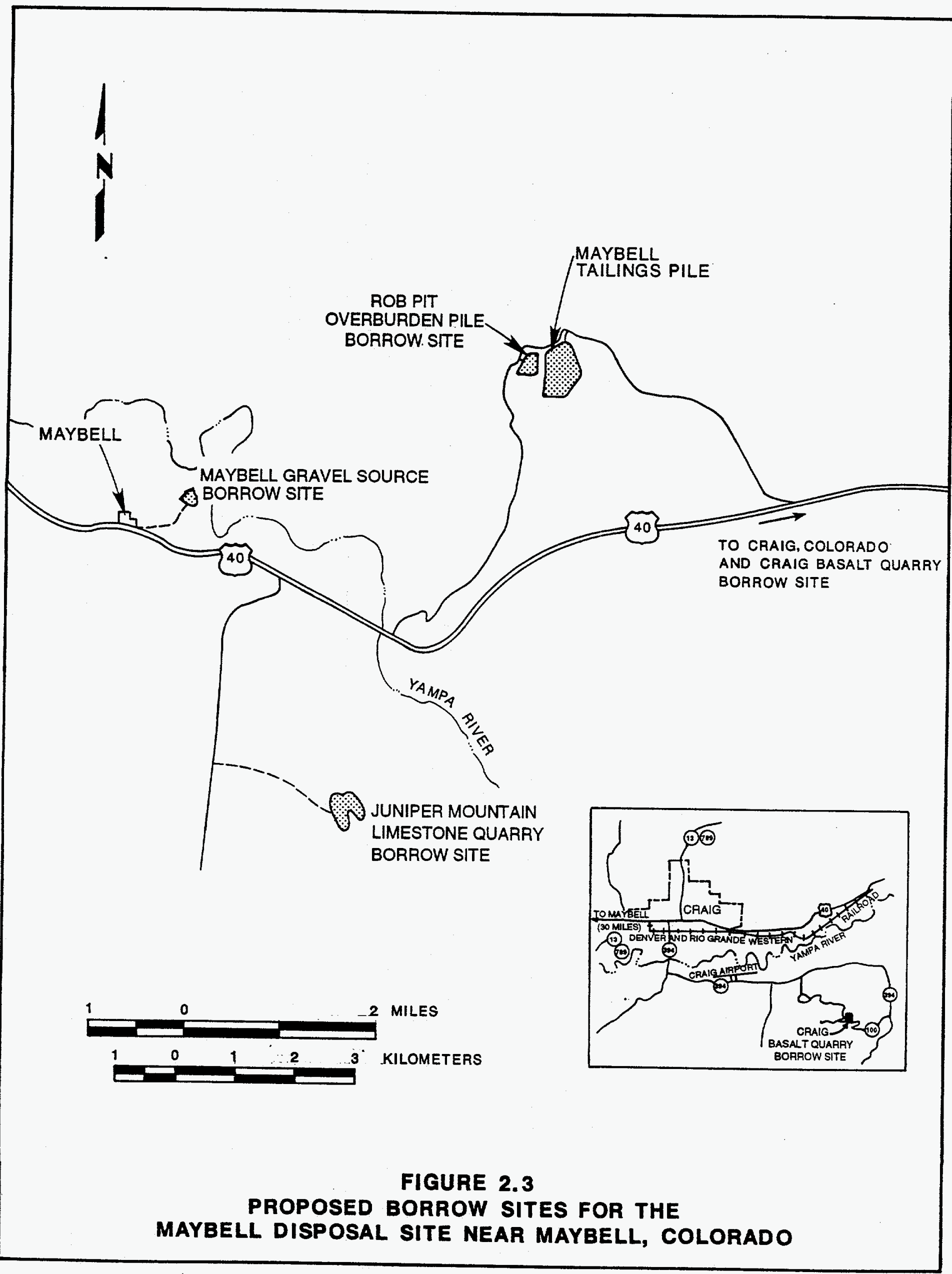


approximately 30 road $\mathrm{mi}(48 \mathrm{~km}$ ) from the tailings pile (Figure 2.3). An estimated total volume of $87,000 \mathrm{yd}^{3}\left(67,000 \mathrm{~m}^{3}\right)$ of rock would be obtained from these two sources.

The borrow sites included in this EA were selected as the source of the necessary borrow materials for impacts analysis purposes. Although the borrow sites identified would likely be used during remedial action, the borrow sites selected may change during the final design. However, the impacts identified for borrow sites included in this EA are conservative and represent a realistic upper limit on the severity of the impacts that may occur.

Assuming that the proposed borrow sites are used for the remedial action, a Free Use Permit would be obtained from the BLM for both the Craig Basalt Quarry and the Juniper Mountain Limestone Quarry.

\subsection{ALTERNATIVES TO THE PROPOSED ACTION}

\subsubsection{No action}

The no action alternative consists of taking no steps toward remedial action at the tailings site or areas of windblown/waterborne contamination. The tailings pile would remain in its present condition and would continue to be subject to dispersion by wind and water erosion and unintentional use by humans. The BLM could deny approval for the currently proposed action and could deny all permits associated with using the identified sites and roads on BLMadministered land; thus, no public lands would be disturbed. The contaminated materials and debris would remain where they are currently located until the DOE could identify another suitable disposal site. The selection of this alternative would not be consistent with the intent of Congress in the UMTRCA (PL 95-604) and would not result in the DOE's compliance with the EPA standards in 40 CFR Part 192 and 52 FR 36000.

\subsubsection{Disposal at the Johnson Pit site}

Johnson Pit (Figure 1.2) was considered as an alternate disposal site, since it is close to the tailings pile and is large enough, with some excavation, to hold the tailings and other contaminated materials. However, this would not be a completely below-grade disposal. A multicomponent cover, for radon attenuation and erosion protection, similar to the one described in the proposed action would be required. The main disadvantage to this option would be the placement of the contaminated materials closer to ground water, as compared to the proposed remedial action, with the bottom of the cell approximately $10 \mathrm{ft}$ above the water table. This could result in ground water contamination in an area not impacted by the existing tailings pile. There would also be less thickness of unsaturated soils for attenuation of contaminants. Since the natural hydrogeologic system has been disrupted because of mining activities, a thin layer of unsaturated soils may not provide adequate attenuation of contaminants, which could result in increased mobility of contaminants in 
ground water. If the bottom of the cell were raised, the volume of the pit would not be sufficient to hold the contaminated materials. Another disadvantage to this option would be the increased cost of the remedial action related to the excavation, transportation, and placement of the contaminated materials in the pit. There would also be increased site restoration costs and a longer construction period. For these reasons, the Johnson Pit alternative was eliminated from further consideration.

\subsubsection{Reprocessing the tailings}

Because the Maybell tailings contain residual uranium and vanadium, the feasibility of reprocessing the tailings for these metals was evaluated (FBDU, 1981). Three alternative reprocessing methods were considered: 1) heap leaching, 2) treatment at an existing mill, and 3) reprocessing at a new conventional mill. The analysis estimated that the capital and operating costs for reprocessing the tailings would be approximately $\$ 870$ (1981 dollars) per pound of $\mathrm{U}_{3} \mathrm{O}_{8}$ produced. Based on this analysis, recovery of $\mathrm{U}_{3} \mathrm{O}_{8}$ would not be cost effective because the current market price for $U_{3} \mathrm{O}_{8}$ is below $\$ 10$ per pound.

Furthermore, reprocessing of the tailings would not reduce the radium content of the tailings. Since radioactive decay of radium is the source of radon gas, there would be no reduction of the hazard from radon and radon progeny; hence, the reprocessed tailings would still require remedial action to meet the EPA ground water protection and cleanup standards. Reprocessing was therefore eliminated from further consideration.

\subsubsection{Disposal at the Umetco Minerals Corporation site}

Evaluation of the collocation alternative began in October 1993. This alternative would combine the disposal of the Maybell tailings with the uraniumcontaminated material at the nearby Umetco Minerals Corporation site. All contaminated material from the Maybell site would be relocated to a single disposal cell constructed at the Umetco site. The Umetco site is a former heap leach facility located approximately $1 \mathrm{mi}(1.6 \mathrm{~km})$ west of the Maybell site. Remedial action plans by Umetco would stabilize its heap leach pile in place. The cover proposed by Umetco is a multicomponent cover for radon attenuation and erosion protection similar in design to an UMTRA cell.

Under the proposed stabilization-in-place remedial action for the Maybell site, approximately $550,000 \mathrm{yd}^{3}\left(420,000 \mathrm{~m}^{3}\right)$ of mostly windblown and waterborne materials would be excavated and stabilized on the existing tailings pile. The volume of contaminated materials at Maybell is estimated to be 3.5 million $\mathrm{yd}^{3}$ ( 2.7 million $\mathrm{m}^{3}$ ), but does not consider subpile contamination. Under a collocation option, this volume of material, together with an additional volume of subpile materials, would have to be relocated to the Umetco site; total volume is conservatively estimated to be approximately 3.5 to 4.0 million yd ${ }^{3}$ (2.7 to 3.1 million $\mathrm{m}^{3}$ ). 
The primary disadvantage of the collocation alternative is that it would not be cost-effective to relocate all of the Maybell site contaminated materials to the Umetco site. The current cost estimate for the Maybell site proposed remedial action is approximately $\$ 12$ million. Preliminary estimates of the cost to relocate all of the Maybell site contaminated materials to Umetco for disposal would be approximately $\$ 24$ to $\$ 28$ million. This amount does not include construction management costs or the cost of restoration, regrading, and cleanup of vicinity property areas at the Maybell site. Based on costeffectiveness, the collocation alternative was eliminated from further consideration. 


\subsection{AFFECTED ENVIRONMENT}

\section{CLIMATE AND AIR QUALITY}

The Maybell site has a semiarid continental climate that can be characterized as dry and sunny with little precipitation, warm summers and cold winters, and large diurnal to nocturnal and seasonal temperature changes. The nearest weather station is in the city of Craig, Colorado, $25 \mathrm{mi}(40 \mathrm{~km})$ east of the site. The elevation and topographic relief of the Craig, Colorado, weather station $(6285 \mathrm{ft})(1915 \mathrm{~m})$ are similar to the tailings pile $(6200 \mathrm{ft})(1890 \mathrm{~m})$, and therefore representative of conditions at the tailings pile.

The climate at Craig, Colorado, is semiarid, with a mean annual precipitation of 13.29 in (34 cm) per year (NOAA, 1977). The annual precipitation data were for the 23-year period from 1951 through 1973. Precipitation at the site occurs as both rain and snow with snow being the predominant form. The amount of precipitation received monthly was relatively well distributed with the minimum occurring in March $(0.81 \mathrm{in})(2.1 \mathrm{~cm})$ and the maximum in August (1.5 in) $(3.8 \mathrm{~cm})$. The average annual snowfall was 80.6 in $(205 \mathrm{~cm})$, with December receiving the highest average snowfall of 18.6 in $(47 \mathrm{~cm})$.

The mean annual temperature at Craig, Colorado, for the same 23-year period, was 42 degrees Fahrenheit $\left({ }^{\circ} \mathrm{F}\right)\left(5.5\right.$ degrees Centigrade $\left.\left[{ }^{\circ} \mathrm{C}\right]\right)$, with a range from -45 to $+99^{\circ} \mathrm{F}\left(-43\right.$ to $\left.+37^{\circ} \mathrm{C}\right)$. The mean temperature per month varied from $18^{\circ} \mathrm{F}\left(-8^{\circ} \mathrm{C}\right)$ in January to $67^{\circ} \mathrm{F}\left(19^{\circ} \mathrm{C}\right)$ in July. December, January, and February were the coldest months with an average temperature of 18 to $20^{\circ} \mathrm{F}$ $\left(-8\right.$ to $\left.-7^{\circ} \mathrm{C}\right)$. The length of the freezing season was approximately 197 days. For the 23-year period from 1951 through 1973, June, July, and August were the warmest months with an average temperature of 60 to $67^{\circ} \mathrm{F}\left(16\right.$ to $\left.19^{\circ} \mathrm{C}\right)$. Temperature extremes for the 23-year period consisted of a low of minus $45^{\circ} \mathrm{F}$ $\left(-43^{\circ} \mathrm{C}\right)$ recorded in January 1963 , and a high of $99^{\circ} \mathrm{F}\left(37^{\circ} \mathrm{C}\right)$ recorded in July 1968. The temperature equaled or exceeded $90^{\circ} \mathrm{F}\left(32^{\circ} \mathrm{C}\right)$ on only a few days (NOAA, 1977).

Surface wind data from Craig, Colorado, indicate that the most prevalent wind direction is from the west-southwest. Winds blow 21 percent of the time from the west-southwest and 15 percent of the time from the west. Winds of less than 3 miles per hour ( 1.4 kilometers per hour), or calm conditions, occur 6 percent of the time. The windiest month is June and the calmest month is December (FBDU and SNL, 1982).

The state of Colorado maintained an Air Quality Monitoring station in Craig that ceased operation in 1987. Therefore, current air quality data are not available for the Maybell site area. However, all pollutant levels measured in Craig were below the applicable EPA standards. Also, it is expected that the historical and present pollutant levels at the Maybell site would be less than at Craig given the rural nature of the site. 


\subsection{GEOLOGY, MINERAL RESOURCES, AND SOILS}

\subsubsection{Geology}

The Maybell site is in the Sand Wash Basin subprovince of the Wyoming Basin physiographic province. The basin is characterized by low relief, meandering streams, and sparse to moderate vegetation.

The site lies in a small valley bounded on the north and south by conifer-covered ridges. Johnson Wash, an ephemeral stream, drains the immediate area of the site in the shallow, low-relief subbasin. The outlet for the wash is through a notch in the south ridge where the superimposed drainage has incised a narrow valley to connect to the regional drainage, Lay Creek. Lay Creek is a perennial, meandering stream that joins with the Yampa River $5 \mathrm{mi}(8 \mathrm{~km})$ southwest of the Maybell tailings pile.

The bedrock that underlies the site is the Browns Park Formation, approximately 800 to $900 \mathrm{ft}(240$ to $270 \mathrm{~m})$ thick. Beneath the Browns Park Formation sandstone is Cretaceous-aged Mancos Shale that is over $5000 \mathrm{ft}(1500 \mathrm{~m})$ thick. The major fault systems within the site region are all considered seismically noncapable. Primary faults with large displacements and secondary faults with small displacements occur within the site area.

Secondary faults are projected to occur below the present tailings site, and many other small displacement faults are expected to be hidden below the soilalluvium with the area. Seismicity in the region is random and not assignable to any specific fault. Earthquake data indicate a maximum instrumental record of local magnitude 5.7 at a distance of $51 \mathrm{mi}(82 \mathrm{~km})$ within a $125-\mathrm{mi}(200-\mathrm{km})$ site radius.

\subsubsection{Soils}

Locally, the Johnson Wash subbasin contains Quaternary deposits of loess-type soils ranging from 2 to $4 \mathrm{ft}(0.6$ to $1.2 \mathrm{~m})$ thick in the site area to $20 \mathrm{ft}(6.1 \mathrm{~m})$ thick in the lower central part of the drainage. The ridges bounding the site area have a very thin soil cover and consist of Browns Park sandstone that locally is made resistant by moderate cementation.

\subsubsection{Mineral resources}

Economically important mineral resources in the site region include uranium and vanadium ores, coal, oil and gas, oil shale, and other metallic and nonmetallic minerals including gold, silver, copper, gypsum, and potash (Steele et al., 1979). Of all the region's economic mineral resources, only uranium has been significantly exploited in the immediate site area and ore bodies are still present. Uranium mining has not taken place in this area in recent years. Coal-bearing formations do not occur in the site area. The BLM offered one oil and gas lease for competitive sale on August 12, 1993. The competitive oil and gas lease, 
COC 55272, includes the east one-half, northeast one-fourth, southeast onefourth, and southwest one-fourth of Section 19, Township 7 North, Range 94 west. No other oil and gas leases are within the actual affected area. There are 13 unpatented mill site claims in the vicinity of the proposed project area. At present, no ongoing mineral development activities are occurring at or around the site (Husband, 1993).

\subsection{WATER RESOURCES}

\subsubsection{Surface water}

The Maybell tailings site is drained by Johnson Wash, an ephemeral stream that is tributary to Lay Creek. Lay Creek, a perennial stream, is tributary to the Yampa River; its confluence with the Yampa River is about $5 \mathrm{mi}(8 \mathrm{~km})$ southwest of the Maybell tailings pile. Wetlands occur in Johnson Wash and Lay Creek; they are discussed in Section 3.4.1 of this EA and in Attachment 2, Floodplain/Wetlands Assessment. The only permanent surface water feature near the tailings site is in the bottom of Rob Pit (Figure 3.1). A water pipeline is present in Rob Pit. The pipeline extends from the water at the bottom of Rob Pit to a pump located outside of the pit.

The Maybell tailings site is approximately $200 \mathrm{ft}(60 \mathrm{~m})$ higher in elevation than the Lay Creek floodplain at its confluence with Johnson Wash; therefore, flooding in either Lay Creek or the Yampa River will not impact the tailings site. Johnson Wash, an ephemeral stream which remains dry except during major runoff events, is eroding northward, approximately parallel to and 200 to $500 \mathrm{ft}$ $(60$ to $150 \mathrm{~m}$ ) east of the tailings pile. Runoff from the watershed upstream of the pile (approximately 220 ac [89 ha]) and from the pile itself flows on either side of the pile to the two arms of Johnson Wash. No well-defined channels exist upstream of the tailings pile.

Surface waters in the site area have been sampled and the results compared to EPA secondary maximum contaminant levels for public water systems listed in 40 CFR 143.3. Locations sampled include two in Rob Pit, two locations along Johnson Wash where standing water was present, and three locations in Lay Creek. The locations in Lay Creek lie at its confluence with Johnson Wash, and upstream and downstream of the confluence with Johnson Wash (Figure 3.1). The samples were analyzed for selected ions which included chloride, sodium, sulfate, and total dissolved solids (TDS) and $\mathrm{pH}$. The results are summarized in Table 3.1. The samples were also analyzed for radionuclide concentrations which are discussed in Section 3.5, "Radiation."

The EPA secondary drinking water standards for sulfate and TDS were exceeded at all surface water locations sampled. All chloride values reported were below the EPA secondary drinking water standards of $40 \mathrm{CFR}$ 143.3. All pH values reported, except one sampling event at location 703 in Rob Pit, were within the EPA secondary drinking water standard range (40 CFR 143). Median chloride and sodium values from all three Lay Creek locations were greater than median 


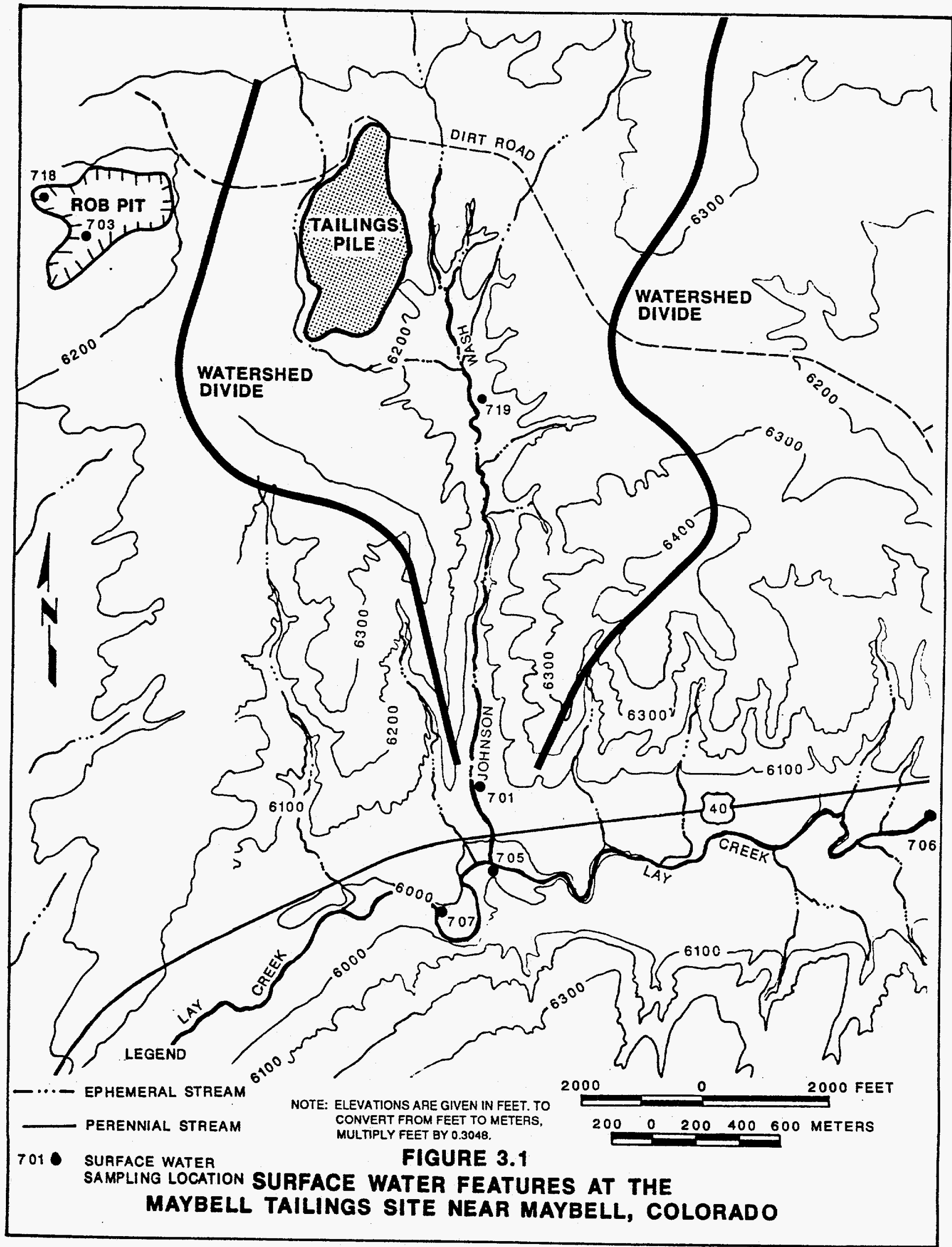


Table 3.1 Concentrations of selected major ions in surface water samples collected near the Maybell tailings site near Maybell, Colorado ${ }^{\mathrm{a}, \mathrm{b}}$

\begin{tabular}{|c|c|c|c|c|c|c|c|c|}
\hline \multirow[b]{4}{*}{ Paramater } & \multicolumn{7}{|c|}{ Sampling location and site identification number ${ }^{c}$} & \multirow{4}{*}{$\begin{array}{c}\text { Secondary } \\
\text { drinking } \\
\text { water } \\
\text { standards }\end{array}$} \\
\hline & & & & & \multicolumn{3}{|c|}{ Lay Creek ${ }^{h}$} & \\
\hline & \multicolumn{2}{|c|}{ Rob Pit } & \multicolumn{2}{|c|}{ Johnson Wash } & Upstream & Confluence & Downstroam & \\
\hline & $703^{d}$ & $718^{\circ}$ & $701^{\dagger}$ & $719^{9}$ & 706 & 705 & 707 & \\
\hline Chloride & 15 & 25 & 44 & 40 & 105 & 131 & 133 & 250 \\
\hline $\mathrm{pH}$ & $6.3-8.06$ & $8.16-8.39$ & 7.26 & $7.2-7.65$ & $7.85-8.32$ & $7.8-8.05$ & $7.93-8.12$ & $6.5-8.5$ \\
\hline Sodium & 57 & 36 & 160 & 73 & 451 & 482 & 503 & NA \\
\hline Sulfate & 1069 & 1825 & 1040 & 1125 & 1263 & 1349 & 1411 & 250 \\
\hline $\begin{array}{l}\text { Total dissolved } \\
\text { solids }\end{array}$ & 1647 & 2660 & 1840 & 2060 & 2330 & 2498 & 2505 & 500 \\
\hline
\end{tabular}

solids

${ }^{a}$ All results reported in milligrams per liter $(\mathrm{mg} / \mathrm{L})$, except $\mathrm{pH}$ values which are reported in standard units.

${ }^{\text {b}}$ Surface water data from samples collected August 31, 1986 to August 9, 1990.

'Sampling locations are shown in Figure 3.1. Numbers for each sampling location represent identification numbers for the sample sites.

dThree samples collected and analyzed; results reported are median values, except for $\mathrm{pH}$ which is reported as a range of standard unit values.

${ }^{-}$Two samples collected and analyzed; results reported are median values, except for $\mathrm{pH}$ which is reported as a range of standard unit values.

'Results reported are from one sample at this location.

9Two samples collected and analyzed; results reported are median values, except for $\mathrm{pH}$ which is reported as a range of standard unit values.

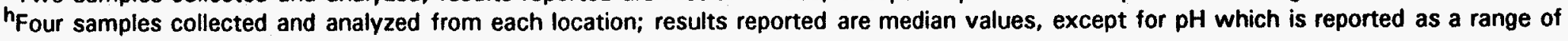
standard unit values.

'EPA secondary drinking water standards (40 CFR 143).

NA - Not applicable. 
values obtained from Rob Pit and Johnson Wash. Median sulfate and TDS concentrations from Lay Creek locations were higher than Johnson Wash sites, but less than the median reported from Rob Pit. All parameter values for the three Lay Creek sampling locations were similar and exhibited little variance.

\subsubsection{Ground water}

The uppermost aquifer at the Maybell site is the upper sandstone unit of the Browns Park Formation. Unconfined ground water occurs within this formation at depths ranging from 35 to greater than $300 \mathrm{ft}(11$ to greater than $91 \mathrm{~m})$ beneath the ground surface. The average hydraulic conductivity of this aquifer is 1.7 feet per day (ft/day) $\left(6 \times 10^{-4}\right.$ centimeters per second $\left.[\mathrm{cm} / \mathrm{sec}]\right)$, and the average linear ground water velocity is $0.17 \mathrm{ft} / \mathrm{day}(62 \mathrm{ft} / \mathrm{yr})\left(6.0 \times 10^{-5}\right.$ $\mathrm{cm} / \mathrm{sec}$ ).

Background ground water quality in the Browns Park Formation aquifer is highly variable because of naturally occurring mineralization. Concentrations of the EPA hazardous constituents in background ground water samples vary from below laboratory method reporting limits to several orders of magnitude above the proposed EPA ground water protection and cleanup standards. Naturally occurring reducing geochemical conditions exist within the Browns Park Formation aquifer in the vicinity of the Maybell tailings site. These conditions have prevented contamination of ground water resulting from the tailings pile and other site activities downgradient of the existing tailings piles.

The Maybell tailings site is located in a recharge area with a limited upslope catchment basin. Recharge to the Browns Park Formation uppermost aquifer is principally from the infiltration of precipitation in the form of rain or snow. Discharge of ground water from the uppermost aquifer is to the Yampa River alluvial aquifer system. Variations in the equipotential water table surface probably result from local differences in the amount of recharge available. The equipotential water table surface indicates that the ground water in the tailings pile vicinity is flowing away from the tailings site in a southwestward direction (Figure 3.2).

Ground water quality investigations have included sampling of background ground water from upgradient and downgradient monitor wells, and characterization of the tailings pile as a contaminant source. Table 3.2 presents the results of these investigations. Background ground water quality has been determined by chemical analyses of ground water samples collected from monitor wells 601,602,650,660,671,690,692,693, and 694 completed in the Browns Park Formation. These monitor wells are located upgradient or sufficiently far downgradient from the tailings pile in areas not affected by tailings leachate, but in areas that may have been affected by ambient uranium mineralization and mining activities. Monitor well 650 is a domestic well completed in the Browns Park Formation. It is located north of the Yampa River near the town of Maybell and is approximately $5 \mathrm{mi}(8 \mathrm{~km})$ west-southwest of the tailings pile. Its location is not shown on Figure 3.2. 


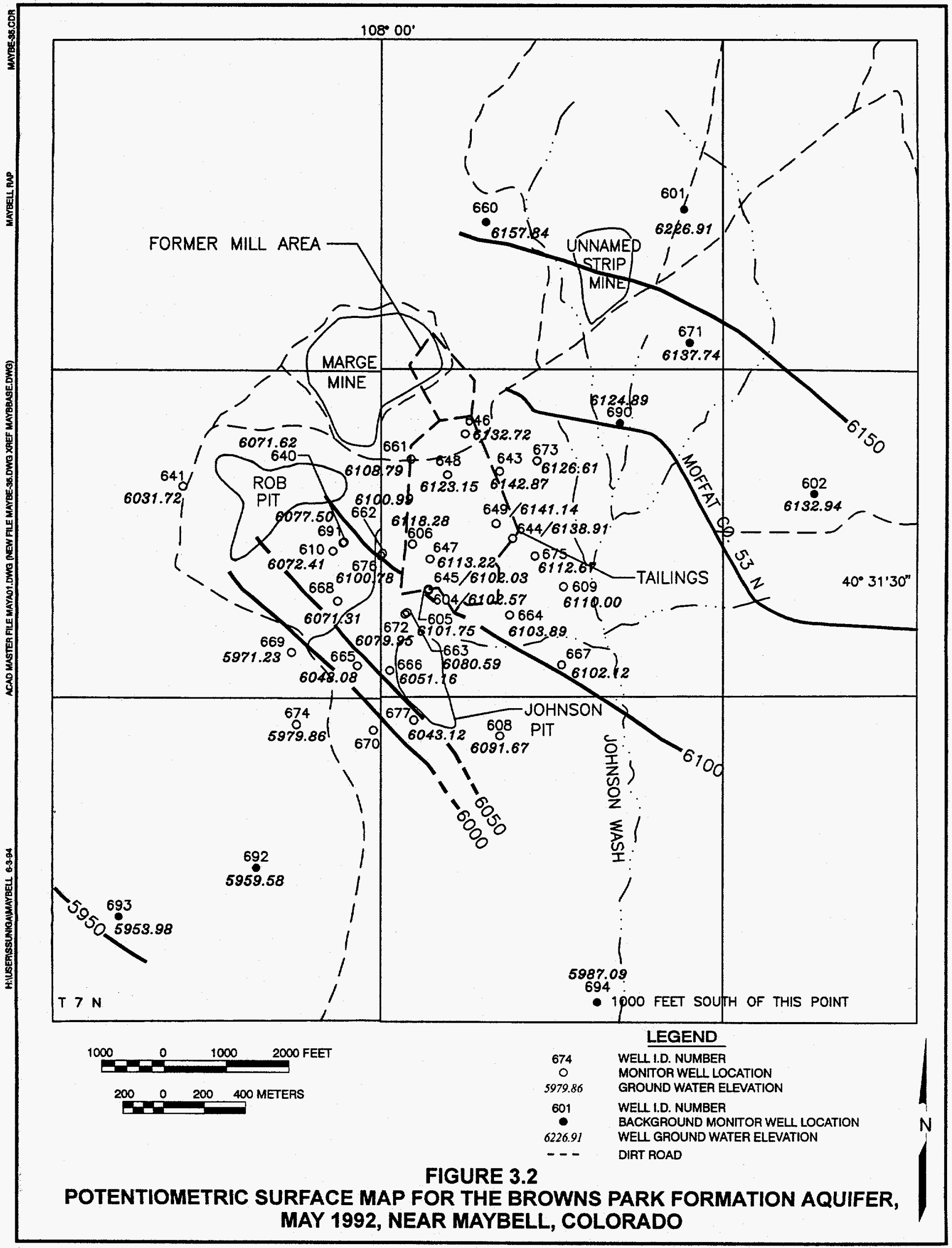


Table 3.2 Hazardous constituents detected in ground water and tailings pore water at the Maybell tailings site, Moffat County, Colorado

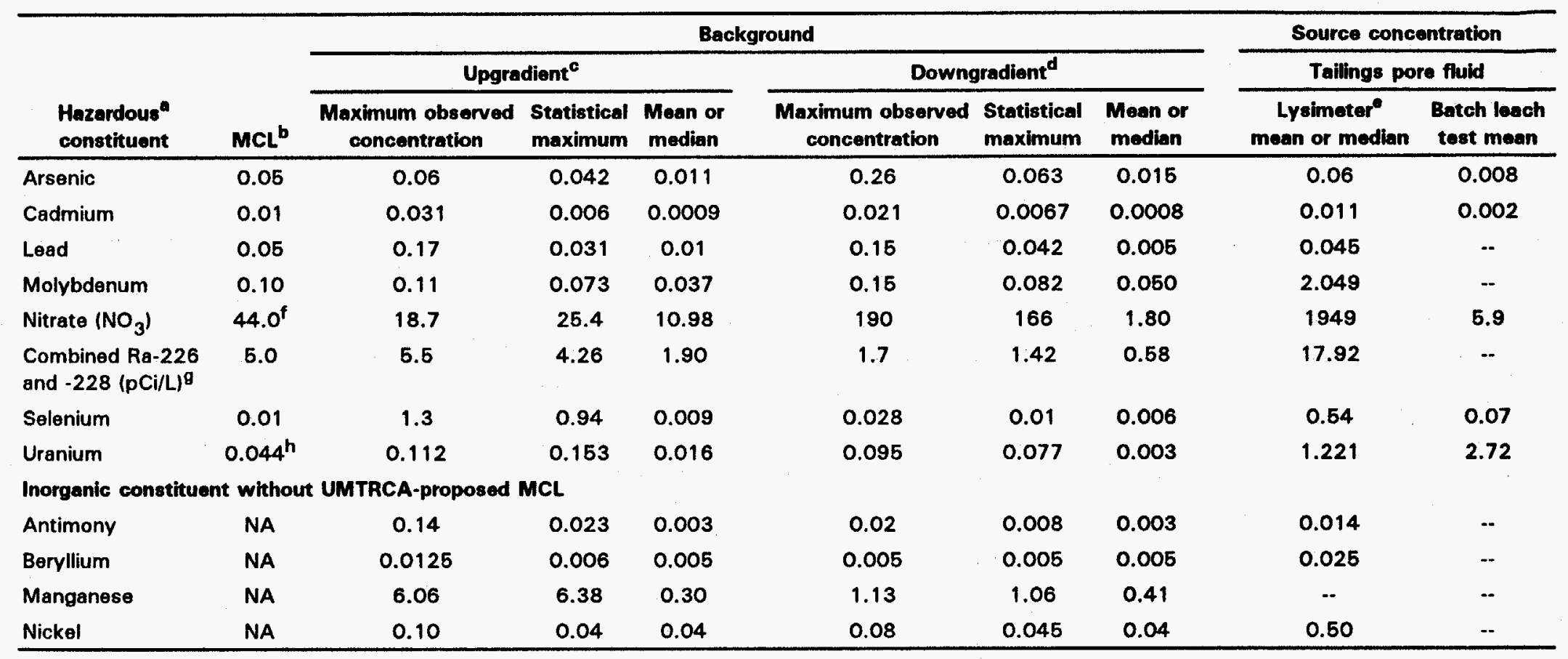

a Hazardous constituents from Table 1 of 40 CFR 264.94 and Table A of 40 CFR 192.02(a)(3)(ii) (proposed standards)

(62 FR 36000). All concentrations in $\mathrm{mg} / \mathrm{L}$ unless noted.

${ }^{\mathrm{MCL}-m a x i m u m}$ concentration limit. Table 1 of 40 CFR 264.94 and Table A of 40 CFR 192.02(a)(3)(ii) (proposed standards) (52 FR 36000 ).

Upgradient background ground water-from monitor wells 601,602,660,671, and 690 .

dDowngradient background ground water-from monitor wells 650, 692, 693, and 694 .

'Lysimeter mean or median-lysimeter data are weighted from lysimeters 081,083 , and 085 located on the tailings pile.

f The MCL for nitrate as (N) is $10 \mathrm{mg} / \mathrm{L}$.

$g_{\mathrm{pCi} / L-p i c o c u r i e s}$ per liter.

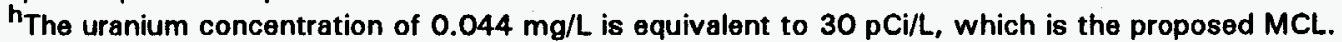


Portions of the ore deposit have become oxidized through mining activities, which has resulted in elevated concentrations with respect to the EPA maximum concentration limits (MCL) of arsenic, cadmium, molybdenum, nitrate, lead, selenium, uranium, and the combined activities of Ra-226 and radium-228 (Ra-228) in the background ground water. Table 3.2 presents a comparison between background ground water quality located upgradient and downgradient from the tailings pile.

Analysis of the background ground water data in Table 3.2 indicates variability between upgradient and downgradient background locations. Maximum observed concentrations of the hazardous constituents cadmium, lead, selenium, and uranium, and the combined activities of Ra-226 and Ra-228, are higher in upgradient background ground water locations. Downgradient background locations have greater maximum observed concentrations of arsenic, molybdenum, and nitrate.

Existing source concentrations of hazardous constituents in the Maybell tailings pile were estimated by chemical analyses of water samples from suction lysimeters installed in the tailings pile and from chemical analyses of water derived from batch leach tests on tailings materials. Hazardous constituents analyzed were those listed in Table 1 of 40 CFR 264.94 and Table A of the proposed EPA ground water protection and cleanup standards in $40 \mathrm{CFR}$ 192.02(a)(3)(ii) and 52 FR 36000 . Table 3.2 presents the results of characterization of the tailings materials. The constituents listed include the hazardous constituents that exceeded proposed EPA MCLs and other inorganic constituents that do not have MCLs. For all constituents listed in Table 3.2, the mean or median concentrations detected in the tailings pore fluid analyses were higher than the mean or median concentrations detected in background ground water samples from either upgradient or downgradient monitor wells.

Background ground water data presented in Table 3.2 also were compared to the state of Colorado agricultural standards (CDPHE, 1990). Results of this comparison are presented in Table 3.3. In downgradient background ground water wells, maximum observed concentrations for arsenic, boron, cadmium, chromium, lead, manganese, molybdenum, combined nitrate and nitrite, and selenium exceeded the agricultural standards in one or more monitor wells. In upgradient background ground water wells, maximum observed concentrations for cadmium, lead, manganese, molybdenum, and selenium exceeded the agricultural standards in one or more monitor wells. Upgradient background ground water monitor well 601 has an acidic $\mathrm{pH}(4.94)$ that falls below agricultural standard range $(6.5$ to 8.5$)$; this variation may be a result of localized sulfide mineral oxidation within the ore zones at the site. Elevated concentrations of manganese and selenium appear to be widespread since these constituents each exceed the agricultural standards in 6 of the 9 upgradient and downgradient background ground water monitor wells.

The nearest downgradient domestic well is $3 \mathrm{mi}(5 \mathrm{~km})$ south of the Maybell processing site and is completed in the Yampa River Valley alluvium, which is 
Table 3.3 Maximum observed concentrations for those constituents that have exceeded the state of Colorado's agricultural standards in background monitor wells

\begin{tabular}{|c|c|c|c|c|c|c|}
\hline \multicolumn{7}{|c|}{ Downgradient background monitor wells } \\
\hline Constituent & $\begin{array}{c}\text { Agricultural standard } \\
\text { (mg/L) }\end{array}$ & 650 & \multicolumn{2}{|c|}{692} & 693 & 694 \\
\hline Arsenic & 0.1 & 0.012 & \multicolumn{2}{|c|}{$0.26^{\mathrm{a}}$} & 0.02 & 0.022 \\
\hline Boron & 0.75 & 0.17 & \multicolumn{2}{|c|}{0.08} & 0.12 & 0.77 \\
\hline Cadmium & 0.01 & 0.021 & \multicolumn{2}{|c|}{$<0.001$} & 0.001 & 0.005 \\
\hline Chromium & 0.1 & 0.14 & \multicolumn{2}{|c|}{0.06} & 0.10 & 0.02 \\
\hline Lead & 0.1 & 0.15 & \multicolumn{2}{|c|}{$<0.01$} & 0.01 & 0.01 \\
\hline Manganese & 0.2 & 1.13 & \multicolumn{2}{|c|}{0.10} & 0.85 & 0.29 \\
\hline Molybdenum & 0.10 & 0.08 & \multicolumn{2}{|c|}{0.15} & 0.28 & 0.02 \\
\hline Nitrite and nirate & 100 & 190 & \multicolumn{2}{|c|}{4.9} & 7.1 & 9.7 \\
\hline Selenium & 0.02 & 0.023 & \multicolumn{2}{|c|}{$<0.03$} & 0.028 & 0.013 \\
\hline $\mathrm{pH}$ & $6.5-8.5$ & 7.10 & \multicolumn{2}{|c|}{6.67} & 6.57 & 7.05 \\
\hline \multicolumn{7}{|c|}{ Upgradient background monitor wells } \\
\hline Constituent & $\begin{array}{c}\text { Agricultural standard } \\
\text { (mg/L) }\end{array}$ & 601 & 602 & 660 & 671 & 690 \\
\hline Arsenic & 0.1 & 0.017 & 0.06 & 0.024 & 0.015 & 0.013 \\
\hline Boron & 0.75 & 0.07 & 0.07 & $<0.1$ & 1.1 & 0.14 \\
\hline Cadmium & 0.01 & 0.031 & 0.007 & $<0.005$ & $<0.001$ & $<0.001$ \\
\hline Chromium & 0.1 & 0.014 & 0.05 & $<0.01$ & $<0.01$ & $<0.01$ \\
\hline Lead & 0.1 & 0.17 & 0.05 & $<0.03$ & $<0.01$ & 0.01 \\
\hline Manganese & 0.2 & 6.06 & 0.11 & 0.68 & 0.06 & 0.61 \\
\hline Molybdenum & 0.10 & 0.06 & 0.10 & 0.02 & 0.02 & 0.08 \\
\hline Nitrite and nirate & 100 & 11.9 & 4.0 & 10 & 18.7 & 1.9 \\
\hline Selenium & 0.02 & 1.3 & 0.005 & 0.022 & 0.024 & 0.025 \\
\hline $\mathrm{pH}$ & $6.5-8.5$ & 4.94 & 6.75 & 6.17 & 7.08 & 6.86 \\
\hline
\end{tabular}

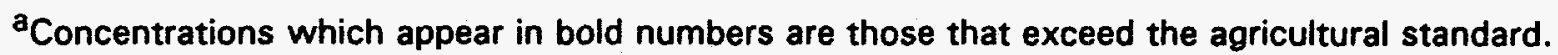
Reference: Colorado Department of Public Health and Environment (CDPHE), 1990. 
recharged by the Browns Park Formation. Water from this well has not been affected by contamination from the tailings pile. Ground water from the Browns Park Formation has been used for limited livestock watering as two windmilloperated wells formerly existed for this purpose. One windmill-operated well was located along Johnson Wash approximately $1 \mathrm{mi}(1.6 \mathrm{~km})$ south of the tailings pile. Field surveys conducted by the TAC observed this windmill in 1990 (TAC, 1990), but the entire above-ground structure was observed to have been removed during a 1992 field survey (TAC, 1992). The second windmilloperated well was located $2.3 \mathrm{mi}(3.7 \mathrm{~km})$ northeast of the tailings pile. Field sampling by a TAC subcontractor in 1987 found this windmill well to be unsecured and no monitor well cap was present. Discussions with the well owner indicated that the owner had not utilized this windmill for five years, since about 1982 (Mclntyre, 1987).

\subsection{FLORA AND FAUNA}

This section summarizes flora and fauna at the Maybell processing site and the proposed borrow sites. More details regarding flora and fauna and threatened and endangered species appear in Attachment 1. Biological Assessment, of this EA.

\subsubsection{Maybell tailings site}

The Maybell tailings site is in a sagebrush-steppe habitat within the Wyoming Basin (Kuchler, 1975). Sagebrush-dominated habitat is the most common plant community within the site area. Open juniper-dominated woods are also common and occur on the low ridges near the site. The plant communities at the site include disturbed areas planted with crested wheatgrass (tailings pile) and yellow sweet clover (Rob Pit overburden pile). Other early successional plant species occur in these areas. Sagebrush habitat occurs adjacent to the tailings pile in windblown-contaminated areas and along sections of Johnson Wash. Riparian vegetation occurs along other sections of Johnson Wash as well as along contaminated sections of Lay Creek. The riparian zone is characterized by a fairly dense growth of early successional species and areas dominated by wetland species. Aquatic and wetlands habitat occur along Lay Creek, which may be ephemeral during dry years or perennial during wet years. Baltic rush is the most common wetland species growing along Lay Creek. A more detailed description of wetlands along Johnson Wash and Lay Creek appears in Attachment 2, Floodplain/Wetlands Assessment.

Three species of reptiles (western rattlesnake, racer, and sagebrush lizard) and one species of amphibian (leopard frog) were observed during site reconnaissance surveys. An additional 11 species of reptiles and amphibians could occur on the site. Of the 69 species of birds observed at or near the site, the western meadowlark was most common on the grassy disturbed sites, while common species in the sagebrush habitat include the sage sparrow and mourning dove. Birds of prey observed were the kestrel, red-tailed hawk, and golden eagle. Game species observed were the sage grouse in the sagebrush 
habitat and nesting waterfowl (green-winged teal and northern shoveller) along Lay Creek.

The sage grouse occurs in the site area, and critical habitat features for this species are leks (display grounds used by grouse during the reproductive period), nesting habitat, brood habitat, and wintering habitat. The Mud Spring lek is the nearest lek to the site and is $4 \mathrm{mi}(6 \mathrm{~km})$ to the north (Petch, 1992). Sage grouse typically nest within $2 \mathrm{mi}(3 \mathrm{~km})$ of the lek (Berry and Eng, 1985; Hoffman, 1979); it is unlikely that grouse from the Mud Spring lek would nest in the site area given its distance from the lek and the existence of a pinon-juniper ridge between the lek and the site. Sage grouse broods rely on invertebrates and forbs for food (Dunn and Braun, 1986; Hoffman, 1979; Klebenow, 1969) and as forbs dry up in the upland areas in the summer, broods move to riparian areas to feed. The sagebrush habitat around the site would be expected to provide brood habitat early in the brood rearing season, while habitat along Lay Creek would likely provide brood habitat later in the season. Johnson Wash would provide only marginal brood habitat because it is flanked by steep-sided juniper-covered slopes and provides little escape cover (Navo, 1986). There are no documented sage grouse wintering areas near the site.

No small mammal surveys were conducted; information from the literature indicates that approximately 18 species of small mammals may occur on the site. The coyote was the only large carnivore observed, although the bobcat is also likely to occur. Big game species observed were the mule deer, elk, and pronghorn antelope. Elk winter in small numbers (40 to 50 animals) in the juniper plant community near the site (Grahm, 1986) and their signs are common on the tailings pile (TAC, 1992).

The mule deer is a year-round resident in the area of the Maybell site. The site area is also part of a large winter concentration area and is designated severe winter range during harsh winters. Wintering deer include the resident population plus animals that move to the area from as far away as $40 \mathrm{mi}$ $(65 \mathrm{~km})$. The number of wintering deer at the site area increases with increasing snow depth; their numbers can be three times the summer deer density. For example, the summer population in 1985 was 10 deer per square mile (4 per square kilometer) and the winter population was 32 deer per square mile (12 per square kilometer). The wintering period is generally from the first of December through April (CDOW, 1986a, 1985a, 1983a).

The habitat in the site area provides year-round and winter range for the pronghorn antelope. The pronghorn population density in the site area for the period 1975 through 1985 ranged from four to eight per square mile (1.5 to 3 per square kilometer). During a severe winter, the pronghorn mortality rate can be high; the estimated mortality rate was 53 percent during the severe winter of 1983 to 1984 (CDOW, 1986b, 1985b, 1983b). 


\subsubsection{Borrow sites}

The Rob Pit overburden pile is on BLM-administered land and is within the designated site boundary and shares the same habitat, sagebrush-steppe, as the Maybell site. The Juniper Mountain Limestone Quarry is in open juniper woods; pinon pine is rare in this area. The shrub layer is dominated by big sagebrush, and species such as broom snakeweed and rabbitbrush are also common. The Maybell gravel source is on a terrace above the Yampa River and has previously been used as a borrow site. Vegetation is sparse, with rabbitbrush being the most predominant shrub and with low-growing annuals as the ground cover.

The Craig Basalt Quarry is an existing quarry and is not considered further regarding flora and fauna. Elk use of the Juniper Mountain Limestone Quarry is common, as evidenced by the abundant sign observed. Wildlife use of the Maybell gravel source is light, given the sparse vegetative growth in this area. There is a large cattail and Carex (sedge)-dominated wetland along the western border of the gravel source, and an irrigation ditch bordered by wetland vegetation occurs along the southern border. The Yampa River is along the northern edge of the gravel source and is bordered by riparian-wetland vegetation.

\subsubsection{Threatened and endangered species}

According to the FWS, seven federally listed threatened and endangered species have the potential to occur near the Maybell site. These seven species include the bald eagle (Haliaeetus leucocephalus), the black-footed ferret (Mustela nigripes), the humpback chub (Gila cypha), the bonytail chub (Gila elegans), the razorback sucker (Xyrauchen texanus), the Colorado squawfish (Ptychocheilus lucius), and the Ute ladies'-tresses (Spiranthes diluvialis) (Rose, 1992). The status of federally listed threatened and endangered species at the Maybell site is analyzed in Attachment 1, Biological Assessment and summarized below.

The bald eagle winters and nests along the Yampa River. The closest nesting bald eagles are two pairs of birds approximately $20 \mathrm{mi}(32 \mathrm{~km})$ east of the tailings site near Craig, Colorado. Twenty-five to 50 bald eagles may winter along the Yampa River between Craig and Sunbeam, Colorado (Petch, 1992).

The black-footed ferret was judged not to occur at or near the site due to the lack of prairie dog towns, its principle area of residence. The humpback chub, bonytail chub, and razorback sucker were also judged not to occur at or near the site due to the lack of suitable aquatic habitat.

The Colorado squawfish does occur in the Yampa River near the Maybell gravel source. Potential habitat for the Ute ladies'-tresses occurs along Johnson Wash and Lay Creek and possibly at the Maybell gravel source.

Five federal candidate species are also possible inhabitants near the Maybell site. These five species includes the loggerhead shrike (Lanius ludovicianus), 
the northern goshawk (Accipiter gentilis), the Columbian sharp-tailed grouse (Tympanuchus phasianellus columbianus), the flannelmouth sucker (Catostomus latipinnis), and the Wetherill milkvetch (Astragalus wetherillin (Rose, 1992).

The loggerhead shrike occurs as a breeding species throughout most of Colorado, including the Maybell site area (Kingery and Graul, 1978). However, this species has declined in numbers steadily over most of its range, including Colorado. The reasons for this decline are not yet understood. Wildlife surveys over the past 10 years have not recorded this species in the Maybell area (DOE, 1983; TAC, 1986a, 1987, 1989, 1990, 1992; Toolen, 1992). Therefore it is unlikely that this species has or would occur at or near the Maybell site or associated borrow sites.

The northern goshawk is a year-round resident in northwest Colorado (Kingery and Graul, 1978). This species prefers mature conifer forests, habitat which is not present at the tailings site. Mature conifer forest habitat is present at only two of the borrow sites, the Juniper Mountain Limestone Quarry and the Craig Basalt Quarry. Both borrow sites are existing operations.

The Columbian sharp-tailed grouse has been reduced to remnant populations throughout most of its range. This species prefers a selected mountain shrub habitat which is not present at the Maybell site or the proposed borrow sites. Based on the lack of appropriate habitat, it is likely that this species does not occur in any of the areas affected by the proposed remedial action.

The flannelmouth sucker is an indigenous fish species in the Yampa River (Wick et al., 1985). The only activity associated with the remedial action at the Maybell site that would take place near the Yampa River would be at the Maybell gravel source.

The Wetherill milkvetch is a perennial plant that is found in six counties in Colorado, including Moffat County. A field survey for this species was conducted in the tailings pile area during August 1993. No populations of this species were found during the survey. The closest known Wetherill milkvetch population to the Maybell site is in open pinon-juniper woods in the Juniper Canyon area above the Yampa River. This population is approximately $5 \mathrm{mi}$ $(8 \mathrm{~km})$ south of the tailings pile (Bunin, 1992). The only other population in Moffat County is near Craig, Colorado.

\subsection{RADIATION}

\subsubsection{Background radiation}

Specific background radiation measurements taken near the Maybell tailings site are presented in Table 3.4. Background gamma exposure rates ranged from 7.0 to 15.0 microroentgens per hour $(\mu \mathrm{R} / \mathrm{hr})$ and averaged $14.0 \mu \mathrm{R} / \mathrm{hr}$. Background outdoor radon concentrations measured from April 27,1989 , to June 6, 1990, averaged 0.7 picocuries per liter $(\mathrm{pCi} / \mathrm{L})\left(2.59 \mathrm{mBq} / \mathrm{m}^{3}\right)$ and ranged from 0.3 to 
Table 3.4 Background and on-site radiation measurements for the Maybell, Colorado, processing site near Maybell, Colorado

\begin{tabular}{|c|c|c|c|}
\hline Measurement & Average & Range & Source \\
\hline \multicolumn{4}{|l|}{$\begin{array}{l}\text { Gamma exposure rate } \\
(\mu \mathrm{R} / \mathrm{hr})\end{array}$} \\
\hline Background & 14 & $7-15$ & EG\&G, 1982 \\
\hline Tailings pile & 120 & $30-300$ & BFEC, 1985 \\
\hline Mill yard/ore storage & 73 & $29-248$ & BFEC, 1985 \\
\hline Windblown & 30 & $17-70$ & BFEC, 1985 \\
\hline \multicolumn{4}{|l|}{$\begin{array}{l}\text { Radon in air } \\
\mathrm{pCi} / \mathrm{L}\left(\mathrm{mBq} / \mathrm{m}^{3}\right)\end{array}$} \\
\hline Background & $\begin{array}{c}0.7 \\
\left(2.59 \times 10^{4}\right)\end{array}$ & $\begin{array}{c}0.3-2.8 \\
\left(1.11 \times 10^{4}-1.04 \times 10^{5}\right)\end{array}$ & DOE, 1990 \\
\hline Tailings site & $\begin{array}{c}3.4 \\
\left(1.26 \times 10^{5}\right)\end{array}$ & $\begin{array}{c}1.1-5.0 \\
\left(4.07 \times 10^{4}-1.85 \times 10^{5}\right)\end{array}$ & $\mathrm{DOE}, 1990$ \\
\hline \multicolumn{4}{|l|}{$\begin{array}{l}\text { Radon surface flux } \\
\mathrm{pCi} / \mathrm{m}^{2} \sec \left(\mathrm{mBq} / \mathrm{m}^{2} \mathrm{sec}\right)\end{array}$} \\
\hline Background & $\begin{array}{l}10^{\mathrm{a}} \\
(370)^{\mathrm{a}}\end{array}$ & $\begin{array}{c}10^{a} \\
(370)^{a}\end{array}$ & FBDU, 1981 \\
\hline $\begin{array}{c}\text { Tailings site } \\
(1976) \\
(1980)\end{array}$ & $\begin{array}{c}87 \\
(3219) \\
125 \\
(4625)\end{array}$ & $\begin{array}{c}75-99 \\
(2775-3663) \\
73-191 \\
(2701-7067)\end{array}$ & $\begin{array}{l}\text { FBDU, } 1981 \\
\text { FBDU, } 1981\end{array}$ \\
\hline \multicolumn{4}{|l|}{$\begin{array}{l}\text { Soil concentrations } \\
\mathrm{pCi} / \mathrm{g}(\mathrm{mBq} / \mathrm{g})\end{array}$} \\
\hline $\begin{array}{l}\text { Background } \\
\text { Uranium }\end{array}$ & $\begin{array}{c}3.1 \\
(114.7)\end{array}$ & $\begin{array}{c}1.4-5.6 \\
(51.8-207.2)\end{array}$ & BFEC, 1985 \\
\hline Th-230 & $\begin{array}{c}1.3 \\
(48.1)\end{array}$ & $\begin{array}{c}1.0-1.7 \\
(37.0-62.9)\end{array}$ & BFEC, 1985 \\
\hline $\mathrm{Ra}-226$ & $\begin{array}{c}1.4 \\
(51.8)\end{array}$ & $\begin{array}{c}0.5-2.2 \\
(18.5-81.4)\end{array}$ & BFEC, 1985 \\
\hline
\end{tabular}


Table 3.4 Background and on-site radiation measurements for the Maybell, Colorado, processing site near Maybell, Colorado (Concluded)

\begin{tabular}{|c|c|c|c|}
\hline Measurement & Average & Range & Source \\
\hline \multicolumn{4}{|l|}{ Tailings site } \\
\hline $\begin{array}{l}\text { Uranium } \\
\text { Th-230 } \\
\text { Ra-226 }\end{array}$ & $\begin{array}{c}34 \\
(1258) \\
230 \\
(8510) \\
201 \\
(7437)\end{array}$ & $\begin{array}{c}1-505 \\
\left(37.0-1.87 \times 10^{4}\right) \\
3-575 \\
\left(111.0-2.13 \times 10^{4}\right) \\
3-1107 \\
\left(111.0-4.10 \times 10^{4}\right)\end{array}$ & $\begin{array}{l}\text { MSRD, } 1982 \\
\text { BFEC, } 1985 \\
\text { BFEC, } 1985\end{array}$ \\
\hline $\begin{array}{r}\text { Mill yard/ore storage } \\
\text { Th-230 } \\
\text { Ra-226 }\end{array}$ & $\begin{array}{c}103 \\
(3811) \\
44 \\
(1628)\end{array}$ & $\begin{array}{c}7-329 \\
\left(259.0-1.22 \times 10^{4}\right) \\
1-924 \\
\left(37.0-3.42 \times 10^{4}\right)\end{array}$ & $\begin{array}{l}\text { BFEC, } 1985 \\
\text { BFEC, } 1985\end{array}$ \\
\hline \multicolumn{4}{|l|}{$\begin{array}{l}\text { Ground water } \\
\mathrm{pCi} / \mathrm{L}\left(\mathrm{mBq} / \mathrm{m}^{3}\right)\end{array}$} \\
\hline $\begin{array}{l}\text { Background } \\
\qquad \begin{array}{l}\text { Gross } \\
\text { alpha } \\
\text { Uranium } \\
\text { Ra-226 }\end{array}\end{array}$ & $\begin{array}{c}10 \\
\left(3.7 \times 10^{5}\right) \\
7.3 \\
\left(2.70 \times 10^{5}\right) \\
0.6 \\
\left(2.20 \times 10^{4}\right)\end{array}$ & $\begin{array}{c}0.0-45 \\
\left(0.0-1.67 \times 10^{6}\right) \\
0.2-37 \\
\left(7.40 \times 10^{3}-1.37 \times 10^{6}\right) \\
0.1-0.8 \\
\left(3.70 \times 10^{3}-2.96 \times 10^{4}\right)\end{array}$ & $\begin{array}{l}\text { TAC, } 1986 \mathrm{~b} \\
\text { TAC, } 1986 \mathrm{~b} \\
\text { TAC, } 1986 \mathrm{~b}\end{array}$ \\
\hline $\begin{array}{l}\text { Tailings site } \\
\qquad \begin{array}{l}\text { Gross } \\
\text { alpha } \\
\text { Uranium } \\
\text { Ra-226 }\end{array}\end{array}$ & $\begin{array}{c}1300 \\
\left(4.81 \times 10^{7}\right) \\
1100 \\
\left(4.07 \times 10^{7}\right) \\
1.2 \\
\left(4.44 \times 10^{4}\right)\end{array}$ & $\begin{array}{c}22-3500 \\
\left(8.14 \times 10^{5}-1.30 \times 10^{8}\right) \\
14-3750 \\
\left(5.18 \times 10^{5}-1.39 \times 10^{8}\right) \\
0.1-2.1 \\
\left(3.70 \times 10^{3}-7.77 \times 10^{4}\right)\end{array}$ & $\begin{array}{l}\text { TAC, 1986b } \\
\text { TAC, 1986b } \\
\text { TAC, 1986b }\end{array}$ \\
\hline
\end{tabular}

${ }^{a}$ Value reported based on one measurement. 
$2.8 \mathrm{pCi} / \mathrm{L}\left(1.11 \times 10^{4}\right.$ to $\left.1.04 \times 10^{5} \mathrm{mBq} / \mathrm{m}^{3}\right)$. A background radon flux measurement taken $1 \mathrm{mi}(1.6 \mathrm{~km})$ northeast of the tailings pile gave a value of $10 \mathrm{pCi} / \mathrm{m}^{2} \mathrm{sec}\left(370 \mathrm{mBq} / \mathrm{m}^{2} \mathrm{sec}\right)$.

Background soil samples collected at four locations near the Maybell tailings site were analyzed for uranium-238 (U-238), thorium-230 (Th-230), and Ra-226 concentrations. Uranium-238 concentrations averaged $3.1 \mathrm{pCi} / \mathrm{g}(114.7 \mathrm{mBq} / \mathrm{g})$ and ranged from 1.4 to $5.6 \mathrm{pCi} / \mathrm{g}(51.8$ to $207.2 \mathrm{mBq} / \mathrm{g})$. Thorium-230 concentrations averaged $1.3 \mathrm{pCi} / \mathrm{g}(48.1 \mathrm{mBq} / \mathrm{g})$ and ranged from 1.0 to $1.7 \mathrm{pCi} / \mathrm{g}(37.0$ to $62.9 \mathrm{mBq} / \mathrm{g})$. Radium-226 concentrations averaged $1.4 \mathrm{pCi} / \mathrm{g}(51.8 \mathrm{mBq} / \mathrm{g})$ and ranged from 0.5 to $2.2 \mathrm{pCi} / \mathrm{g}(18.5$ to $81.4 \mathrm{mBq} / \mathrm{g})$.

Radioactivity concentrations in background ground water samples were measured for gross alpha, U-238, and Ra-226. Gross alpha concentrations averaged $10 \mathrm{pCi} / \mathrm{L}\left(3.7 \times 10^{5} \mathrm{mBq} / \mathrm{m}^{3}\right)$ and ranged from 0 to $45 \mathrm{pCi} / \mathrm{L} 10$ to $\left.1.67 \times 10^{6} \mathrm{mBq} / \mathrm{m}^{3}\right)$. Uranium-238 concentrations averaged $7.3 \mathrm{pCi} / \mathrm{L}(2.70 \times$ $\left.10^{5} \mathrm{mBq} / \mathrm{m}^{3}\right)$ and ranged from 0.2 to $37 \mathrm{pCi} / \mathrm{L}\left(7.40 \times 10^{3}\right.$ to $1.37 \times 10^{6}$ $\left.\mathrm{mBq} / \mathrm{m}^{3}\right)$. Radium-226 concentrations averaged $0.6 \mathrm{pCi} / \mathrm{L}\left(2.20 \times 10^{4} \mathrm{mBq} / \mathrm{m}^{3}\right)$ and ranged from 0.1 to $0.8 \mathrm{pCi} / \mathrm{L}\left(3.70 \times 10^{3}\right.$ to $\left.2.96 \times 10^{4} \mathrm{mBq} / \mathrm{m}^{3}\right)$.

\subsubsection{Radiation levels}

A field survey of the proposed tailings site (existing tailings pile location) and the surrounding areas was conducted to establish the extent and degree of contamination (BFEC, 1985) (see Figure 1.3). Specific measurements are presented in Table 3.4 .

Gamma exposure rates at the existing tailings pile averaged $120 \mu \mathrm{R} / \mathrm{hr}$ and ranged from 30 to $300 \mu R / h r$. Gamma exposure rates at the mill yard/ore storage area (off-pile area) averaged $73 \mu \mathrm{R} / \mathrm{hr}$ and ranged from 29 to $248 \mu \mathrm{R} / \mathrm{hr}$. Average gamma exposure rates at the windblown area (off-pile area) averaged $30 \mu \mathrm{R} / \mathrm{hr}$ and ranged from 17 to $70 \mu \mathrm{R} / \mathrm{hr}$. Gamma exposure rates elevated above background extended $1000 \mathrm{ft}(300 \mathrm{~m})$ in the predominant downwind direction (east-northeast). Gamma exposure rates in Johnson Wash and Lay Creek ranged from 17 to 33 and 16 to $39 \mu \mathrm{R} / \mathrm{hr}$, respectively (BFEC, 1985).

Gross alpha concentrations of $362 \mathrm{pCi} / \mathrm{L}\left(1.34 \times 10^{7} \mathrm{mBq} / \mathrm{m}^{3}\right)$ were observed in surface water from Rob Pit. Filtered surface water samples collected from standing water in Johnson Wash at the foot of the tailings pile had Ra-226, lead-210 (Pb-210), and Th-230 concentrations of $12.8,73$, and $200 \mathrm{pCi} / \mathrm{L}$ $\left(4.74 \times 10^{5}, 2.70 \times 10^{6}\right.$, and $\left.7.40 \times 10^{6} \mathrm{mBq} / \mathrm{m}^{3}\right)$, respectively (FBDU, 1981 ; ORNL, 1980). Samples of standing surface water from Lay Creek and Johnson Wash had Ra-226 and Th-230 concentrations ranging from 0.2 to $2.6 \mathrm{pCi} / \mathrm{L}$ (7400 to $9.62 \times 10^{4} \mathrm{mBq} / \mathrm{m}^{3}$ ) (FBDU, 1981; ORNL, 1980).

Mean gross alpha, $\mathrm{Pb}-210$, and $\mathrm{U}-238$ concentrations in filtered ground water samples from wells completed on or immediately adjacent to the tailings pile were elevated above background levels. No significant increases over 
background levels were observed for Th-230, Ra-226, or polonium-210 (TAC, 1986b).

The average uranium, Th-230, and Ra-226 concentrations in the tailings pile were 34, 230, and $201 \mathrm{pCi} / \mathrm{g}(1258,8510$, and $7437 \mathrm{mBq} / \mathrm{g})$, respectively (MSRD, 1982; BFEC, 1985). Concentrations of uranium ranged from 1 to 505 $\mathrm{pCi} / \mathrm{g}$ (37 to $1.87 \times 10^{4} \mathrm{mBq} / \mathrm{g}$ ). Concentrations of Th-230 ranged from 3 to $575 \mathrm{pCi} / \mathrm{g}\left(111\right.$ to $\left.2.13 \times 10^{4} \mathrm{mBq} / \mathrm{g}\right)$. Radium-226 concentrations ranged from 3 to $1107 \mathrm{pCi} / \mathrm{g}\left(111\right.$ to $\left.4.10 \times 10^{4} \mathrm{mBq} / \mathrm{g}\right)$. Soils beneath the tailings pile were also contaminated and exceeded the EPA standards for Ra-226 (40 CFR $192.12(\mathrm{a}))$ to an average depth of $3.6 \mathrm{ft}(1.1 \mathrm{~m})$.

The mill yard/ore storage area had volume-weighted average Th-230 and Ra-226 concentrations of 103 and $44 \mathrm{pCi} / \mathrm{g}$ (3811 and $1628 \mathrm{mBq} / \mathrm{g})$, respectively (BFEC, 1985). Concentrations of Th-230 ranged from 7 to $329 \mathrm{pCi} / \mathrm{g}(259$ to $1.22 \times 10^{4} \mathrm{mBq} / \mathrm{g}$ ), and Ra-226 concentrations ranged from 1 to $924 \mathrm{pCi} / \mathrm{g}$ (37 to $3.42 \times 10^{4} \mathrm{mBq} / \mathrm{g}$ ). Soils in the mill yard exceeded the EPA standards for Ra-226 (40 CFR 192.12(a)) at a mean depth of $3.2 \mathrm{ft}(1.0 \mathrm{~m})$ in the mill yard and at a mean depth of $1.5 \mathrm{ft}(0.5 \mathrm{~m})$ in the surrounding ore storage area.

Ratios of Th-230 to U-238 in sediments collected from Johnson Wash and Lay Creek indicated that contamination from the Maybell tailings pile was present. Both Johnson Wash and Lay Creek sediments (Tables 3.5 and 3.6, respectively) contained Ra-226 and Th-230 concentrations exceeding established background soil concentrations presented in Table 3.4. Johnson Wash had Ra-226 and Th-230 concentrations that increased with depth up to 24 in $(61 \mathrm{~cm})$ (Table 3.5). Sediments in Lay Creek were also contaminated with Ra-226 and Th-230 in concentrations above background soil levels, but concentrations did not increase with depth (Table 3.6).

To examine radionuclide concentrations at depths below 24 in $(61 \mathrm{~cm})$, seven test pits were excavated in upper Johnson Wash and at the confluence with Lay Creek (TAC, 1986b). Results indicated that Ra-226 concentrations were less than $5 \mathrm{pCi} / \mathrm{g}(185 \mathrm{mBq} / \mathrm{g})$ at depths below $2 \mathrm{ft}(0.61 \mathrm{~m})$. However, Th-230 concentrations in excess of $35 \mathrm{pCi} / \mathrm{g}(1295 \mathrm{mBq} / \mathrm{g})$ extended to $4 \mathrm{ft}(1.2 \mathrm{~m})$ in one test pit near the tailings pile.

\section{6}

\section{LAND USE}

The Maybell processing site is $5 \mathrm{mi}(8 \mathrm{~km})$ northeast of the town of Maybell. The majority of the land around the site is under federal ownership and is administered by the BLM; however, there is private land south, east, and west of the site. The northern portion of the designated tailings site is on land administered by the BLM; the southern portion of the site is on private land. Umetco does not own any land at the site, but maintains control based upon its radioactive materials license held for the tailings site. 
Table 3.5 Average radionuclide concentrations in sediments from Johnson Wash as a function of depth

\begin{tabular}{|c|c|c|c|c|}
\hline \multirow{2}{*}{$\begin{array}{c}\text { Sediment } \\
\text { depth }\end{array}$} & \multicolumn{4}{|c|}{ Average concentration \pm standard error in $\mathrm{pCi} / \mathrm{g} \mathrm{dry}(\mathrm{mBq} / \mathrm{g} \mathrm{dry})^{\mathrm{a}}$} \\
\hline & \multicolumn{3}{|c|}{ Johnson Wash } & \multirow[b]{2}{*}{$\begin{array}{l}\text { No. of } \\
\text { samples }\end{array}$} \\
\hline in $(\mathrm{cm})$ & Ra-226 & $\begin{array}{c}\text { No. of } \\
\text { samples }\end{array}$ & Th-230 & \\
\hline $0-6$ & $5.7 \pm 1.1$ & 16 & $27.9 \pm 9.4$ & 16 \\
\hline$(0-15.2)$ & $(210.9 \pm 40.7)$ & & $(1032.3 \pm 347.8)$ & \\
\hline $6-12$ & $10.2 \pm 2.8$ & 16 & $38.1 \pm 13.2$ & 15 \\
\hline$(15.2-30.5)$ & $(377.4 \pm 103.6)$ & & $(1409.7 \pm 488.4)$ & \\
\hline $12-18$ & $12.1 \pm 4.9$ & 16 & $65.9 \pm 17.8$ & 13 \\
\hline$(30.5-45.7)$ & $(447.7 \pm 181.3)$ & & $(2438.3 \pm 658.6)$ & \\
\hline $18-24$ & $40.4 \pm 16.6$ & 11 & $N^{C}$ & \\
\hline$(45.7-61.0)$ & $(1494.8 \pm 614.2)$ & & & \\
\hline
\end{tabular}

${ }^{a}$ Concentrations in $\mathrm{pCi} / \mathrm{g}$; converted to $\mathrm{mBq} / \mathrm{g}$.

${ }^{b}$ Depth in inches; converted to centimeters in parentheses.

'Samples not collected for analysis. 
Table 3.6 Average radionuclide concentrations in sediments from Lay Creek as a function of depth

\begin{tabular}{ccccc}
\hline \multirow{2}{*}{$\begin{array}{c}\text { Sediment } \\
\text { depth }\end{array}$} & \multicolumn{5}{c}{ Average concentration \pm standard error in pCi/g dry (mBq/g dry) ${ }^{\mathrm{a}}$} \\
\cline { 2 - 5 } in (cm) & Ra-226 & No. of samples & Th-230 & No. of samples \\
\hline $0-6$ & $19.2 \pm 10.8$ & 54 & $24.1 \pm 10.5$ & 54 \\
$(0-15.2)$ & $(710.4 \pm 399.6)$ & & $(891.7 \pm 388.5)$ & 54 \\
$6-12$ & $15.4 \pm 5.4$ & 51 & $23.5 \pm 6.3$ & \\
$(15.2-30.5)$ & $(569.8 \pm 199.8)$ & & $(869.5 \pm 233.1)$ & \\
$12-18$ & $11.5 \pm 2.8$ & 52 & $19.4 \pm 4.9$ & \\
$(30.5-45.7)$ & $(425.5 \pm 103.6)$ & & $(717.8 \pm 181.3)$ & \\
$18-24$ & $10.1 \pm 1.5$ & 32 & $N^{c}$ & \\
$(45.7-61.0)$ & $(373.7 \pm 55.5)$ & & &
\end{tabular}

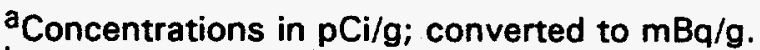

bepth in inches; converted to centimeters in parentheses.

'Samples not collected for analysis. 
Virtually all of the land around the site is used for low-density livestock grazing. The tailings site is within three BLM grazing leases that total 9369 ac (3792 ha) and have a combined grazing capacity of 954 animal unit-months (Hillberry, 1986).

Areas northeast, north-northwest, and south of the site have been disturbed by open pit mining and related activities. Within $1 \mathrm{mi}(1.6 \mathrm{~km})$ of the site there are four inactive open pit mines. There are 13 unpatented mill site claims in the vicinity of the proposed project area. At present, there are no ongoing mineral development activities at or around the site. The BLM offered one competitive oil and gas lease for sale on August 12, 1993. This lease, COC 55272 . includes the east one-half, northeast one-fourth, southeast one-fourth, and southwest one-fourth of Section 19, Township 7 North, Range 94 west. No other oil and gas leases are within the project-affected area (Husband, 1993).

\section{Borrow sites}

The Rob Pit overburden pile is on BLM land adjacent to the tailings pile. The three BLM grazing and one recently offered oil and gas lease described above for the tailings site also apply to this borrow site.

The Maybell gravel source borrow site is on private land along the Yampa River and is approximately $4.5 \mathrm{mi}(7.2 \mathrm{~km})$ west of the site. This privately-owned operation has provided gravel for local use.

The Juniper Mountain Limestone Quarry proposed borrow site is located on BLM land on Juniper Mountain. This existing mining operation is approximately $2.5 \mathrm{mi}(4 \mathrm{~km})$ south of U.S. Highway 40 and is about $7.2 \mathrm{road} \mathrm{mi}(11.6 \mathrm{~km})$ from the tailings site. The site is within a BLM grazing lease that contains 1422 ac (575 ha), with a grazing capacity of 161 animal unit-months. There are no oil and gas leases at this proposed borrow site location. There are 14 unpatented mining claims involved with the Juniper Mountain Limestone Quarry (Husband, 1993).

The Craig Basalt Quarry is located approximately 9 road mi $(14.5 \mathrm{~km})$ southeast of Craig, Colorado, and approximately 30 road $\mathrm{mi}(48 \mathrm{~km})$ from the site. This existing rock quarry is located on private property, but the minerals are owned by the federal government. The surrounding area is used primarily for livestock grazing.

The BLM-administered land in the vicinity of the Maybell site is designated open to recreational use by OHVs. The only public access for OHV recreationists is on Moffat County Road $53 \mathrm{~N}$. Significant OHV use is occurring on the surrounding overburden piles and pits adjacent to the Maybell tailings pile. The former Maybell mill site and other locations are used as a parking/staging area by OHV recreationists (Husband, 1993). 
The Yampa River is located south of the Maybell tailings pile (Figure 1.1). Recreation enthusiasts use the Yampa River for flatwater boating (Husband, 1993). Although the Yampa River is outside of the proposed project area, the Maybell gravel source is proposed for use as a borrow site and is located along the Yampa River approximately $4.5 \mathrm{mi}(7.2 \mathrm{~km})$ west of the tailings pile.

\subsection{CULTURAL RESOURCES}

A Class III cultural resource survey of 1120 ac (453 ha) surrounding the Maybell site which included the Rob Pit overburden pile, identified one historic homestead site with dugouts and a corral. This site is judged not eligible for inclusion in the National Register of Historic Places (NRHP) (CASA, 1986; Wildesen, 1986).

The Class III survey of 1120 ac (453 ha) in the vicinity of the processing site, which included the Rob Pit overburden pile, identified 11 archaeological sites and four isolated finds. Four of the 11 sites are campsites with associated artifacts and are considered eligible for the NRHP. The four prehistoric campsites are located along Johnson Wash and Lay Creek (CASA, 1986; Wildesen, 1986) and are in the vicinity of the two areas which will be cleaned up.

No cultural resource surveys have been conducted at the Rob Pit overburden pile or Maybell gravel source borrow sites. Due to the disturbed nature of these two areas, no cultural resources would be expected to occur.

\subsection{SOCIOECONOMICS}

The Maybell tailings site is located in a remote area in northwestern Colorado. The closest service center, county seat, and only city of size in Moffat County is Craig, approximately $25 \mathrm{mi}(40 \mathrm{~km})$ east of Maybell. Between 1970 and 1980 , the Moffat County population increased approximately 100 percent due to increases in oil and gas exploration, coal mining, and the construction of a large coal-fired electrical generating plant; virtually all of these increases occurred in Craig (Economic Development Commission, n.d.; Gibbons, 1986). By the early 1980 s, energy projects began declining and construction of the Colorado-Ute Power Plant just south of Craig was completed. Following the loss of these projects and general decline in the energy industry, large out-migrations of people occurred in Moffat County. The 1980 census reported a population of 13,133 in Moffat County and 8133 in Craig (DOC, 1980). The 1990 census reported a population of 11,357 in Moffat County and 8091 in Craig (DOC, 1991). From 1980 to 1990 , Moffat County had a population decrease of 13.5 percent and Craig had a population decrease of 0.5 percent. Maybell's population, which also includes area ranches, has remained relatively stable; it is currently estimated to have approximately 100 residents (Moch, 1992; Johnson, 1986). 
The 1990 census reported a total of 5235 housing units in Moffat County, of which 4178 were occupied and 1057 were vacant. Of the 5235 Moffat County housing units, 3559 are located in Craig. Craig had 3005 occupied housing units and 554 vacant housing units (DOC, 1991).

Historically, agriculture and mining have been the primary activities in Moffat County; however, by the early 1980 s, employment data indicated that retail trade, government, and mining were the primary sources for employment in the county. In Craig, long-term coal mining leases within and adjacent to the Moffat County form the basis for a major source of employment. Operation of the Colorado-Ute Power Plant is another significant employer in Craig. There are no currently proposed projects for Moffat County or the city of Craig that would affect employment patterns (Moch, 1990).

The countywide, average unemployment has decreased since its peak of 13.7 percent in 1983 and 1984 , but still remains high at 7.3 percent (1991) as compared to an average 1991 state of Colorado unemployment rate of 5 percent. The 1991 average Moffat County labor force was 4934 , with 4574 employed, and 360 unemployed. Statistics specific to Craig are unavailable; however, the county unemployment rate should also reflect the rate at Craig. According to the job service in Craig, there are experienced truck drivers and heavy equipment operators who are currently unemployed and available for temporary jobs (Kropinak, 1992).

Schools in Moffat County are considered to be operating close to capacity at this time. The school in Maybell contains two rooms for grades one through eight. Craig has three elementary schools, one middle school, and one high school (Estey, 1992).

Craig has a single, 42-bed licensed hospital. Current use is 10 to 12 beds per day. Both outpatient and emergency services are available at the hospital (Tar, 1990). There are also several private health clinics in Craig. County ambulance service is coordinated by the State Highway Patrol. Maybell has its own ambulance with Emergency Medical Technician-certified drivers (Johnson, 1986).

Craig has its own city police force. County areas, including Maybell, are patrolled by the county Sheriff's Department. Maybell has its own resident deputy on duty $\mathbf{4 0}$ hours per week. Additional coverage is provided by the resident deputy in Dinosaur, Colorado $(57 \mathrm{mi}[92 \mathrm{~km}]$ away), and deputies from Craig (Hettinger, 1986; Johnson, 1986).

Fire protection is available through a volunteer fire department in Maybell (May, 1992). 


\subsection{TRANSPORTATION}

The Maybell tailings site is approximately $2 \mathrm{mi}(3 \mathrm{~km})$ north of U.S. Highway 40 . Primary access to the site is by County Road 53 N. U.S. Highway 40 is a main east-west highway corridor in northwestern Colorado that accesses Denver to the east and continues west into Utah. Daily traffic counts just east of the village of Maybell averaged 640 vehicles of all types (Meyers, 1990). This paved, two-lane highway is rated at level of service "A." A rural route with this rating is projected to carry between 1750 to 1800 vehicles per hour without congestion (Peterson, 1986).

Three locations have been evaluated and proposed as sources of riprap borrow materials for the remedial action. All three locations were once, or are still operational. The potential haul routes are described below.

Potential access to the Maybell gravel source borrow site from the tailings site may be via an unnamed private road for $4 \mathrm{mi}(6.4 \mathrm{~km})$ to U.S. Highway 40 , then $3 \mathrm{mi}(4.8 \mathrm{~km})$ west to an unimproved road, and then $1 \mathrm{mi}(1.6 \mathrm{~km})$ north up this road to the borrow site. The unimproved road currently is assumed to be used infrequently.

Potential access to the Juniper Mountain Limestone Quarry from the tailings site may be via an unpaved private road for $4 \mathrm{mi}(6.4 \mathrm{~km})$ to U.S. Highway 40 , then west $1.5 \mathrm{mi}(2.4 \mathrm{~km})$, then south on a paved county road for $2.5 \mathrm{mi}(4 \mathrm{~km})$, and east for $1.3 \mathrm{mi}(2 \mathrm{~km})$ on a dirt access road to the borrow site. The private road that may be used from the tailings site to U.S. Highway 40 currently has a gate that is closed just north of U.S. Highway 40 . It is assumed that the private road and the unimproved dirt roads are used infrequently.

Potential access to the Craig Basalt Quarry from the tailings site may be via an unpaved private road for $4 \mathrm{mi}(6.4 \mathrm{~km})$ to U.S. Highway 40 , east on U.S.

Highway 40 for approximately $23 \mathrm{mi}(37 \mathrm{~km})$ to Craig, south $1.25 \mathrm{mi}(2 \mathrm{~km})$ on Colorado Highway 394 to a junction, then east and south on Colorado Highway 394 past the Craig Airport for approximately $7 \mathrm{mi}(11 \mathrm{~km})$ to Colorado Highway 100 , and west on Colorado Highway 100 for $1 \mathrm{mi}(1.6 \mathrm{~km})$ on the access road to the borrow site. 


\subsection{ENVIRONMENTAL IMPACTS}

\subsection{INTRODUCTION}

The environmental impacts of the proposed action and no action alternative are discussed in this section. Although some of the assumptions upon which the analyses were based may change, the impacts presented in the following sections represent a realistic upper limit for the severity of the impacts that may occur.

The 19-month remedial action work schedule includes a 5-month winter shutdown period. The first month of the remedial action would consist of project mobilization. During months 2 through 7,2 months of site preparation is initiated and completed, existing roads are upgraded, and all contaminated materials would be excavated and placed onto the existing tailings pile. Months 8 through 12 represent the winter shutdown. Months 12 through 19 would involve cover construction, erosion protection, and restoration activities. Peak employment would be 112 workers, with an average employment of 59 workers.

\subsection{NO ACTION ALTERNATIVE}

The no action alternative would not involve any remedial action and would not affect most of the environmental resources described in Section 3.0, "Affected Environment." Dispersion of the tailings by wind and water erosion would continue to contaminate lands adjacent to the piles. Other environmental resources (e.g., air quality) would be affected only slightly by no action. Therefore, this section does not include detailed analyses of the impacts of no action on the resources that would remain unaffected.

The no action alternative would impact public health. It would result in total health effects (i.e., fatal cancers) to the general population that are an order of magnitude higher than health effects following stabilization in place. Impacts due to no action would primarily result from the release of radon from the tailings pile and contaminated soils into the atmosphere, with consequent off-site dispersion of radon progeny. Airborne particulates would contribute insignificant health effects of approximately $1.7 \times 10^{-7}$ per year, and no health effects from gamma exposure would occur due to the distance of the general population from the Maybell site.

Excess health effect calculations for the no action alternative assumed that the tailings would not be dispersed by natural erosion or human activities in the future, since there is no way to accurately predict the rate of dispersion. However, some level of dispersion would occur over time; therefore, the actual excess health effects from the no action alternative could be greater than $1.2 \times 10^{-4}$ per year, and would continue to increase indefinitely without remedial action. As shown in Table 4.1, the general public excess health 
Table 4.1 Excess health effects for the general public and remedial action workers ${ }^{a}$

\begin{tabular}{lcccc}
\hline & $\begin{array}{c}\text { Radon decay } \\
\text { products } \\
\text { exposure } \\
\left(\times 1^{-4}\right)\end{array}$ & $\begin{array}{c}\text { Gamma } \\
\text { Exposure } \\
\left(\times 10^{-4}\right)\end{array}$ & $\begin{array}{c}\text { Airborne } \\
\text { radioactive } \\
\text { particulates } \\
\left(\times 10^{-4}\right)\end{array}$ & $\begin{array}{c}\text { Total excess } \\
\text { health effects } \\
\left(\times 10^{-4}\right)\end{array}$ \\
\hline $\begin{array}{l}\text { General public } \\
\text { Proposed action }\end{array}$ & 0.65 & 0 & 0 & 0.65 \\
No actionc & 1.2 & 0 & 0 & 1.2 \\
Remedial action workers & 14 & 0.9 & 0 & 37 \\
Proposed action & 0 & 0 & 16 & 0 \\
No action & 0 & 0.9 & 0 \\
\hline
\end{tabular}

an excess health effect of $10^{-4}$ or 0.0001 corresponds to 1 chance in 10,000 of an individual contracting a fatal cancer per year of exposure. Excess health effects (i.e., cancer fatalities) due to the proposed action were calculated for a typical remedial action scenario and schedule using standard Gaussian dispersion calculations and applicable risk coefficients found in BEIR IV (NAS/NRC, 1988) and BEIR $V$ (NAS/NRC, 1990) to determine risks from radiation exposure. A differential remedial action scenario and/or schedule would result in a different, but very similar, number of excess health effects.

bThe excess health effects from airborne radioactive particulates and gamma exposure for no action were determined to be negligible due to the large distance $(2.9 \mathrm{mi}[4.7 \mathrm{~km}])$ between the site and the nearest residences.

CThe excess health effects for no action are for a 19-month period to allow a direct comparison with the excess health effects due to 19 months of remedial action. The 19-month remedial action period includes one 5-month winter shutdown. 
effects from no action are greater when compared to those from remedial action.

The annual risk to an individual of the general population consuming muscle tissue from cattle that feed in Johnson Wash is calculated to be $2.4 \times 10^{-6}$. This value corresponds to a 1 -in-420,000 chance of experiencing excess health effects. This risk is less than the acceptable annual limit established by the International Commission on Radiological Protection (ICRP, 1981).

Finally, selection of the no action alternative would not be consistent with the intent of Congress in the UMTRCA (PL 95-604) and would not result in compliance with the EPA-proposed ground water protection and cleanup standards (52 FR 36000 and 40 CFR 192).

\subsection{PROPOSED ACTION}

\subsubsection{Radiation impacts}

The following is a discussion of radiation exposure pathways and the excess health effects to the general public that would result during and after the remedial action. Excess health effects to workers during remedial action are also discussed.

\section{Exposure pathways}

There are five principal radiological pathways by which individuals could be exposed during remedial action. These are: 1 ) inhalation of radon and radon progeny, 2) direct exposure to gamma radiation, 3) inhalation and ingestion of airborne radioactive particulates, 4 ) ingestion of contaminated foods produced in areas contaminated by tailings, and 5 ) ingestion of ground water and surface waters contaminated with radioactive materials.

The ingestion of contaminated food (pathway No. 4 above) and water (pathway No. 5 above) are not of significant concern as exposure pathways to the general public or site workers at the Maybell processing site, since no drinking water supply wells or agricultural fields have been adversely affected. However, the consumption of contaminated surface water and vegetation in Johnson Wash by livestock may occur and is discussed.

Excess health effects for the general public were calculated only for the inhalation of radon and radon progeny (pathway No. 1 above) and inhalation of airborne radioactive particulates (pathway No. 3 above). No exposures to the general public from direct gamma radiation (pathway No. 2 above) occur, because the nearest persons are $2.9 \mathrm{mi}(4.7 \mathrm{~km})$ southwest of the tailings site and elevated gamma radiation diminishes to background levels within a few hundred yards from the site. 
Excess health effects for site workers were calculated for the inhalation of radon and radon progeny (pathway No. 1 above), direct exposure to gamma radiation (pathway No. 2 above), and inhalation of airborne radioactive particulates (pathway No. 3 above).

\section{Health effects during remedial action}

Total excess health effects per year of exposure to the general population decreased from an estimated $1.2 \times 10^{-4}$ for no action to $6.5 \times 10^{-5}$ during remedial action, as shown in Table 4.1. Airborne particulates and gamma exposure do not contribute to the total health effects to the general population since the nearest residents are $2.9 \mathrm{mi}(4.7 \mathrm{~km})$ away. Implementation of the proposed action would reduce excess health effects for members of the general population from approximately 1 chance in 8300 to 1 chance in 15,400 for the 19 -month construction period. This value is calculated based on a general population of 125 .

Excess worker health effects are calculated to be $6.9 \times 10^{-4}$ from gamma exposure, or one chance in 1450 of a health effect resulting from exposure during remedial action. Excess health effects to workers from exposure to airborne particulates during remedial action are calculated to be $1.6 \times 10^{-3}$, or one chance in 625. The combined calculated doses of 46 millirems (mrem) ( 0.46 millisieverts [mSv]) from gamma exposure and $92 \mathrm{mrem}(0.92 \mathrm{mSv})$ from particulates would be less than 3 percent of the $5000-\mathrm{mrem}(50 \mathrm{mSv})$ standard established by the NRC in 10 CFR 20.1201 for radiation workers. Excess health effects from radon progeny exposure of remedial action workers was estimated to be $1.4 \times 10^{-3}$, or one chance in 714 . The total risk for workers from all pathways evaluated corresponds to a one in 270 chance of an excess health effect. The remedial action worker excess health effects calculations are based on a worker population of 40 .

\section{Health effects following remedial action}

Following remedial action, radon releases from the tailings pile and contaminated soils would be reduced by consolidating all contaminated materials and covering them with a compacted radon barrier. The radon cover would eliminate health effects to the general population from gamma exposures or airborne particulates. Total individual excess health effects following stabilization in place is estimated to be $9.9 \times 10^{-6}$ per year. For the assumed affected population of 125 persons within a $6-\mathrm{mi}(10-\mathrm{km})$ radius of the tailings site, this corresponds to a risk of 1 chance in 1440 for an individual to contract a fatal cancer over a 70-year lifetime.

\section{Health effects from Johnson Wash and Lay Creek}

Due to the relatively low radionuclide concentrations in the surface sediments, limited access, costly excavation and diversion of Lay Creek, and potential environmental damage to wetland areas, supplemental surface cleanup 
standards would be applied to the majority of contamination within the two drainages.

Consumption of meat from cattle grazing in Johnson Wash may be of concern, since this problem has been identified in other uranium mining and milling areas (Lapham et al., 1986; Millard et al., 1986). The total effective 50-year dose commitment to an individual consuming muscle tissue from cattle, which feed in Johnson Wash, is calculated to be 6 mrem (0.06 mSv) per year of ingestion, assuming 172 pounds (78 kilograms) as the U.S. per capita annual average meat consumption (Lapham et al., 1986). This dose would correspond to an annual risk of $2.4 \times 10^{-6}$, or one chance in 420,000 , of contracting a fatal cancer. This risk is less than the acceptable annual limit of one excess death per 100,000 individuals established by the International Commission on Radiological Protection (ICRP, 1981).

\subsubsection{Air quality impacts}

The proposed remedial action would involve the construction of an aboveground disposal cell, earthwork to clean up contaminated areas and provide erosion control, and the hauling of borrow materials from off-site locations. An increase in the concentrations of the air pollutants carbon monoxide, hydrocarbons, and total suspended particulates (TSP) in the disposal site area is expected due to heavy equipment operation and increased traffic on local highways from commuting site workers and haul trucks. The expected air pollutant concentration increases would occur only during the 14 months of active site work.

Fugitive dust (TSP) from wind erosion and movement of borrow materials along the haul roads would be the major pollutant. The DOE has addressed this issue by requiring the construction subcontractor to perform the remedial action within the framework of a proactive dust suppression plan. The construction subcontractor would be required to prepare a plan for approval by the Colorado Department of Health, Air Pollution Control Division, that includes monitoring of TSP concentrations, as well as the radionuclide concentrations of nuisance dust.

Dust generated by excavation, vehicle use, temporary materials stockpiling, and other activities would be controlled by use of water and approved water-based surfactants sprayed from hoses or trucks. Covering the haul trucks or using water on their contents would reduce dust during transportation of borrow materials. Dust control measures (i.e., water sprays) are assumed to be $\mathbf{5 0}$ percent effective in reducing fugitive emissions (CDPHE, 1981).

Prior to remedial action, the contractor would establish background levels. Once work is in progress, the contractor would monitor for fugitive dust by collecting 24-hour samples every 3 days. Colorado standards require that TSP concentrations be below 0.08 grains per cubic foot (150 micrograms per cubic meter). If it is determined that fugitive dust levels are exceeding state 
standards, work would be stopped and measures implemented to meet standards. The schedules for spraying the roads and pile areas would vary daily and would be determined on an hour-by-hour basis. The frequency of dust suppression activities would increase when combinations of low soil moisture and high wind speed are encountered.

In summary, air quality impacts resulting from the remedial action are expected to be minimal. Implementation of a proactive dust suppression plan, establishment of a fugitive dust monitoring program, and adherence to all applicable air quality regulations would minimize adverse impacts.

\subsubsection{Mineral resources and soils impacts}

The use of the Maybell site for stabilization in place of the tailings and other contaminated materials would not necessarily preclude future development of any mineral or oil and gas resources beneath the site. The UMTRCA (PL 95-604) requires that the mineral rights be transferred to the federal government along with the disposal site.

The proposed remedial action would result in the consumption of borrow materials such as soil, gravel, and rock. The use of soils from the Rob Pit overburden pile adjacent to the disposal site would not impact undisturbed natural areas. The consumption of borrow materials from off-site sources includes gravel from the Maybell gravel source, and the consumption of rock from the Craig Basalt Quarry and the Juniper Mountain Limestone Quarry. These borrow sites have previously been used as sources of borrow materials.

The Juniper Mountain Limestone Quarry is on BLM land on Juniper Mountain. The Craig Basalt Quarry is on private land but the minerals are owned by the federal government. The proposed action would remove a volume of materials from these two locations that might otherwise be sold to another user. If the materials were sold commercially, a royalty rate would be due to the United States. The DOE would be allowed the use of the material from these two sites under a Free-Use Permit, therefore, no royalty would be paid to the United States Treasury. This loss of royalty would not be a significant impact.

\subsubsection{Water resources impacts}

\section{Surface water}

Interpretation of the surface water data from Johnson Wash and Lay Creek suggests two conditions regarding surface water quality and the Maybell tailings site. First, the similarity of selected major ion values from Lay Creek, including those upstream and downstream of the confluence with Johnson Wash, suggests that high concentrations of sulfate and TDS which exceed EPA secondary drinking water standards (40 CFR 143) are a naturally occurring phenomenon in Lay Creek. Second, parameter values reported from Johnson Wash locations were less than the values reported for Lay Creek locations. This 
suggests that the contamination in Johnson Wash, even during major runoff events, will not degrade the surface water quality in Lay Creek. Therefore, cleaning up only the two areas along Johnson Wash and Lay Creek and leaving the remainder of the contamination would not impact surface water quality.

\section{Ground water}

The disposal option proposed for the Maybell tailings site involves stabilization in place of the existing tailings and associated contaminated materials. An aboveground disposal cell has been designed to reduce radon emanation, minimize infiltration of water, withstand differential settlement, resist degradation, and meet the proposed EPA ground water protection and cleanup standards (52 FR $36000)$. Design parameters of the proposed disposal cell have been evaluated in conjunction with the hydrogeologic and geochemical characteristics of the Maybell site. The consideration of ground water protection has included longterm seepage, transient drainage, and geochemical attenuation evaluations (DOE, 1994).

Background ground water quality in the Browns Park Formation aquifer is highly variable because of naturally occurring mineralization and localized oxidized conditions related to nearby mining activities. Concentrations of the EPA hazardous constituents in background ground water samples vary from below laboratory method reporting limits to several orders of magnitude above the proposed EPA standards.

Colorado has nearly $\mathbf{8 0 0}$ ground water sources used to supply potable water for public consumption. Nearly 780 of those ground water sources require no treatment beyond disinfection (Bodnar and Rogers, 1992). Of the approximately 20 remaining ground water sources, all require only a single treatment process (such as ion-exchange or reverse-osmosis) to reduce concentrations that exceed primary or secondary standards for a single ion. Thus, typical practice in Colorado, especially for small potable water supply systems, is to not treat ground water.

Most small Colorado municipalities that choose to treat ground water for a single problem constituent do so at minimal cost. Because of the number of constituents exceeding the EPA-proposed MCLs in the ground water from the Browns Park Formation aquifer at the Maybell site, multiple treatment technologies at greater expense would be necessary to reduce contaminant levels to drinking water standards.

The naturally occurring contamination cannot be cleaned up using water treatment methods reasonably employed in public water supply systems. Ground water in the Browns Park Formation is not a current or potential source of drinking water downgradient of the site. Although ground water is not currently used for livestock watering, implementation of the proposed remedial action would not preclude the future use of ground water for this purpose. 
Naturally occurring reducing geochemical conditions exist within the Browns Park Formation aquifer in the vicinity of the Maybell tailings site. These conditions have prevented contamination of ground water resulting from the tailings pile and other site activities downgradient of the existing tailings pile.

The need for restoration of ground water in the Browns Park Formation aquifer beneath the Maybell site will be evaluated during the ground water phase of the UMTRA Project. A monitoring program for evaluating performance of the completed Maybell disposal cell is addressed in other DOE documents. Disposal cell performance monitoring, which will include installation and sampling of new monitor wells immediately downgradient of the tailings site, is described in the remedial action plan (DOE, 1994) and will be discussed in detail in the long-term surveillance plan for the Maybell site.

\subsubsection{Flora and fauna impacts}

Remedial action activities would result in direct impacts, as described below, and minor indirect impacts on the flora and fauna associated with the Maybell site. Direct impacts would be the destruction of habitat during the cleanup of contaminated land, while indirect impacts associated with noise and human activities may reduce wildlife use in habitat adjacent to the direct impact zone. Indirect impacts would generally occur only during remedial action and are considered minor.

Implementation of the proposed action would result in the disturbance of approximately 270 ac (110 ha) of land. The areas that would be disturbed include the disposal site and associated windblown and waterborne contaminated areas, and the three off-site proposed borrow sites. However, past mining and processing activities have previously disturbed much of the land at and surrounding the tailings pile. Impacts to these areas are described below.

The three proposed off-site borrow locations contain disturbed land as they have been previously utilized for borrow materials. Therefore, impacts on flora and fauna from the proposed remedial action would be minimal and are not addressed in this EA.

Two plant community types in the vicinity of the disposal site would be impacted: 1) areas dominated by vegetation indicative of disturbed habitat (160 ac [65 ha]), and 2) desert shrub habitat dominated by big sagebrush. The largest segment of desert shrub habitat occurs in the windblown contaminated area and around the former mill site (70 ac [28 ha]).

Waterborne contamination is present in wetland habitat along Johnson Wash and Lay Creek. Approximately 9 ac (3.6 ha) of wetlands are contaminated in Johnson Wash and 22 ac ( 9 ha) are contaminated in Lay Creek. The DOE proposes to clean up only the two areas (Section 2.2.3) along Johnson Wash and Lay Creek, and apply supplemental surface cleanup standards to the remaining contamination. Therefore, none of the 31 ac (13 ha) of wetland 
habitat along Johnson Wash and Lay Creek would be impacted during the remedial action.

The clearing of contaminated land during the remedial action would constitute an unavoidable impact on vegetation and wildlife. The magnitude of this impact depends on the quantity and quality of habitat that would be impacted and the measures taken to restore this habitat. In terms of habitat quality for wildlife, the disturbed lands represent areas of least quality and desert shrub habitat represents habitat of higher quality.

Before surface-disturbing activities begin, a plan for restoring excavated areas would be determined by the DOE and the Remedial Action Contractor in consultation with the appropriate regulatory agency or other authority. Requirements for restoration typically include measures such as backfilling, recontouring, and revegetation. Impacts would be mitigated by starting restoration as soon as possible after completion of surface-disturbing activities.

\section{Game species}

Game species that would be impacted by remedial action activities include the mule deer, pronghorn antelope, and sage grouse. The approximate 214 ac $(87 \mathrm{ha})$ (tailings pile, mill yard area and windblown and waterborne contaminated areas) of land in the disposal site vicinity that would be cleared are equivalent to range used by 11 mule deer, assuming a density of 32 deer $\mathrm{mi}^{2}$ (12 deer km²) (CDOW, 1985a). The pronghorn antelope is common in the area, and it uses the processing site area, including the tailings pile. As with the mule deer, approximately 214 ac (87 ha) of wintering habitat for the pronghorn antelope would be lost, which is equivalent to the range used by three pronghorn antelope assuming a density of eight antelope per $\mathrm{mi}^{2}$ (three antelope per $\mathrm{km}^{2}$ ) (CDOW, 1985b). Sage grouse use the desert shrub habitat for brood habitat and year-round use; $113 \mathrm{ac}$ ( $46 \mathrm{ha}$ ) used by the sage grouse would be cleared in the tailings pile area.

Following remedial action, the 66 ac ( 27 ha) disposal cell would not be suitable habitat for most wildlife; the topslope and the sideslopes of the disposal cell would be covered by rock. The duration of the impact on game species due to the clearing of the land adjacent to the disposal cell would depend on the habitat restoration plan. Restoring the habitat to the desert shrub type would take 4 to 5 years, while creation of grass-dominated habitat would take about 2 years.

\section{Threatened and endangered species}

According to the FWS, seven federally listed threatened and endangered species have the potential to occur near the Maybell site (Rose, 1992). These seven species include the bald eagle, the black-footed ferret, the humpback chub, the bonytail chub, the razorback sucker, the Colorado squawfish, and the Ute ladies'-tresses. The black-footed ferret was judged not to occur at or near the 
site due to the lack of prairie dog towns. The humpback chub, bonytail chub, and razorback sucker were also judged not to occur at or near the site due to the lack of suitable aquatic habitat.

Remedial action activities at all the Maybell work sites are not expected to have a direct impact on the three threatened and endangered wildlife and plant species occurring in the site vicinity. The bald eagle is a winter resident and nests along the Yampa River. The closest nesting bald eagles are two pairs of birds, approximately $20 \mathrm{mi}(32 \mathrm{~km})$ east of the tailings site near Craig, Colorado. Activities at the Maybell gravel source along the Yampa River would not affect this species because use of the area by the bald eagle is minimal, no nesting pairs are in the vicinity, and because the borrow site would not be used during the 5-month winter shutdown period.

The Colorado squawfish occurs in the Yampa River, but excavation activities would not impact the river, and therefore would not impact the Colorado squawfish. However, since the Yampa River may be used as a source of water for construction activities (dust control and compaction water), this would result in a "may affect" determination on the threatened and endangered fish of the Colorado River Basin by the FWS. Under the Endangered Species Act of 1973 (PL 93-205), as amended, this determination requires formal consultation with the FWS. According to the "Recovery Implementation Program for Endangered Fish Species in the Upper Colorado River Basin" (FWS, 1987), water depletion subject to a "may affect" determination would require a one-time payment to the FWS for the quantity of water used for the remedial action. Mitigation for this impact will be the one-time payment by DOE to the FWS based on an estimated annual average of 29.5 ac-ft of water (TAC, 1991) for remedial action. These funds would be used to acquire water rights in the Upper Colorado River Basin and otherwise support the recovery of the endangered fish.

Potential habitat for the Ute ladies'-tresses occurs along Johnson Wash and Lay Creek, and possibly at the Maybell gravel source borrow site. The DOE proposes the application of supplemental surface cleanup standards to the wetland vegetation along Johnson Wash and Lay Creek. Therefore, the Johnson Wash and Lay Creek wetland habitats would not be impacted by the proposed remedial action. However, two field surveys for this species will be conducted at Johnson Wash and Lay Creek and the Maybell gravel source borrow site in 1994 using survey techniques prescribed by the FWS (FWS, 1992). If the supplemental surface cleanup standards application is turned down by the NRC or the Colorado Department of Health, and the Ute ladies'-tresses occur in the wetlands along Johnson Wash and/or Lay Creek, a mitigation plan would be formulated in consultation with the FWS.

Five federal candidate species were also listed by the FWS as possible inhabitants near the Maybell site. These five species include the loggerhead shrike, the northern goshawk, the Columbian sharp-tailed grouse, the flannelmouth sucker, and the Wetherill milkvetch. 
The loggerhead shrike occurs as a breeding species throughout most of Colorado, including the Maybell site area (Kingery and Graul, 1978). However, this species has declined in numbers steadily over most of its range, including Colorado. Wildlife surveys over the past 10 years have not recorded this species in the Maybell area (DOE, 1983; TAC, 1986a, 1987, 1989, 1990, 1992; Toolen, 1992). Therefore, the remedial action will not impact this species as it is unlikely that this species occurs at any of the work locations.

The northern goshawk is a year-round resident in northwest Colorado (Kingery and Graul, 1978). This species prefers mature conifer forests, habitat which is not present at the tailings site. Mature conifer forest habitat is present at only two of the proposed borrow sites; the Juniper Mountain Limestone Quarry and the Craig Basalt Quarry. Since both borrow sites are existing operations, any impacts to this species have already occurred. Additional impacts may occur if either of the two borrow sites need to be expanded in order to provide the necessary quantities of materials for remedial action. However, any additional impacts cannot be quantified at this time because it is not known if expansion of the sites is necessary, or if any conifer forest habitat would be impacted if expansion was necessary.

The Columbian sharp-tailed grouse has been reduced to remnant populations throughout most of its range. This species prefers a selected mountain shrub habitat which is not present at the Maybell site or the proposed borrow sites. The remedial action would not impact this species because it is unlikely that it occurs at any of the work sites due to the lack of suitable habitat.

The flannelmouth sucker occurs in the Yampa River (Wick et al., 1985). The only activity associated with the remedial action at the Maybell site that would take place near the Yampa River would be at the Maybell gravel source borrow site. Since remedial action activities at the Maybell gravel source would not impact the river, there would be no impacts on this species.

The Wetherill milkvetch is a perennial plant that is found in six counties in Colorado, including Moffat County. This species may occur in the sagebrush habitat near the tailings site. A field survey for this species in the tailings pile area was conducted in August 1993 using prescribed FWS (FWS, 1992) survey techniques. No populations of this species were found during the survey. The remedial action would not impact this species because it does not occur in the project area.

\subsubsection{Land use impacts}

The final restricted area would encompass approximately 165 ac (67 ha) and would be under the direct control of the federal government. The site would be permanently restricted from public access and development and any other use of this area would be permanently precluded. The UMTRCA (PL 95-604) requires that the mineral rights for the disposal site be transferred to the federal government along with the disposal site. It also authorizes the Secretary of the 
Interior, with the concurrence of the Secretary of Energy and the NRC, to dispose "of any subsurface mineral rights by sale or lease... if the Secretary of the Interior takes such action as the Commission deems necessary pursuant to the license issued by the Commission to assure [sic] that the residual radioactive materials will not be disturbed by reason of any activity carried on following such disposition" (PL 95-604).

The Rob Pit overburden pile would be disturbed during remedial action because it would be used as a source of construction material for the disposal cell. This overburden material originates from Rob Pit, which is located west of the overburden pile. The only activity that could affect Rob Pit would be if the water in the pit was used for construction of the disposal cell. At present, the source(s) of construction water has not been determined. If Rob Pit water is used, the DOE would avoid or mitigate any adverse impacts that would occur to the existing water pipeline and pump that are present at Rob Pit.

Approximately 370 ac (150 ha) of land within and adjacent to the existing tailings pile would be required for construction purposes. Already restricted from access are $110 \mathrm{ac}$ ( $45 \mathrm{ha}$ ) of the area required for construction. The DOE would obtain a Free-Use permit from the BLM for the temporary use of land under BLM administration.

The remedial action would disturb existing livestock grazing within the construction area for the length of the project. Cleanup of the area in Upper Johnson Wash and the area at the confluence of Johnson Wash and Lay Creek would also disturb livestock grazing. The DOE would financially compensate individuals whose BLM grazing allotment would be impacted by the remedial action.

Surface restoration would be performed for all disturbed areas within the 370-ac (150-ha) construction zone and at the two remediated areas along Johnson Wash and Lay Creek. As appropriate, uncontaminated fill material would be used as backfill, areas would be graded to promote surface drainage or to conform to existing drainage patterns, and all areas would be revegetated. Consultation with the BLM would occur to determine those plant species most suitable for revegetation in areas disturbed by the remedial action. Revegetation of disturbed areas would return the grass habitat to conditions suitable for grazing in about 2 years.

The Maybell gravel source, Juniper Mountain Limestone Quarry, and the Craig Basalt Quarry are all existing operations. It is assumed that they will all continue operation after being used for the Maybell remedial action project. Therefore, restoration of these sites is not considered for the proposed remedial action.

Although the Yampa River is outside of the proposed project area, the Maybell gravel source is a proposed borrow site which is located along the Yampa River. If the Maybell gravel source is used as a borrow site, excavation activities would 
not impact the Yampa River. Therefore, flatwater boating use of the Yampa River would not be impacted by the proposed remedial action.

The OHV recreation use of the overburden piles and pits in the vicinity of the Maybell tailings pile would be adversely impacted by the proposed remedial action. Access to the area via Moffat County Road $53 \mathrm{~N}$ would not be affected, but areas in the vicinity of the tailings pile would be restricted during the 19month project. Access to the Rob Pit overburden pile and use of the former mill site as an OHV-user parking/staging area would be prohibited because these locations are within the project area. Recreational OHV-user access to overburden piles and pits outside of the proposed project area should not be impacted by the remedial action. Access to these areas can be achieved via Moffat County Road $53 \mathrm{~N}$ before it enters the area to be restricted.

\subsubsection{Cultural resources impacts}

The four archaeological sites located along Johnson Wash and Lay Creek that are eligible for the NRHP should not be impacted by remediation of the two areas within these drainages. If a determination is made that any of the four sites would be impacted, or if any new sites are identified, remediation activities would be halted. Remediation activities would not proceed until the DOE has implemented a data recovery plan. Implementation of a data recovery plan by the DOE would be in conjunction with the Colorado State Historic Preservation Officer. A data recovery plan would also involve the BLM if the site was on land under their administration.

The proposed borrow sites have not been surveyed for cultural or historical resources. Due to the disturbed nature of the Maybell gravel source, no historic resources would be expected to occur. If quarrying of the Maybell gravel source borrow site requires expansion of the existing quarry pit, a cultural resource inventory would be conducted by the DOE of the expansion area. The Juniper Mountain Limestone Quarry and the Craig Basalt Quarry locations would be surveyed by the DOE for cultural and historic resources if they are selected for use.

\subsubsection{Socioeconomics impacts}

Impacts on population and employment were assessed by comparing the average and peak labor force requirements for the proposed action with the local availability of workers with suitable job skills and experience. Because the town of Maybell is so small, it was assumed that the majority of the work force would commute from Craig, while specialized or supervisory workers would likely come from outside the area.

The average work force is estimated at 59. Twelve of these workers would be supervisors or specialized technicians (e.g., radiological technicians) and the need for these jobs would remain constant during remedial action. The average general labor requirements (47 workers) would consist primarily of truck drivers, 
heavy equipment operators, operator supervisors, mechanics, and general laborers. Between 1 and 25 truck drivers and 10 to 38 heavy equipment operators would be needed during the remedial action. According to the local employment office in Craig, there should be an available supply of experienced truck drivers, heavy equipment operators, mechanics, and general laborers in the area (Kropinak, 1992). Utilization of the available work force would be a positive impact since unemployment levels in Moffat County would be reduced temporarily during the remedial action project.

Remedial action would have a direct positive impact on the local economy through wages and salaries paid to remedial action workers and expenditures for materials, supplies, and equipment. There would also be indirect positive impacts as these funds circulated throughout the economy. Indirect expenditures also would generate tax revenues, which would be available for local and state governmental use.

The estimated cost of the remedial action is approximately $\$ 12.4$ million; this cost does not include construction management. This cost is based upon the revised preliminary design for review cost estimate prepared July 1993 by the Remedial Action Contractor, Morrison Knudsen Corporation, Environmental Services Division. The benefits to the local economy would include wages and salaries, local contracts, and purchases or rentals of equipment, materials, and supplies. Materials and supply purchases would include the supplies for overhead, some rock materials, fencing, and miscellaneous purchases for fuel, tools, equipment repair, and the like.

A positive impact from the remedial action is related to monies spent locally and within the state of Colorado. An estimated $\$ 6.1$ million would be attributed to wages, consumable materials (e.g., rock borrow), and nonconsumable materials (e.g., fencing) that would be purchased locally or attributed to area employment.

\subsubsection{Transportation impacts}

Activities associated with the proposed action would primarily require use of existing dirt roads to access the disposal site. Some use of U.S. Highway 40 would also occur, however, for transporting gravel from the Maybell gravel source and rock from the Craig Basalt Quarry and the Juniper Mountain Limestone Quarry. Workers commuting to work sites would also add to existing traffic on U.S. Highway 40.

Since existing use of the dirt roads to access U.S. Highway 40 from the borrow sites is considered low (i.e., use is occasional by area hunters, land managers, or recreationists), trips on these roads related to remedial action were not considered further.

Use of U.S. Highway 40 would increase by a maximum of 89 percent (from 640 vehicles per day to 1207 vehicles per day) during a 4-month period following the winter shutdown (second construction season). This increased use would 
consist of trucks hauling gravel materials from the Maybell gravel source, and trucks hauling large rock from the Craig Basalt Quarry and the Juniper Mountain Limestone Quarry. A stretch of $2.8 \mathrm{mi}$ would be affected between Maybell and the unnamed access road to the east of Maybell. Daily worker commute trips and miscellaneous contractor trips would be largely east of this road segment and would constitute a minor impact on existing use. Since U.S. Highway 40 in the vicinity of Maybell has an average daily traffic of 640 vehicles of all types (Meyers, 1990) and is rated to safely carry 1750 to 1800 vehicles per hour (Peterson, 1986), increases related to remedial action would not affect the level of service for U.S. Highway 40.

\subsubsection{Noise impacts}

An increase in noise in the Maybell area and along the haul routes to the off-site borrow locations is expected during the remedial action. The noise increase would be due to heavy equipment operation at the site and at the three proposed off-site borrow locations, and from commuting site workers. However, this increase would occur only during the 14 months of active site work.

Since the Maybell site is in a remote area, the greatest noise impact would not be associated with site activities but rather with the transportation of borrow materials. The greatest noise impacts would be experienced by residents along the haul routes to the borrow sites and those living near the borrow sites. These noise impacts would be limited to weekdays.

Noise levels in Colorado are regulated through city, county, state, and federal noise statutes. Although no sound measurements have been taken at any of the work locations, the DOE may evaluate noise levels at these areas and the selected haul roads to the borrow sites on a weekly basis once remedial action is underway. The DOE would require the subcontractor performing the remedial action to comply with all applicable noise statutes. 


\subsection{MITIGATIVE MEASURES}

The following mitigative measures were incorporated into the remedial action plan to reduce the environmental impacts:

- A one-time payment of $\$ 11.98$ (or the most current amount, which is adjusted annually for inflation) per acre-foot from the DOE to the FWS for the estimated annual average of 29.5 ac-ft of water used for construction. This payment would provide mitigation for the water depletion of the Upper Colorado River Basin and its "may affect" determination for threatened and endangered fish. These funds would be used to acquire water rights and otherwise support the recovery of the endangered fish of the Upper Colorado River Basin. 


\subsection{AGENCIES AND PERSONS CONSULTED}

\begin{tabular}{|c|c|c|}
\hline Agency & Person & Subject \\
\hline $\begin{array}{l}\text { City Hall } \\
\text { Craig, Colorado }\end{array}$ & Jackie Moch & Economics \\
\hline $\begin{array}{l}\text { Colorado Department of Public } \\
\text { Health and Environment, } \\
\text { Engineering Department } \\
\text { Denver, Colorado }\end{array}$ & $\begin{array}{l}\text { Glen Bodnar } \\
\text { David Rogers }\end{array}$ & $\begin{array}{l}\text { Potable water supplies and } \\
\text { treatment technologies }\end{array}$ \\
\hline $\begin{array}{l}\text { Colorado Department of } \\
\text { Highways, Division of Highways } \\
\text { Denver, Colorado }\end{array}$ & $\begin{array}{l}\text { Larry Meyers } \\
\text { Charles Peterson }\end{array}$ & Transportation \\
\hline $\begin{array}{l}\text { Colorado Division of } \\
\text { Employment and Training, Craig } \\
\text { Job Services Center } \\
\text { Craig, Colorado }\end{array}$ & $\begin{array}{l}\text { Kandance Kropinak } \\
\text { Kathy Shea }\end{array}$ & Economics \\
\hline $\begin{array}{l}\text { Colorado Division of Wildlife } \\
\text { Ft. Collins, Colorado }\end{array}$ & $\begin{array}{l}\text { Jerry Creig } \\
\text { Clait Braun }\end{array}$ & $\begin{array}{l}\text { Threatened and endangered } \\
\text { raptors, sage grouse } \\
\text { Threatened and endangered } \\
\text { fish, Yampa River and Lay } \\
\text { Creek }\end{array}$ \\
\hline $\begin{array}{l}\text { Colorado Division of Wildlife } \\
\text { Grand Junction, Colorado }\end{array}$ & $\begin{array}{l}\text { Van Grahm } \\
\text { Pat Martinez }\end{array}$ & $\begin{array}{l}\text { Game species } \\
\text { Lay Creek fish }\end{array}$ \\
\hline $\begin{array}{l}\text { Colorado Division of Wildlife } \\
\text { Maybell, Colorado }\end{array}$ & $\begin{array}{l}\text { Kirk Navo } \\
\text { Brad Petch }\end{array}$ & $\begin{array}{l}\text { Sage grouse, threatened and } \\
\text { endangered species, } \\
\text { waterfowl, nongame wildlife }\end{array}$ \\
\hline $\begin{array}{l}\text { Colorado Historical Society } \\
\text { Denver, Colorado }\end{array}$ & Leslie Wildesen & Cultural resources inventory \\
\hline $\begin{array}{l}\text { Colorado Natural Areas Program } \\
\text { Denver, Colorado }\end{array}$ & Steve O'Kane & $\begin{array}{l}\text { Threatened and endangered } \\
\text { plants }\end{array}$ \\
\hline $\begin{array}{l}\text { Craig Volunteer Fire District } \\
\text { Craig, Colorado }\end{array}$ & Butch Holmes & Socioeconomics \\
\hline $\begin{array}{l}\text { Craig Water and Sewage } \\
\text { Treatment Plant } \\
\text { Craig, Colorado }\end{array}$ & Tim Klinetobe & Socioeconomics \\
\hline $\begin{array}{l}\text { Department of Social Services } \\
\text { Craig, Colorado }\end{array}$ & Debbie Davidson & Socioeconomics \\
\hline $\begin{array}{l}\text { Moffat County Auditor } \\
\text { Craig, Colorado }\end{array}$ & Jack Bonaker & Socioeconomics \\
\hline
\end{tabular}




\begin{tabular}{|c|c|c|}
\hline Agency & Person & Subject \\
\hline $\begin{array}{l}\text { Moffat County Planning } \\
\text { Department } \\
\text { Craig, Colorado }\end{array}$ & Richard Gibbons & Economics \\
\hline $\begin{array}{l}\text { Moffat County School District } \\
\text { Craig, Colorado }\end{array}$ & Shirley Snare & Socioeconomics \\
\hline $\begin{array}{l}\text { Moffat County Sheriff's } \\
\text { Department } \\
\text { Craig, Colorado }\end{array}$ & $\begin{array}{l}\text { Nancy Hellinger } \\
\text { Jack May } \\
\text { Bruce Johnson }\end{array}$ & Socioeconomics \\
\hline $\begin{array}{l}\text { The Memorial Hospital } \\
\text { Craig, Colorado }\end{array}$ & $\begin{array}{l}\text { Nancy Bard } \\
\text { Lou Tar }\end{array}$ & Socioeconomics \\
\hline Umetco/Union Carbide & Jack Frost & $\begin{array}{l}\text { Maybell mill site, future plans, } \\
\text { claims }\end{array}$ \\
\hline $\begin{array}{l}\text { U.S. Army Corps of Engineers } \\
\text { Grand Junction, Colorado }\end{array}$ & $\begin{array}{l}\text { Nick Mezei } \\
\text { Gary Davis }\end{array}$ & Wetlands \\
\hline $\begin{array}{l}\text { U.S. Bureau of Land } \\
\text { Management } \\
\text { Craig, Colorado }\end{array}$ & $\begin{array}{l}\text { Mike Albee } \\
\text { Dave Hillberry } \\
\text { Roy Jackson } \\
\text { Ole Olsen } \\
\text { John Husband }\end{array}$ & $\begin{array}{l}\text { Wildlife } \\
\text { Land use, grazing leases } \\
\text { Land use } \\
\text { Revegetation } \\
\text { Minerals, oil and gas leases }\end{array}$ \\
\hline $\begin{array}{l}\text { U.S. Bureau of Land } \\
\text { Management } \\
\text { Glenwood Springs, Colorado }\end{array}$ & Leonard Colemen & $\begin{array}{l}\text { Threatened and endangered } \\
\text { plant species }\end{array}$ \\
\hline $\begin{array}{l}\text { U.S. Fish and Wildlife Service } \\
\text { Salt Lake City, Utah }\end{array}$ & Mike Lockhart & Raptors \\
\hline $\begin{array}{l}\text { U.S. Fish and Wildlife Service } \\
\text { Salt Lake City, Utah }\end{array}$ & $\begin{array}{l}\text { Larry England } \\
\text { Robert Ruesink }\end{array}$ & $\begin{array}{l}\text { Threatened and endangered } \\
\text { plants } \\
\text { Threatened and endangered } \\
\text { species }\end{array}$ \\
\hline $\begin{array}{l}\text { U.S. Soil Conservation Service } \\
\text { Meeker, Colorado }\end{array}$ & Gary Noller & Revegetation \\
\hline
\end{tabular}


LIST OF PREPARERS

\begin{tabular}{|c|c|c|}
\hline Person & Organization & Responsibility \\
\hline Sandra Beranich & Jacobs-Weston & $\begin{array}{l}\text { Socioeconomics, transportation, } \\
\text { land use }\end{array}$ \\
\hline Charles Burt & Jacobs-Weston & $\begin{array}{l}\text { Threatened and endangered species, } \\
\text { weather, wetlands, wildlife }\end{array}$ \\
\hline George Hartmann & Jacobs-Weston & Engineering \\
\hline Mary Beth Leaf & Jacobs-Weston & $\begin{array}{l}\text { Cultural and archaeological } \\
\text { resources }\end{array}$ \\
\hline Gerry Lindsey & Jacobs-Weston & Mineral resources, geology, soils \\
\hline Mark D. Hansen & Jacobs-Weston & Document coordinator, air quality \\
\hline John McBee & Jacobs-Weston & Site manager \\
\hline Debora Anderson & Jacobs-Weston & Editing \\
\hline Erik Storms & Jacobs-Weston & Ground water hydrology \\
\hline Linda Ulland & Jacobs-Weston & $\begin{array}{l}\text { Technical Assistance Contractor } \\
\text { Regulatory Compliance manager }\end{array}$ \\
\hline $\begin{array}{l}\text { Cheryl Slosberg } \\
\text { Linda Keith }\end{array}$ & Jacobs-Weston & Word processing \\
\hline $\begin{array}{l}\text { James Brannan } \\
\text { Liz Wagner }\end{array}$ & Jacobs-Weston & Graphics \\
\hline
\end{tabular}




\subsection{REFERENCES}

BFEC (Bendix Field Engineering Corporation), 1985. Radiologic Characterization of the Maybell, Colorado, Uranium Mill Tailings Remedial Action Site, GJ-39, prepared by BFEC, Grand Junction, Colorado, for the U.S. Department of Energy, UMTRA Project Office, Albuquerque Operations Office, Albuquerque, New Mexico.

Berry, J. D., and R. L. Eng, 1985. "Interseasonal Movements and Fidelity to Seasonal Use Areas by Female Sage Grouse," Journal of Wildlife Management, Vol. 49, No. 1, pp. 237-240.

Bodnar, G., and D. Rogers, 1992. Colorado Department of Public Health and Environment, Engineering Department, Denver, Colorado, personal communication to Jim Crain, Engineering Services, Jacobs Engineering Group Inc., Albuquerque, New Mexico, October 1992.

Bunin, J. E., 1992. "Status Report for Astragalus wetherillii," U.S. Fish and Wildlife Service, Golden, Colorado.

CASA (Complete Archaeological Service Associates), 1986. "Cultural Resource Inventory, Maybell UMTRA Site, Moffat County, Colorado," prepared for Jacobs Engineering Group Inc., Albuquerque, New Mexico.

CDPHE (Colorado Department of Public Health and Environment), 1990. The Basic Standards for Ground Water, Water Quality Control Commission, Section 3.11.0 (5 CCR 1002-8), Table 3 Agricultural Standards, as amended, effective October 30, 1990, Denver, Colorado.

CDPHE (Colorado Department of Public Health and Environment), 1981. Fugitive Dust Emissions, Air Pollution Control Division, Denver, Colorado.

CDOW (Colorado Division of Wildlife), 1986a. "Lay Quadrangle, Mule Deer Activity Areas," Colorado Division of Wildlife, Grand Junction, Colorado (Map).

CDOW (Colorado Division of Wildlife), 1986b. "Lay Quadrangle, Pronghorn Activity Areas," Colorado Division of Wildlife, Grand Junction, Colorado (Map).

CDOW (Colorado Division of Wildlife), 1985a. "Results of the 1985 DAU D-Z Aerial Deer Quadrant Census," Colorado Division of Wildlife, Grand Junction, Colorado.

CDOW (Colorado Division of Wildlife), 1985b. "Wildlife Resource Inventory SystemScenario, Pronghorn Antelope Inventory System, Data Analysis Unit PA34," Colorado Division of Wildlife, Grand Junction, Colorado.

CDOW (Colorado Division of Wildlife), 1983a. "Wildlife Resource Information SystemScenario, Mule Deer Data Analysis Unit D-2, Game Management Units 3, 4, 441,5 , and 14," Colorado Division of Wildlife, Grand Junction, Colorado. 
CDOW (Colorado Division of Wildlife), 1983b. "Wildlife Resource Information SystemScenario, Pronghorn Antelope Data Analysis Unit PA 10, Antelope Management Unit 45," Colorado Division of Wildlife, Grand Junction, Colorado.

DOC (U.S. Department of Commerce), 1991. Population and Housing, Summary of Population and Housing Characteristics, Colorado, July 1991, Bureau of the Census, U.S. Government Printing Office (GPO), Washington D.C.

DOC (U.S. Department of Commerce), 1980. General Population Characteristics: Colorado 1980, PC 80-1-B7, Tables 14-15, Bureau of the Census, U.S. Government Printing Office (GPO), Washington D.C.

DOE (U.S. Department of Energy), 1994. Remedial Action Plan and Site Design for Stabilization of the Inactive Uranium Mill Tailings Site, Maybell, Colorado, DOE/AL/62350-24F, Revision 0, final, June 1994, U.S. Department of Energy, Uranium Mill Tailings Remedial Action Project, Albuquerque, New Mexico.

DOE (U.S. Department of Energy), 1990. Maybell Radon Monitoring: Pre-Remedial-Action Summary, monitoring period: April 27, 1989, through June 6, 1990, file location number 14.17.3.5, August 1990, U.S. Department of Energy, Uranium Mill Tailings Remedial Action Project, Albuquerque, New Mexico.

DOE (U.S. Department of Energy), 1989. "Technical Approach Document," UMTRADOE/AL 050425.0002, Revision II, December 1989, Uranium Mill Tailings Remedial Action Project, Albuquerque, New Mexico.

DOE (U.S. Department of Energy), 1983. "Environmental Assessment of Remedial Actions on the Uranium Mill Tailings at the Maybell Site, Moffat, County, Colorado," DOE/EA-0347, August 1983, DOE UMTRA Project Office, Albuquerque Operations Office, Albuquerque, New Mexico.

Dunn, P. O., and C. E. Braun, 1986. "Late Summer-Spring Movements of Juvenile Sage Grouse," Wilson Bulletin, Vol. 98, No. 1, pp. 83-92.

Economic Development Commission, n.d. "City of Craig Economic Profile," City of Craig Economic Commission, Craig, Colorado.

EG\&G (Edgerton, Germerhausen, and Grier; Energy Measurements Group), 1982. An Aerial Radiological Survey of the Area Surrounding the Maybell Site, Maybell, Colorado, EG\&G Survey Report EP-U-017, prepared by EG\&G, Las Vegas, Nevada.

Estey, T., 1992. Moffat County School District Office, Craig, Colorado, personal communication to Sandra Beranich, Environmental Services Department, Jacobs Engineering Group Inc., Albuquerque, New Mexico, September 11, 1992. 
FBDU (Ford, Bacon \& Davis Utah Inc.), 1981. Engineering Assessment of Inactive Uranium Mill Tailings, Maybell Site, Maybell, Colorado, DOE/UMT-0116, FBDU 360-11, UC 70, September 1981, prepared by FBDU, Salt Lake City, Utah, Contract No. DE-AC04-76GJ01658, for the U.S. Department of Energy, Albuquerque Operations Office, Uranium Mill Tailings Remedial Actions Project Office, Albuquerque, New Mexico.

FBDU and SNL (Ford, Bacon \& Davis Utah Inc. and Sandia National Laboratories), 1982. Environmental Assessment of Remedial Actions on the Uranium Mill Tailings at the Maybell Site, Moffat County, Colorado, UMTRA-SNL/74 4244, November 1982, prepared by FBDU, Salt Lake City, Utah, and Sandia National Laboratories Albuquerque, New Mexico, for the U.S. Department of Energy, UMTRA Project, Albuquerque Operations Office, Albuquerque, New Mexico.

FWS (U.S. Fish and Wildlife Service), 1992. "Interim Survey Requirements for Spiranthes diluvialis," FWS, Salt Lake City, Utah.

FWS (U.S. Fish and Wildlife Service), 1987. "Recovery Implementation Program for Endangered Fish Species in the upper colorado river Basin," Region 6, Denver, Colorado.

Gibbons, R., 1986. County Planner, Moffat County Planning Department, Craig, Colorado, personal communication to Sandra Beranich, Environmental Services Department, Jacobs Engineering Group Inc., Albuquerque, New Mexico, September 23, 1986.

Grahm, V., 1986. Colorado Division of Wildlife, Grand Junction, Colorado, personal communication with Charles J. Burt, Environmental Services Department, Jacobs Engineering Group Inc., Albuquerque, New Mexico, August 29, 1986.

Hettinger, N., 1986. Deputy with Moffat County Sheriff's Department, Craig, Colorado, personal communication to Sandra Beranich, Environmental Services Department, Jacobs Engineering Group Inc., Albuquerque, New Mexico, September 23, 1986.

Hillberry, D., 1986. U.S. Bureau of Land Management, Little Snake Resource Area, Craig, Colorado, personal communication to Dale Jones, Environmental Services Department, Jacobs Engineering Group Inc., Albuquerque, New Mexico, October $22,1986$.

Hoffman, D. M., 1979. "Investigations of the Distribution and Status of Sagebrush and Sage Grouse in the Moffat County Area," Colorado Division of Wildlife, Project No. W-37-R-32, Grand Junction, Colorado.

Husband, J., 1993. Little Snake Resource Area, Bureau of Land Management, Craig, Colorado, personal communication to Woody Woodworth, U.S. Department of Energy, Albuquerque Operations Office, Albuquerque, New Mexico, August 2, 1993. 
ICRP (International Commission on Radiological Protection), 1981. Limits for Intakes of Radionuclides by Workers, ICRP Publication 30, Pergamon Press, Elmsford, New York.

Johnson, B., 1986. Resident Deputy, Moffat County Sheriff's Department, Maybell, Colorado, personal communication to Sandra Beranich, Environmental Services Department, Jacobs Engineering Group Inc., Albuquerque, New Mexico, September 25, 1986.

Kingery, H. E., and W. D. Graul, 1978. "Colorado Bird Distribution Latilong Study," Colorado Division of Wildlife, Denver, Colorado.

Klebenow, D. A., 1969. "Sage Grouse Nesting and Brood Habitat in Idaho," Journal of Wildlife Management, Vol. 33, No. 3, pp. 649-662.

Kropinak, K., 1992. Craig Job Services Center, Colorado Division of Employment and Training, Craig, Colorado, personal communication to Sandra Beranich, Environmental Services Department, Jacobs Engineering Group Inc., Albuquerque, New Mexico, October 9 and 14, 1992.

Kuchler, A. W., 1975. "Potential Natural Vegetation of the Conterminous United States," American Geographic Society Special Publication No. 36, New York, New York (Map).

Lapham et al. (S. C. Lapham, J. B. Millard and J. M. Samet), 1986. "Radionuclide Levels in Cattle Raised Near Uranium Mines and Mills in Northwest New Mexico," New Mexico Environmental Improvement Division, Santa Fe, New Mexico.

May, J., 1992. Sergeant, Moffat County Sheriff's Department, personal communication to Sandra Beranich, Environmental Services Department, Jacobs Engineering Group Inc., Albuquerque New Mexico, October 8, 1992.

McIntyre, S., 1987. Domestic well owner, Maybell, Colorado, personal communication to M. Gilfillan and L. Spencer, United Nuclear Corporation (UNC), under subcontract to Jacobs Engineering Group Inc., Albuquerque, New Mexico, December 11, 1987.

Meyers, L., 1990. Colorado Division of Highways, Denver, Colorado, personal communication to Sandra Beranich, Environmental Services Department, Jacobs Engineering Group Inc., Albuquerque, New Mexico, January 11, 1990.

Millard et al. (J. B. Millard, S. C. Lapham, and P. Hahn), 1986. "Radionuclide Levels In Sheep and Cattle Grazing Near Uranium Mining and Milling at Church Rock, New Mexico," Report EID/RAD 86-3, New Mexico Environmental Improvement Division, Santa Fe, New Mexico. 
Moch, J., 1992. Community Development Secretary, City Hall, Craig, Colorado, personal communication to Sandra Beranich, Environmental Services Department, Jacobs Engineering Group Inc., Albuquerque, New Mexico, September 21, 1992.

Moch, J., 1990. Community Development Secretary, City Hall, Craig, Colorado, personal communication to Sandra Beranich, Environmental Services Department, Jacobs Engineering Group Inc., Albuquerque, New Mexico, February 14, 1990.

MSRD (Mountain States Research and Development), 1982. Economic Evaluation of Inactive Uranium Mill Tailings, Maybell Site, Maybell, Colorado, UMTRADOE/ALO-177, prepared by MSRD, Tucson, Arizona, for the U.S. Department of Energy, UMTRA Project Office, Albuquerque Operations Office, Albuquerque, New Mexico.

NAS/NRC (National Academy of Sciences/National Research Council), 1990. Health Effects of Exposure to Low Levels of lonizing Radiation: BEIR V. National Academy Press, Washington, D.C.

NAS/NRC (National Academy of Sciences/National Research Council), 1988. Health Risks of Radon and other Internally Deposited Alpha-Emitters: BEIR IV, National Academy Press, Washington, D.C.

NOAA (National Oceanic and Atmospheric Administration), 1977. "Climatography of the United States No. 20, Climate of Craig, Colorado," National Climatic Center, Asheville, North Carolina.

Navo, K., 1986. Colorado Division of Wildlife, Maybell, Colorado, personal communication to Charles J. Burt, Environmental Services Department, Jacobs Engineering Group Inc., Albuquerque, New Mexico, September 17, 1986.

ORNL (Oak Ridge National Laboratory), 1980. Radiological Survey of the Inactive Uranium-Mill Tailings at Maybell, Colorado, ORNL-5466, Health and Safety Research Division, Oak Ridge, Tennessee.

Opdycke, J., 1986. "Wetland and Raptor Inventory of the Maybell Site," prepared by the U.S. Fish and Wildlife Service, Grand Junction, Colorado, for the U.S. Department of Energy, UMTRA Project Office, Albuquerque Operations Office, Albuquerque, New Mexico.

Petch, B., 1992. Colorado Division of Wildlife, Maybell, Colorado, personal communication to Charles J. Burt, Environmental Services Department, Jacobs Engineering Group Inc., Albuquerque, New Mexico, October 12, 1992.

Peterson, C., 1986. Colorado Department of Highways, Division of Highways, Denver, Colorado, personal communication to Sandra Beranich, Environmental Services Department, Jacobs Engineering Group Inc., Albuquerque, New Mexico, September 23, 1986. 
Rose, K. L., 1992. United States Department of the Interior, Fish and Wildlife Service, Grand Junction, Colorado, personal communication to James Gibb, Jacobs Engineering Group Inc., Albuquerque, New Mexico, September 21, 1992.

Steele et al. (T. D. Steele, D. P. Bauer, D. A. Wentz, and J. W. Warner), 1979. "The Yampa River Basin, Colorado and Wyoming, A Review of Expanded CoalResource Development and Its Impacts on Regional Water Resources," Water Resource Investigation 78-126, U.S. Geological Survey, Lakewood, Colorado.

TAC (Technical Assistance Contractor), 1992. "Unpublished Field Notes, Maybell, Colorado, Uranium Mill Tailings Site," unpublished report prepared by the Technical Assistance Contractor (Jacobs-Weston Team), Albuquerque, New Mexico, for the U.S. Department of Energy, UMTRA Project Office, Albuquerque Operations Office, Albuquerque, New Mexico.

TAC (Technical Assistance Contractor), 1991. "Maybell Disposal Site Fact Sheet," unpublished report prepared by the Technical Assistance Contractor (JacobsWeston Team), Albuquerque, New Mexico, for the U.S. Department of Energy, UMTRA Project Office, Albuquerque Operations Office, Albuquerque, New Mexico, December 27, 1991.

TAC (Technical Assistance Contractor), 1990. "Unpublished Field Notes, Maybell, Colorado, Uranium Mill Tailings Site," unpublished report prepared by the Technical Assistance Contractor (Jacobs-Weston Team), Albuquerque, New Mexico, for the U.S. Department of Energy, UMTRA Project Office, Albuquerque Operations Office, Albuquerque, New Mexico.

TAC (Technical Assistance Contractor), 1989. "Unpublished Field Notes, Maybell, Colorado, Uranium Mill Tailings Site," unpublished report prepared by the Technical Assistance Contractor (Jacobs-Weston Team), Albuquerque, New Mexico, for the U.S. Department of Energy, UMTRA Project Office, Albuquerque Operations Office, Albuquerque, New Mexico.

TAC (Technical Assistance Contractor), 1987. "Unpublished Field Notes, Maybell, Colorado, Uranium Mill Tailings Site," unpublished report prepared by the Technical Assistance Contractor (Jacobs-Weston Team), Albuquerque, New Mexico, for the U.S. Department of Energy, UMTRA Project Office, Albuquerque Operations Office, Albuquerque, New Mexico.

TAC (Technical Assistance Contractor), 1986a. "Unpublished Field Notes, Maybell, Colorado, Uranium Mill Tailings Site," unpublished report prepared by the Technical Assistance Contractor (Jacobs-Weston Team), Albuquerque, New Mexico, for the U.S. Department of Energy, UMTRA Project Office, Albuquerque Operations Office, Albuquerque, New Mexico. 
TAC (Technical Assistance Contractor), 1986b. "Maybell Groundwater and Surface Water Sampling," unpublished data, prepared by the Technical Assistance Contractor (Jacobs-Weston Team), Albuquerque, New Mexico, for the U.S. Department of Energy, UMTRA Project Office, Albuquerque Operations Office, Albuquerque, New Mexico.

Tar, L., 1990. Administrative Secretary, The Memorial Hospital, Craig, Colorado, personal communication to Sandra Beranich, Environmental Services Department, Jacobs Engineering Group Inc., Albuquerque, New Mexico, February 14, 1990.

Toolen, J., 1992. "Colorado Breeding Bird Atlas Field Card, Atlas Regions A, Map Name Maybell, Map Number 4010851," Grand Junction, Colorado.

Wick et al. (E. J. Wick, J. A. Hawkins, and C. A. Carlson), 1985. "Colorado Squawfish and Humpback Chub Populations and Habitat Monitoring 1983-1984," Colorado Division of Wildlife, Endangered Wildlife Investigations Final Report SE 3-7, Denver, Colorado.

Wildesen, L., 1986. Deputy State Historic Preservation Officer, Colorado Historical Society, Denver, Colorado, personal communication to John Themelis, Project Manager, U.S. Department of Energy, UMTRA Project Office, Albuquerque, New Mexico, August 8, 1986.

\section{CODE OF FEDERAL REGULATIONS}

10 CFR 20, "Standards for Protection Against Radiation," Code of Federal Regulations, Vol. 10, Part 20, U.S. Nuclear Regulatory Commission, Office of the Federal Register, National Archives and Records Administration, Washington, D.C.

40 CFR 143, "National Secondary Drinking Water Regulations," Code of Federal Regulations, Vol. 40, Part 143, U.S. Environmental Protection Agency, Office of the Federal Register, National Archives and Records Administration, Washington, D.C.

40 CFR 192, "Health and Environmental Protection Standards for Uranium and Thorium Mill Tailings," Code of Federal Regulations, Vol. 40, Part 192, U.S. Environmental Protection Agency, Office of the Federal Register, National Archives and Records Administration, Washington, D.C.

40 CFR 264, "Standards for Owners and Operators of Hazardous Waste Treatment, Storage, and Disposal Facilities," Code of Federal Regulations, Vol. 40, Part 264, U.S. Environmental Protection Agency, Office of the Federal Register, National Archives and Records Administration, Washington, D.C. 


\section{FEDERAL REGISTER}

52 FR 36000, "Standards for Remedial Actions at Inactive Uranium Processing Sites; Proposed Rule," September 24, 1987, Federal Register.

\section{PUBLIC LAWS}

PL 95-604 (Public Law 95-604), 1978. Uranium Mill Tailings Radiation Control Act of 1978, 42 USC 7901, November 8, 1978, 95th Congress of the United States of America, Washington, D.C. 
ATTACHMENT 1

BIOLOGICAL ASSESSMENT 


\section{TABLE OF CONTENTS}

Section

Page

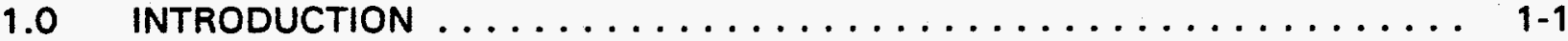

2.0 DESCRIPTIONS OF THE PROPOSED ACTION AND STUDY AREA $\ldots \ldots$

2.1 Proposed action ........................ 2-1

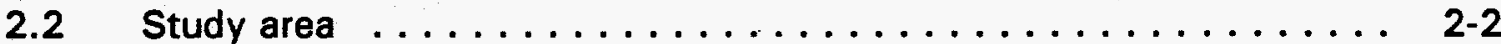

2.2.1 Maybell tailings site plant communities .......... 2-2

2.2.2 Maybell site fauna .................... 2-11

2.3 Proposed borrow sites ..................... 2-12

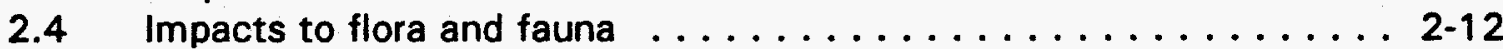

3.0 THREATENED AND ENDANGERED SPECIES $\ldots \ldots \ldots \ldots \ldots \ldots \ldots \ldots$

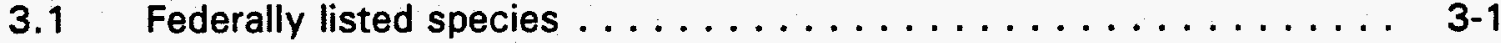

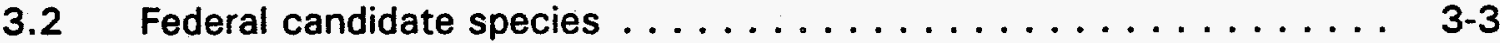

3.3 Summary ........................ 3-6

$4.0 \quad$ REFERENCES $\ldots \ldots \ldots \ldots \ldots \ldots \ldots \ldots \ldots \ldots \ldots \ldots \ldots \ldots \ldots \ldots$ 


\section{LIST OF FIGURES}

\section{Figure}

1.1 Location map of the Maybell tailings site near Maybell, Colorado . . . . . . 1-2

2.1 Wetland plant community types in the contaminated section of Johnson Wash and Lay Creek at the Maybell site near Maybell, Colorado . . . . . . . 2-10

\section{LIST OF TABLES}

\section{Table}

$2.1 \quad$ Plant species observed in the area of the Maybell site . . . . . . . . . . . . .

2.2 Amphibians and reptiles observed or expected to occur in the area of the

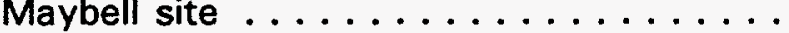

2.3 Bird species observed at or near the Maybell site . . . . . . . . . . . . 2-6

2.4 Mammals observed or expected to occur in the area of the Maybell site . . . 2-8 


\section{LIST OF ACRONYMS AND ABBREVIATIONS}

\begin{tabular}{|c|c|}
\hline Acronym & Definition \\
\hline$a c$ & acres \\
\hline $\mathrm{ac}-\mathrm{ft}$ & acre-feet \\
\hline BLM & $\begin{array}{l}\text { Bureau of Land Management } \\
\text { centimeters }\end{array}$ \\
\hline COE & United States Corps of Engineers \\
\hline $\begin{array}{l}\text { DOE } \\
\mathrm{ft}\end{array}$ & $\begin{array}{l}\text { U.S. Department of Energy } \\
\text { feet }\end{array}$ \\
\hline $\begin{array}{l}\text { FWS } \\
\text { ha }\end{array}$ & $\begin{array}{l}\text { U.S. Fish and Wildlife Service } \\
\text { hectares }\end{array}$ \\
\hline in & inches \\
\hline $\mathrm{km}$ & kilometers \\
\hline $\mathrm{km}^{2}$ & square kilometers \\
\hline$m_{3}$ & meters \\
\hline $\mathrm{m}^{3}$ & cubic meters \\
\hline $\begin{array}{l}\mathrm{mi}^{2} \\
\mathrm{mi}^{2}\end{array}$ & miles \\
\hline $\mathrm{PL}$ & Public Law \\
\hline
\end{tabular}




\subsection{INTRODUCTION}

Pursuant to the Uranium Mill Tailings Radiation Control Act of 1978, Public Law (PL) 95-604, the U.S. Department of Energy (DOE) is conducting a remedial action program designed to clean up the residual radioactive materials at a site near Maybell, Colorado (Figure 1.1). An important part of the environmental assessment of the remedial action is the consideration of threatened and endangered flora and fauna that may be affected by the project. This biological assessment includes communications with the U.S. Fish and Wildlife Service (FWS) to ascertain their concerns regarding threatened and endangered species. In February 1986, the FWS provided a list of species that may occur near the Maybell site. This list was updated in December 1988, April 1990, and September 1992 (Appendix 1). This assessment addresses the species listed in the September 1992 letter and includes descriptions of the proposed action, the ecological setting, the historical and current status of the species of concern, and a finding as to whether the remedial action would impact the species. 


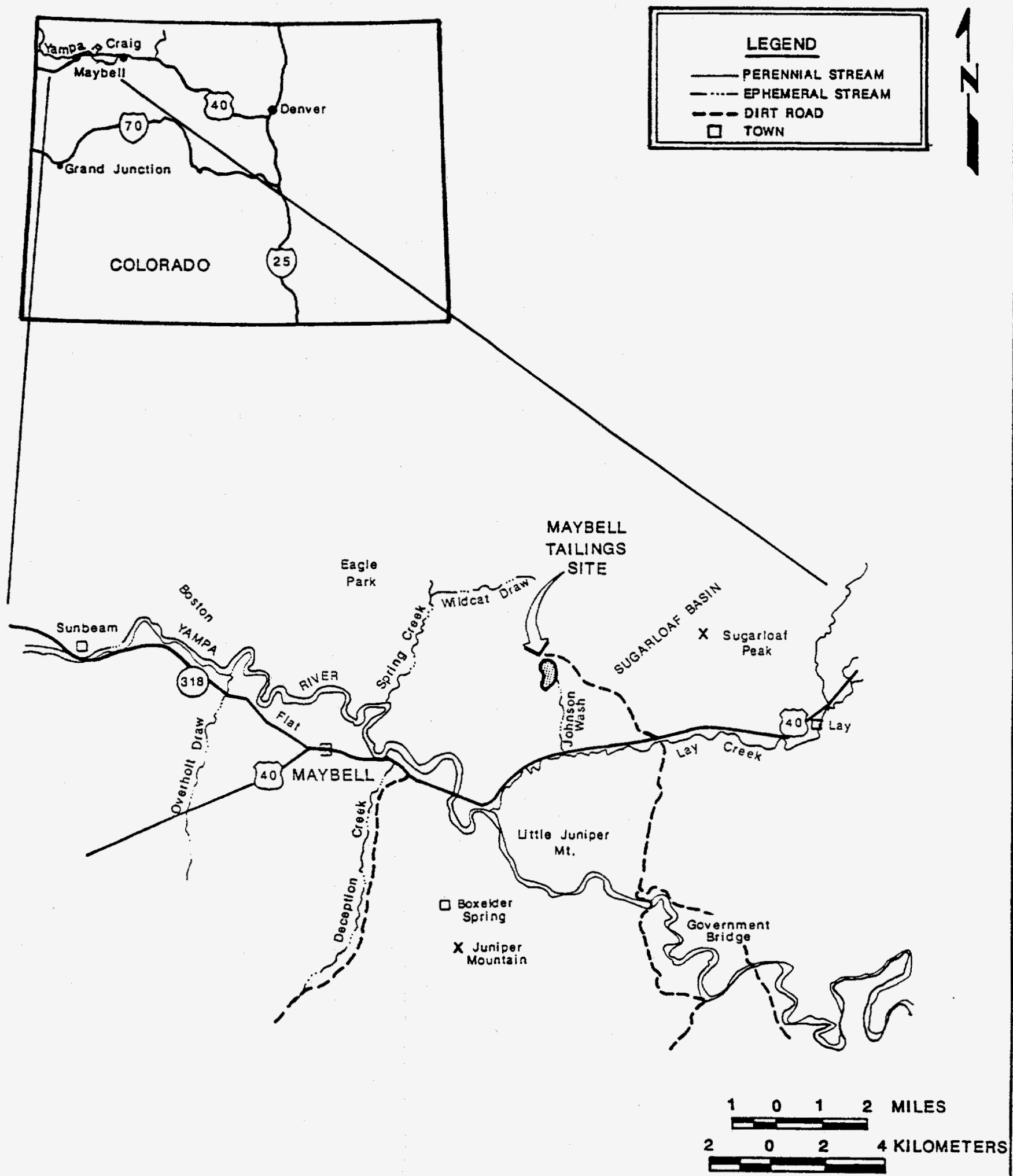

FIGURE 1.1

LOCATION MAP OF THE MAYBELL TAILINGS SITE NEAR MAYBELL, COLORADO 


\subsection{DESCRIPTIONS OF THE PROPOSED ACTION AND STUDY AREA}

\subsection{PROPOSED ACTION}

The proposed action is to stabilize in place the residual radioactive materials at the existing Maybell tailings site. The materials to be stabilized in an aboveground disposal cell are contaminated with low levels of radioactive constituents. Contaminated areas at the Maybell site include the tailings pile and mill yard areas, windblown areas adjacent to the tailings pile, and waterborne contaminated areas along Johnson Wash and Lay Creek. The contaminated materials would be covered with a multi-component cover on the top and sides to inhibit radon emanation from the contaminated materials and water infiltration through the disposal cell. The total estimated volume of contaminated materials to be disposed at the site is approximately 3.5 million cubic yards $\left(2.7\right.$ million cubic meters $\left[\mathrm{m}^{3} \mathrm{~J}\right)$.

Three off-site locations are proposed as sources of borrow materials. Gravel would be obtained from the Maybell gravel source located along the Yampa River 1 mile (mi) (1.6 kilometer [km]) northeast of Maybell, Colorado, and $4.5 \mathrm{mi}$ $(7.2 \mathrm{~km})$ west of the site. Large rock would be obtained from two sources; the Juniper Mountain Limestone Quarry lalso known as the Don Steele Limestone Quarry) and the Craig Basalt Quarry (also known as the Don Steele Basalt Quarry). The Juniper Mountain Limestone Quarry is an existing quarry operation and is 2.5 road mi $(4 \mathrm{~km})$ south of U.S. Highway 40 and about 7.2 road mi $(11.6 \mathrm{~km})$ from the tailings site. The Craig Basalt Quarry is approximately 9 road mi $(14.5 \mathrm{~km})$ southeast of Craig, Colorado and approximately 30 road mi $(48 \mathrm{~km})$ from the tailings pile.

Implementation of the proposed action would result in the disturbance of approximately 270 acres (ac) (110 hectares [ha]) of land. Disturbed areas include the disposal site and associated windblown and waterborne contaminated areas, the Rob Pit overburden pile borrow site, and the three offsite borrow sites. However, past mining and processing activities have previously disturbed much of the land at and surrounding the tailings pile. In addition, the three off-site locations proposed as sources of borrow material are existing operations and have been previously disturbed.

Remedial action is anticipated to take approximately 19 months to complete; which includes a 5-month winter shutdown period. The final restricted area would cover approximately 165 ac (67 ha). The perimeter of the area would be marked with warning signs, boundary markers, and survey monuments. The areas surrounding the disposal cell that were disturbed by the remedial action would be backfilled as required, graded to control surface drainage, and revegetated. 


\subsection{STUDY AREA}

The Maybell tailings site is in sagebrush-steppe habitat within the Wyoming Basin (Kuchler, 1975). The Wyoming Basin is a large area mostly in Wyoming with relatively small areas in Colorado, Idaho, and Utah.

Information regarding the flora and fauna at the Maybell site was derived from field reconnaissance surveys by the Technical Assistance Contractor (TAC, 1992, 1990, 1987, 1986; DOE, 1983), consultations with natural resource personnel from state and federal agencies, and review of the pertinent literature. Lists of the flora and fauna observed or expected to occur at the site plus scientific names of most species referred to in the text appear in Tables 2.1 through 2.4. These tables do not represent a complete listing of species in this area. Rather, they are species observed at the site during the reconnaissance surveys or species recorded in the area from other sources. The plant species list (Table 2.1) was derived from site-specific surveys (TAC, 1986; DOE, 1983). The amphibian and reptile (Table 2.2) and mammal (Table 2.4) lists were generated from limited site surveys plus other information as referenced in the tables. The bird species table (Table 2.3) lists nesting birds and a few migratory species that were observed at and near the site.

\subsubsection{Maybell tailings site plant communities}

The Maybell tailings site includes the tailings pile, mill site area, the Rob Pit overburden pile borrow site, the windblown contaminated area, and waterborne contaminated areas along Johnson Wash and Lay Creek.

Plant species observed in the area of the Maybell site are presented in Table 2.1. Three plant community types have been identified at the site. The first type included grass/herb dominated areas that occur at disturbed sites such as the tailings pile, the Rob Pit overburden pile, and other surrounding disturbed areas. The tailings pile is covered with a thin layer of topsoil and has been revegetated with crested wheatgrass (DOE, 1983). Other plant species indicative of disturbed sites grow on the tailings pile, including cheatgrass, foxtail barley, Russian thistle, yellow sweet clover, and tumble mustard. Occasional big sagebrush and rabbitbrush shrubs occur on the pile. Yellow sweet clover is the most common plant species on the Rob Pit overburden pile; other early successional species as listed above are also present.

A sagebrush-dominated plant community occurs in the windblown contaminated area around the tailings pile. This second plant community type is the most common in the region, comprising almost 57 percent of the vegetative cover within the Bureau of Land Management's (BLM) Little Snake River Resource Area (BLM, 1986). Big sagebrush is the most common shrub species. Other species of shrubs include rabbitbrush, fringed sagebrush, broom snakeweed, and some antelope bitter-brush. Crested wheatgrass and other species of grass are also common. This plant community also occurred in and along Johnson Wash and next to Lay Creek. Black greasewood is common in the sagebrush 
Table 2.1 Plant species observed in the area of the Maybell site

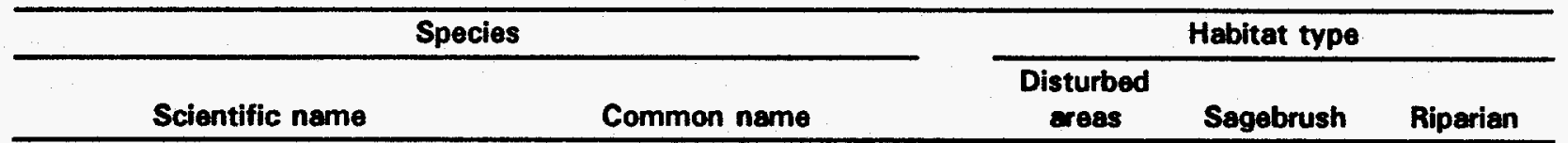

Artemisia frigida

Artemisia tridentata

Chrysothamnus nauseosus

Chrysothamnus viscidiflorus

Eurotia lanata

Opuntia sp.

Populus angustifolia

Populus fremontii

Purshia tridentata

Salix sp.

Sarcobatus vermiculatus

Xanthocephalum sarothrae

Achillea millefolium

Allium acuminatum

Astragalus sp.

Brassica sp.

Calochortus sp.

Castilleja sp.

Chaenactis douglasii

Chenopodium sp.

Cirsium arvense

Cirsium vulgare

Cleome serrulata

Comandra pallida

Cryptantha cinerea

Cryptantha fendieri

Erigeron engelmannii

Eriogonum microthecum

Eriogonum ovalifolium

Grindelia squarrosa

Halogeton glomeratus

Haplopappus sp.

Heterotheca villosa

Lepidium perfoliatum

Leptodactylon pungens

Lupinus sericeus

Machaeranthera canescens
TREES AND SHRUBS

fringed sagebrush

big sagebrush

rubber rabbitbrush

Douglas rabbitbrush

common winter fat

prickly pear cactus

narrow-leaf cottonwood

Fremont cottonwood

antelope bitter-brush

Willow

black greasewood

broom snakeweed

$\begin{array}{lll}x & x & \\ x & x & x \\ x & x & x \\ & x & x \\ & x & \\ & & x \\ & x \\ & x \\ & x \\ & \\ & \end{array}$

FORBS AND HERBS

yarrow

wild onion

milkvetch

mustard

mariposa lily

paintbrush

Douglas chaenactis

goosefoot

$x$

Canada thistle

Rocky Mountain bee plant

bastard toadflax

catseye

catseye

Engelmann fleabane

slenderbush buckwheat

cushion buckwheat

gumweed

halogeton

goldenweed

hairy golden aster

clasping pepperweed

prickly gilia

$x \quad x$

silky lupine

hoary aster $x$

$x$

$x$

$\begin{array}{cc} & x \\ x & x \\ & x \\ x & \\ x & x \\ x & x \\ & x \\ & x \\ & x\end{array}$

$x$

\section{$x$ \\ $x$}

$x$

x

$x$

$x$

$x$

$x$

$x$

$x$

$x$

$x$
$x$

$x$

$x$

$x$

$x$

$x$

$x$

$x$

$x$

$x$

$x$

$x$

$x$

$x$

$x$ 
Table 2.1 Plant species observed in the area of the Maybell site (Concluded)

\begin{tabular}{|c|c|c|c|c|}
\hline \multicolumn{2}{|c|}{ Species } & \multicolumn{3}{|c|}{ Habitat type } \\
\hline Scientific name & Common name & $\begin{array}{c}\text { Disturbed } \\
\text { areas }\end{array}$ & Sagebrush & Riperian \\
\hline \multicolumn{5}{|c|}{ FORBS AND HERBS (Continued) } \\
\hline Melilotus albus & white sweet clover & $\mathrm{x}$ & $x$ & $x$ \\
\hline Melilotus officinalis & yellow sweet clover & $x$ & $x$ & $x$ \\
\hline Oenothera trichocalyx & evening primrose & & $x$ & \\
\hline Orobanche ludoviciana & broomrape & & $\mathbf{x}$ & \\
\hline Penstemon caespitosus & mat penstemon & & $x$ & \\
\hline Penstemon fremontii & Fremont penstemon & & $x$ & \\
\hline Phlox hoodii & Hoods phlox & & $x$ & \\
\hline Phlox longifolia & longleaf phlox & & $x$ & \\
\hline Polygonum douglasii & Douglas knotweed & & $x$ & \\
\hline Psoralea lanceolata & lemon scurfpea & & $x$ & \\
\hline Sagittaria sp. & arrowhead & & & $x$ \\
\hline Salsola kali & Russian thistle & $x$ & $\mathbf{x}$ & \\
\hline Sisymbrium altissimum & tumble mustard & $x$ & $\mathrm{x}$ & $x$ \\
\hline Solanum triflorum & cutleaf nightshade & $x$ & $\mathrm{x}$ & \\
\hline Sphaeraicea coccinea & scarlet globemallow & $x$ & $x$ & $\mathrm{x}$ \\
\hline Taraxacum officinale & common dandelion & & & $x$ \\
\hline Tragopogon dubius & yellow salsify & & & $x$ \\
\hline Typha sp. & cattail & & & $x$ \\
\hline Verbascum thapsus & flannel mullein & & & $x$ \\
\hline \multicolumn{5}{|c|}{ GRASS AND GRASSLIKE SPECIES } \\
\hline Agropyron cristatum & crested wheatgrass & $x$ & $\mathrm{x}$ & \\
\hline Agropyron smithii & western wheatgrass & $x$ & $\mathrm{x}$ & \\
\hline Agropyron spicatum & bluebunch wheatgrass & $x$ & $x$ & \\
\hline Bromus tectorum & cheatgrass & $x$ & & $x$ \\
\hline Carex sp. & sedge & & & $\mathbf{x}$ \\
\hline Eleocharis sp. & spike-rush & & & $x$ \\
\hline Festuca ovina & sheep fescue & & $\mathrm{x}$ & \\
\hline Hilaria jamesii & galleta & & $x$ & \\
\hline Hordeum jubatum & foxtail barley & $x$ & $x$ & $\mathbf{x}$ \\
\hline Juncus balticus & baltic rush & & & $x$ \\
\hline Juncus sp. & rush & & & $x$ \\
\hline Koeleria cristata & prairie junegrass & & $x$ & \\
\hline Oryzopsis hymenoides & Indian ricegrass & & $x$ & \\
\hline Poa sandbergii & Sandberg bluegrass & & $x$ & \\
\hline Scirpus validus & softstem bulrush & & & $x$ \\
\hline Sitanion hystrix & squirrel tail & & $x$ & \\
\hline Stipa comata & needle and thread & & $\mathrm{x}$ & \\
\hline
\end{tabular}

References: TAC, 1986; DOE, 1983; BOR, 1981. 
Table 2.2 Amphibians and reptiles observed or expected to occur in the area of the Maybell site

\begin{tabular}{|c|c|c|c|c|}
\hline \multicolumn{2}{|c|}{ Species } & \multicolumn{3}{|c|}{ Habitat typo } \\
\hline Scientific name & Common name & $\begin{array}{l}\text { Disturbed } \\
\text { areas }\end{array}$ & Sagebrush & Riparian \\
\hline Ambystoma tigrinum & tiger salamander & & $x$ & $x$ \\
\hline Rana catesbeiana & bullfrog & & & $x$ \\
\hline Rana pipiens ${ }^{a}$ & leopard frog & & & $x$ \\
\hline Scaphiopus intermontanus & $\begin{array}{l}\text { Great Basin spadefoot } \\
\text { toad }\end{array}$ & & $x$ & $x$ \\
\hline Bufo woodhousei & Woodhouse's toad & & $x$ & $x$ \\
\hline Chrysemys picta & painted turtle & & & $x$ \\
\hline Crotaphytus collaris & collared lizard & $x$ & $x$ & $x$ \\
\hline Sceloporus undulatus & eastern fence lizard & $x$ & $x$ & \\
\hline Sceloporus graciosus ${ }^{a}$ & sagebrush lizard & & $x$ & $x$ \\
\hline Uta stansburiana & side-blotched lizard & $x$ & $x$ & $x$ \\
\hline Phrynosoma douglassi & short-horned lizard & $x$ & $x$ & $x$ \\
\hline Coluber constrictor ${ }^{a}$ & Racer & & & $x$ \\
\hline Pituophis melanoleucus & gopher snake & $x$ & $x$ & $x$ \\
\hline Thamnophis elegans & $\begin{array}{l}\text { western terrestrial } \\
\text { garter snake }\end{array}$ & & & $x$ \\
\hline Crotalus viridis $^{\mathbf{a}}$ & western rattlesnake & & $x$ & $x$ \\
\hline
\end{tabular}

Species observed at or near the site.

References: TAC, 1992, 1987, 1986; DOE, 1983; Bernard and Brown, 1978. 
Table 2.3 Bird species observed at or near the Maybell site

\begin{tabular}{|c|c|c|c|c|c|}
\hline \multicolumn{2}{|c|}{ Species } & \multicolumn{4}{|c|}{ Nesting habitat type } \\
\hline Scientific name & Common name & Disturbed areas & Sagebrush & Riparian & Other \\
\hline Phalacrocorax auritus ${ }^{a}$ & double-crested cormorant & & & & $x^{b}$ \\
\hline Ardea herodias ${ }^{c}$ & great blue heron & & & $x$ & \\
\hline Grus canadensis d & sandhill crane & & & & \\
\hline Brenta canadenis ${ }^{c}$ & Canada goose & & & & $x^{b}$ \\
\hline Anas platyrhynchos ${ }^{c}$ & mallard & & & $x$ & \\
\hline Anas creccac & green-winged teal & & & $x$ & \\
\hline Anas acuta ${ }^{a, c}$ & northern pintail & & & $x$ & \\
\hline Anas strepera ${ }^{a, c}$ & gadwall & & & $x$ & \\
\hline Anas clypeata ${ }^{c}$ & northern shoveler & & & $x$ & \\
\hline Anas cyanoptera ${ }^{c}$ & cinnamon teal & & & $x$ & \\
\hline Mergus merganser ${ }^{c}$ & common merganser & & & & $x^{b}$ \\
\hline Charadrius vociferus $^{c}$ & killdeer & $x$ & & & \\
\hline Capella gallinago & common snipe & & & $x$ & \\
\hline Bartramia longicauda" & upland sandpiper & & & $x$ & \\
\hline Tringa melanoleuca ${ }^{d}$ & greater yellowlegs & & & $x$ & \\
\hline Actitis macularia $^{c}$ & spotted sandpiper & & & $x$ & \\
\hline Phalaropus tricolor ${ }^{c}$ & Wilson's phalarope & & & $x$ & \\
\hline Cathartes aura ${ }^{c}$ & turkey vulture & & & & $x^{\bullet}$ \\
\hline Aquila chrysaetos ${ }^{c}$ & golden eagle & & & & $x^{0}$ \\
\hline Buteo jamaicensis $^{c}$ & red-tailed hawk & & $x$ & & \\
\hline Falco sparverius ${ }^{c}$ & American kestrel & & $x$ & & \\
\hline Centrocercus urophasianus ${ }^{c}$ & sage grouse & & $x$ & $x$ & \\
\hline Zenaida macroura ${ }^{c}$ & mourning dove & & $x$ & $x$ & \\
\hline Chordeiles minor ${ }^{c}$ & common nighthawk & & $x$ & $x$ & \\
\hline Coloptes auratus ${ }^{c}$ & common flicker & & & $x$ & \\
\hline Tyrannus verticalis $^{c}$ & western kingbird & & & $x$ & \\
\hline Contopus sordidulus ${ }^{c}$ & western wood-pewee & & & $x$ & \\
\hline Myiarchus cinerascens ${ }^{\circ}$ & ash-throated flycatcher & & & $x$ & \\
\hline Sayornis saya & Say's phoebe & & $x$ & & \\
\hline Empidonax wrightif & gray flycatcher & & $x$ & & \\
\hline Eremophila alpestris ${ }^{c}$ & horned lark & $\mathbf{x}$ & & & \\
\hline Hirundo pyrrhonotac & cliff swallow & & & $\mathrm{x}$ & \\
\hline Hirundo rustica ${ }^{c}$ & barn swallow & & & $x$ & \\
\hline Stelgidopteryx ruficollis & rough-winged swellow & & & & $x^{b}$ \\
\hline Riparia riparia ${ }^{a}$ & bank swallow & & & $x$ & \\
\hline Tachycineta thalassina & violet-green swallow & & & $x$ & \\
\hline Pica pica ${ }^{c}$ & black-billed magpie & & $x$ & $x$ & \\
\hline Corvus corax ${ }^{c}$ & common raven & & & & $x^{0}$ \\
\hline Gymnorhinus cyanocepha/us ${ }^{d}$ & pinyon jay & & $x$ & & \\
\hline Parus atricapillus ${ }^{\mathbf{c}}$ & black-capped chickadee & & $x$ & & \\
\hline Parus inornatus ${ }^{c}$ & plain titmouse & & $x$ & & \\
\hline Salpinctes obsoletus ${ }^{c}$ & rock wren & & $x$ & $x$ & \\
\hline
\end{tabular}


ATTACHMENT 1

Table 2.3 Bird species observed at or near the Maybell site (Concluded)

\begin{tabular}{|c|c|c|c|c|c|}
\hline \multicolumn{2}{|c|}{ Species } & \multicolumn{4}{|c|}{ Nesting habitat type } \\
\hline Scientific name & Common name & Disturbed areas & Sagebrush & Riparian & Other \\
\hline Sialia currucoides ${ }^{c}$ & mountain bluebird & & $x$ & $x$ & \\
\hline Turdus migratorius ${ }^{c}$ & robin & & & $x$ & \\
\hline Lanius ludovicianus & loggerhead shrike & & $x$ & $\mathbf{x}$ & \\
\hline Mimus polyglottos ${ }^{c}$ & northern mockingbird & & $x$ & $x$ & \\
\hline Oreoscoptes montanus ${ }^{c}$ & sage thrasher & & $\mathbf{x}$ & $\mathbf{x}$ & \\
\hline Vireo gilvus ${ }^{c}$ & warbling vireo & & & $x$ & \\
\hline Dendroica petechia ${ }^{c}$ & yollow warbler & & & $x$ & \\
\hline Dendroica nigrescens ${ }^{c}$ & black-throated gray warbler & & $x$ & & \\
\hline Icteria virens ${ }^{c}$ & yellow-breasted chat & & & $x$ & \\
\hline Guiraca caerulea $^{c}$ & blue grosbeak & & & $x$ & \\
\hline Pipilo chlorurus ${ }^{c}$ & green-tailed towhee & & $x$ & $x$ & \\
\hline Zonotrichia leucophrys ${ }^{d}$ & white-crowned sparrow & & $x$ & $x$ & \\
\hline Spizella breweric & Brewer's sparrow & & $x$ & & \\
\hline Pooecetes gramineus ${ }^{c}$ & vesper sparrow & & $x$ & & \\
\hline Amphispiza bellic & sage sparrow & & $x$ & & \\
\hline Melospiza melodia & song sparrow & & & $x$ & \\
\hline Spizella passerinac & chipping sparrow & & $x$ & & \\
\hline Junco hyermalis ${ }^{d}$ & dark-eyed junco & & & & \\
\hline Sturnella neglecta ${ }^{c}$ & western meadowlark & $x$ & $x$ & $x$ & \\
\hline Quiscalus quisculad & common grackle & & & $x$ & \\
\hline Euphagus cyanocephalus & Brewer's blackbird & & & $x$ & \\
\hline Agelaius phoeniceus ${ }^{c}$ & red-winged blackbird & & & $x$ & \\
\hline Xenthocephalus xanthocephalus ${ }^{c}$ & yellow-headed blackbird & & & $\mathbf{x}$ & \\
\hline Molothrus ater ${ }^{\mathrm{C}}$ & brown-headed cowbird & & $x$ & $x$ & \\
\hline lcterus galbulac & northern oriole & & & $x$ & \\
\hline Carpodacus mexicanus ${ }^{c}$ & house finch & & $x$ & $x$ & \\
\hline Carduelis tristis ${ }^{c}$ & American goldfinch & & & $x$ & \\
\hline
\end{tabular}

"Not observed during site reconnaissance surveys; recorded by Grahm (1986) and Toolen (1992) from the area.

${ }^{b}$ Nests only along the Yampa River.

Nesting species observed at the Maybell site area.

'Migrant species observed at the Maybell site.

Typically nests in cliff habitat.

References: TAC, 1992, 1990, 1987, 1986; Grahm, 1986; DOE, 1983; Toolen, 1992. 
ATTACHMENT 1

Table 2.4 Mammals observed or expected to occur in the area of the Maybell site

\begin{tabular}{|c|c|c|c|c|}
\hline \multicolumn{2}{|c|}{ Species } & \multicolumn{3}{|c|}{ Habitat Type } \\
\hline Scientific name & Common name & Disturbed areas & Sagebrush & Riparian \\
\hline Didelphis virginiena & opossum & & & $x$ \\
\hline Sorex merriami & Merriam's shrew & & $x$ & $x$ \\
\hline Myotis yumenensis & Yuma myotis & & & $x$ \\
\hline Myotis californicus & California myotis & $\mathbf{x}$ & $x$ & $x$ \\
\hline Plocotus townsendii & Townsend's big-eared bat & $x$ & $x$ & $x$ \\
\hline Antrozous pallidus & pallid bat & $x$ & $x$ & $x$ \\
\hline Sylvilagus audubonii & desert cottontail & $x$ & $x$ & $x$ \\
\hline Lepus californicus & black-tailed jackrabbit & $\mathbf{x}$ & $x$ & $x$ \\
\hline Eutamias minimus ${ }^{\circ}$ & loast chipmunk & & $x$ & $x$ \\
\hline Spermophilus richardsonil & Richardson's ground squirrel & $x$ & $x$ & $x$ \\
\hline Thomomys talpoides & northern pocket gopher & $x$ & $x$ & $x$ \\
\hline Dipodamys ordii & Ord's kangaroo rat & $x$ & $x$ & $x$ \\
\hline Reithrodontomys megalotis & western harvest mouse & $\mathbf{x}$ & $x$ & $x$ \\
\hline Peromyscus maniculatus & deer mouse & $\mathbf{x}$ & $x$ & $x$ \\
\hline Peromyscus truei & pinon mouse & & $x$ & $x$ \\
\hline Onychomys loucogaster & northern grasshopper mouse & $x$ & $x$ & \\
\hline Neotome cinerea & bushy tailed woodrat & & $x$ & $x$ \\
\hline Microtus longicaudus & long-tailed vole & & & $x$ \\
\hline Lagurus curtatus & sagebrush vole & & $x$ & $x$ \\
\hline Ondatra zibethicus ${ }^{\circ}$ & muskrat & & & $x$ \\
\hline Erethizon dorsatum ${ }^{a}$ & porcupine & & $x$ & $x$ \\
\hline Canis latrans ${ }^{\circ}$ & coyote & $x$ & $x$ & $x$ \\
\hline Urocyon cinereoargenteus & gray fox & & $x$ & $x$ \\
\hline Procyon lotor & raccoon & & $x$ & $x$ \\
\hline Mustela frenata & long-tailed weasel & $x$ & $x$ & $x$ \\
\hline Mustela vison & mink & & & $x$ \\
\hline Taxidea taxus & badger & $x$ & $x$ & $x$ \\
\hline Spilogale gracilis & western spotted skunk & $\mathbf{x}$ & $x$ & $x$ \\
\hline Mephitis mephitis & striped skunk & & & $x$ \\
\hline Felis rufus & bobcat & $x$ & $x$ & $x$ \\
\hline Cervus olaphusa & elk & & $x$ & $x$ \\
\hline Odocoileus hemionus & mule deer & $x$ & $x$ & $x$ \\
\hline Antilocapra americana" & pronghorn antelope & $x$ & $x$ & $x$ \\
\hline
\end{tabular}

aspecies or sign observed on or near the site.

References: TAC, 1987, 1986; DOE, 1983; Bernard and Brown, 1978. 
habitat along Lay Creek. A total of 54 species of plants were observed in this plant community type (Table 2.1).

Riparian habitat is the third plant community type; it occurs along Johnson Wash and Lay Creek. This community is relatively uncommon in the Little Snake River Resource Area, accounting for only 0.2 percent of the vegetative cover (BLM, 1986). The riparian plant communities occur in three distinct types. The first type occurs along Johnson Wash where the channel widens, approximately 3000 feet (ft) (900 meters [m]) downstream of the tailings pile. Species typical of disturbed conditions are common in this area and include yellow sweet clover, tumble mustard, Rocky Mountain bee plant, mustard, yarrow, Canada thistle, bull thistle, and yellow salsify. In addition, such species as baltic rush and sedge also occur. Grass species, particularly foxtail barley, are also common. Observations during the summer and spring (July 1986 and May 1989) indicated that the ground was moist within some of the area (TAC, 1986; 1989), while in the fall (September 1992) the area was dry (TAC, 1992).

The second riparian plant community type starts in Johnson Wash about $\mathbf{3 5 0 0}$ $\mathrm{ft}(1100 \mathrm{~m})$ downstream (south) from the tailings pile and continues almost to the confluence of Johnson Wash and Lay Creek. In this area, there is increased soil moisture and the growth of early successional plants gives way to a dominance of more wetland species such as baltic rush and sedge. Foxtail barley is a common species and white clover forms dense patches in some areas. Two springs form surface flows in Johnson Wash within this riparian plant community.

The third type of riparian plant community occurs along Lay Creek. Lay Creek is spring fed and holds water all year. Typically, water flow in the creek is 4 to 12 $\mathrm{ft}(1.2$ to $3.7 \mathrm{~m})$ wide, and 6 to 12 inches (in) (15 to 30 centimeters [cm]) deep. The creek is bordered by a dense stand of baltic rush which is 2 to $4 \mathrm{ft}$ $(0.6$ to $1.2 \mathrm{~m})$ high. Other common wetland plant species observed in this community include softstem bulrush, rabbitfoot grass, cattail, arrowhead, and inland saltgrass. During periods when the only water in Lay Creek is from springs, there are relatively long stretches of standing water interspersed with stretches of dry creek bed (TAC, 1986; 1992).

The wetland habitat along Johnson Wash and Lay Creek was mapped by the FWS (Opdycke, 1986) (Figure 2.1). Using the Cowardin et al. (1979) wetland classification system, the FWS determined that there were approximately 9 ac (4 ha) of wetlands along Johnson Wash, which were comprised of palustrine emergent/temporarily flooded ( 7 ac [ 3 ha]), riverine intermittent streambed/temporarily flooded (2 ac [1.0 ha]), and palustrine unconsolidated bottom/semipermanently flooded (0.2 ac $[0.08$ hal) types. A total of 22 ac (9 ha) of wetlands were mapped along Lay Creek, comprising 8 ac ( 3 ha) of palustrine emergent/temporarily flooded and $14 \mathrm{ac}$ ( $6 \mathrm{ha}$ ) of riverine intermittent streambed/temporarily flooded types. Field surveys by the U.S. Army Corps of Engineers (COE) in 1989 and 1992 determined that the wetlands mapped by the FWS are also COE-regulated wetlands (Davis, 1989; Mezei, 1992). 


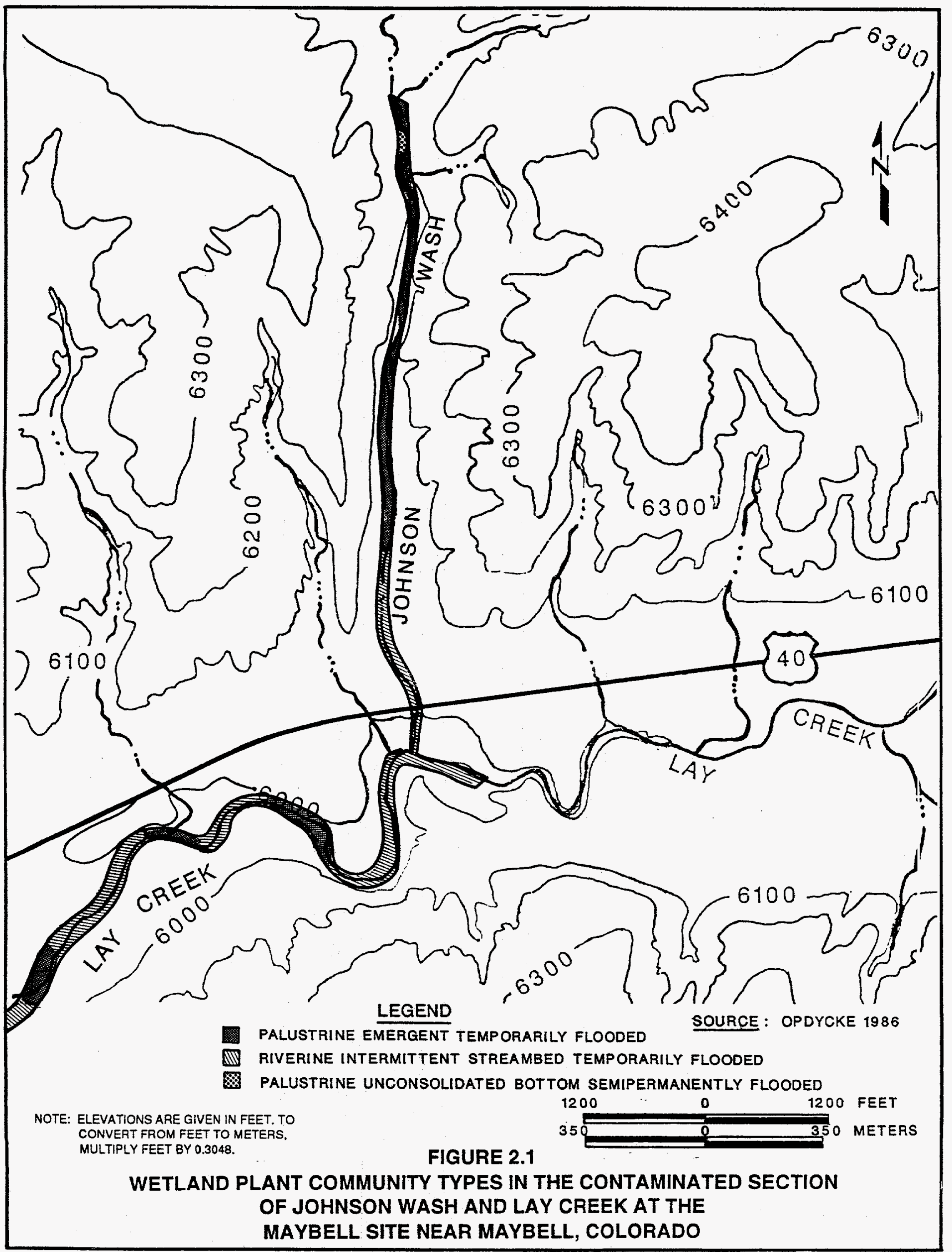




\subsubsection{Maybell site fauna}

A total of 15 species of amphibians and reptiles may occur at the Maybell tailings site and proposed borrow sites (Table 2.2). The only species observed on the site were the leopard frog and racer along Lay Creek and the western rattlesnake and sagebrush lizard along Johnson Wash. The largest number of species would be expected to occur in the riparian habitat (14) followed by the sagebrush habitat (10).

A total of 69 bird species have been observed at or near the Maybell tailings and borrow sites (Table 2.3). This total represents common nesting species and a few solely migratory species. A few nesting species plus additional migrating and wintering species could be expected at the site. The largest number of species were observed in the riparian habitat (46), followed by the sagebrush habitat (26).

Three waterfowl broods were observed along a 6500-ft $(2000-\mathrm{m})$ section of Lay Creek in July 1986 (TAC, 1986). Two broods were green-winged teal; the third was a northern shoveler brood comprised of six half-grown young. Other species of waterfowl that may be expected to nest along Lay Creek are the mallard, gadwall, cinnamon teal, and northern pintail (Grahm, 1986). Two common merganser broods, one Canada goose brood, and one mallard brood were observed along the Yampa River in the area of the Maybell gravel source borrow site in 1990 (TAC, 1990).

Birds of prey observed at or near the site were the golden eagle, red-tailed hawk, and American kestrel. Golden eagles were observed near Lay Creek and on the steep cliff habitat of Rob Pit just west of the tailings pile. Aerial surveys of the site, including a $2-\mathrm{mi}(3.2-\mathrm{km})$ buffer zone, indicated that golden eagles had an active nest approximately $0.5 \mathrm{mi}(0.8 \mathrm{~km})$ west of the tailings site and another active nest approximately $2 \mathrm{mi}(3.2 \mathrm{~km})$ east of the confluence of Johnson Wash and Lay Creek (Opdycke, 1986). The adults were tending the nests but produced no young; a drastically reduced prey base is the probable reason (Lockhart, 1986a).

A total of 33 species of mammals were observed or may occur in the area of the Maybell site (Table 2.4). The largest number of species occur in the riparian habitat (32), followed by the sagebrush habitat (27). Detailed mammal studies were not conducted at the Maybell site and only a few species (10) were observed during the reconnaissance surveys. Muskrat signs were observed along Lay Creek and coyotes were heard and observed in three areas.

The sage grouse is the principal game bird at the Maybell site. The major game mammals observed on the site were the pronghorn antelope and mule deer.

The only aquatic habitat that may be affected by remedial action at the Maybell site is along Lay Creek. Numerous small fish were observed in this creek on July 30, 1986, and September 16, 1992 (TAC, 1986; 1992). The limited 
fishery information for Lay Creek indicates that the dominant species are the fathead minnow (Pimephales promelas) and plains killifish (Fundulus kansae), both of which are non-native species (Martinez, 1986).

\subsection{PROPOSED BORROW SITES}

The Rob Pit overburden pile is on BLM-administered land and is within the designated site boundary and shares the same habitat, sagebrush-steppe, as the Maybell tailings site. The Juniper Mountain Limestone Quarry is in open juniper woods; pinon pine is rare in this area. The shrub layer is dominated by big sagebrush, and species such as broom snakeweed and rabbitbrush are also common. The Maybell gravel source is on a terrace above the Yampa River and has previously been used as a borrow site. Vegetation is sparse at the Maybell gravel source, with rabbitbrush being the most predominant shrub and low-growing annuals as the ground cover.

The Craig Basalt Quarry is an existing quarry and is not considered further in regards to flora and fauna. Elk use of the Juniper Mountain Limestone Quarry is common, as evidenced by the abundant signs observed. Wildlife use of the Maybell gravel source borrow site is light, given the sparse vegetative growth in this area. There is a large cattail and Carex sp. wetland along the western border of the site, and an irrigation ditch bordered by wetland vegetation occurs along the southern border. The Yampa River is along the northern edge of this site and is bordered by riparian-wetland vegetation.

\section{$2.4 \quad$ IMPACTS TO FLORA AND FAUNA}

Flora and fauna would be affected directly and indirectly by remedial action. Direct effects would be the destruction of habitat during the cleanup of contaminated land. Indirect effects would arise from increased fugitive dust, noise levels, and human activity which may reduce wildlife use in habitat adjacent to the direct impact zone. The duration of the direct effects would depend on the level of restoration. Indirect effects would be for the duration of the remedial action or less.

This section evaluates remedial action impacts to upland, wetland, and game species. The evaluation of impacts to federally listed threatened and endangered species and to federal candidate species is presented in Section 3.0.

Implementation of the proposed action would result in the disturbance of approximately 270 ac (110 ha) of land. The areas that would be disturbed include the disposal site and associated windblown and waterborne contaminated areas and the three proposed borrow sites. Past mining activities have disturbed much of the land at and surrounding the tailings pile. Two plant community types in the vicinity of the disposal site would be impacted:

1) areas dominated by vegetation indicative of disturbed habitat (160 ac [65 ha]), and 2) desert shrub habitat dominated by big sagebrush. The largest segment of desert shrub habitat occurs in the windblown contaminated area and 
around the former mill site (70 ac [28 ha]). The clearing of contaminated, but previously undisturbed, land during the remedial action would constitute an unavoidable impact on vegetation and wildlife. The magnitude of this impact depends on the quantity and quality of habitat that would be impacted and the measures taken to restore this habitat. In terms of habitat quality for wildlife, the disturbed lands represent areas of least quality and desert shrub habitat represents habitat of higher quality.

Game species that would be impacted by remedial action activities include the mule deer, pronghorn antelope, and sage grouse. The approximate 214 ac (87 ha) (tailings pile, mill yard area, and windblown and waterborne contaminated areas) of land in the disposal site vicinity that would be cleared are equivalent to range used by 11 mule deer, assuming a density of 32 deer per square mile (mi ${ }^{2}$ ) (12 deer per square kilometer $\left[\mathrm{km}^{2}\right]$ ) (CDOW, 1985a). The pronghorn antelope is common in the area, and it uses the processing site area, including the tailings pile, more than the surrounding desert shrub habitat. As with the mule deer, approximately 214 ac ( 87 ha) of wintering habitat for the pronghorn antelope would be lost, which is equivalent to the range used by three pronghorn antelope assuming a density of eight antelope per $\mathrm{mi}^{2}$ (three antelope per $\mathrm{km}^{2}$ ) (CDOW, 1985b). Sage grouse use the desert shrub habitat for brood habitat and year-round use; $113 \mathrm{ac}$ (46 ha) used by the sage grouse would be cleared in the tailings pile area.

Following remedial action, the 66-ac (27-ha) disposal cell would not be suitable habitat for most wildlife; the topslope and the sideslopes of the disposal cell would be rock-covered. The duration of the impact on game species due to the clearing of the land adjacent to the disposal cell would depend on the habitat restoration plan. Restoring the habitat to the desert shrub type would take 4 to 5 years, while creation of grass-dominated habitat would take about 2 years.

Waterborne contamination is present in wetland habitat along Johnson Wash and Lay Creek. Approximately 9 ac (3.6 ha) are contaminated in Johnson Wash and 22 ac ( $9 \mathrm{ha}$ ) are contaminated in Lay Creek. The DOE proposes to clean up only two areas along Johnson Wash and Lay Creek, and apply supplemental surface cleanup standards to the remaining contamination. The majority of contamination along these two drainages would be left in place. Therefore, none of the 31 ac (13 ha) of wetland habitat along Johnson Wash and Lay Creek would be impacted during the remedial action.

All three proposed off-site borrow locations contain disturbed land as they are existing operations. The necessity of expanding any of these borrow sites in order to obtain the required volume of disposal cell construction materials cannot be determined at this time. The need for expansion would be dependent upon the current level of usage for local projects and the unknown local usage prior to the remedial action at the Maybell site. Assuming that some expansion of the borrow sites is required for this remedial action, additional impacts to flora and fauna would be minimal because the sites have already been disturbed. 


\subsection{THREATENED AND ENDANGERED SPECIES}

The listing of threatened and endangered species and other species of concern that may occur at the Maybell site was obtained through consultation with the FWS (refer to Attachment 1, Appendix 1 for FWS letters). This process identified 12 species that may occur at the site (Table 3.1). Of these, seven are federally listed species and five are federal candidate species (Rose, 1992).

\section{$3.1 \quad$ FEDERALLY LISTED SPECIES}

The bald eagle (Haliaeetus leucocephalus) is also listed as endangered by the state of Colorado. The bald eagle winters in northwest Colorado, especially in riparian areas, and also nests occasionally along the Yampa River. Two pairs of bald eagles nested near Craig, Colorado, in 1992; one pair fledged two young and the other pair did not produce young. These are the closest nesting bald eagles in the area (Petch, 1992). An aerial survey (fixed wing) of all areas that may be disturbed during remedial action indicated that the bald eagle does not nest near the site (Petch, 1992; Lockhart, 1986b; Opdycke, 1986) and would therefore not be impacted. However, the bald eagle occurs along the Yampa River during the winter near the Maybell gravel source borrow site.

Approximately 25 to 50 wintering birds may use the river length between Maybell and Sunbeam, Colorado (Petch, 1992). Winter concentration areas such as nocturnal roosts do not occur near the Maybell gravel source due to the lack of stands of mature cottonwood trees. In addition, the vegetation consists of early successional shrubs, grasses, and herbs. Therefore, the clearing of this area would not eliminate potential roost sites for wintering eagles.

Most of Moffat County, Colorado, including the Maybell site, is within the historic range of the black-footed ferret (Mustela nigripes) (CDOW, 1978). This species is listed also as a Colorado endangered species. There have been no confirmed sightings of this species in Colorado in recent decades. The black-footed ferret is highly dependent on the prairie dog for food, and it uses prairie dog holes to live in and raise its young. For this reason, all prairie dog towns are considered potential black-footed ferret habitat (Clark et al., 1984). Ground surveys indicated that the prairie dog does not occur at the Maybell site or the on- and off-site proposed borrow areas (TAC, 1986; DOE, 1983).

Therefore, it is very unlikely that the black-footed ferret occurs at the Maybell site and remedial action activities would not affect this species.

The Yampa River is the only large river in the Colorado River basin that has not been substantially altered by water development projects. Native fish species dominate the Yampa River fisheries, which indicates a relatively unaltered environment. Rivers in the Colorado River basin that have been substantially altered by dams and other human uses typically show a dominance of nonnative fish species. Historically, the Colorado squawfish (Ptychocheilus lucius), humpback chub (Gila cypha), bonytail chub (Gila elegans), and razorback sucker (Xyrauchen texanus) were common to abundant in the Colorado River basin, 
including the Yampa River. These species are now threatened with extinction due to "the combined effects of habitat loss; regulation of natural stream flow, temperature, and sediment regimes; proliferation of introduced competitors and predators; and other man-induced disturbances" (Tyus and Karp, 1989). The Colorado squawfish, humpback chub, and razorback sucker are also state of Colorado endangered species. The Yampa River has had relatively little human development, but introduced fish species such as the channel catfish (/ctalurus punctatus), northern pike (Esox lucius), and walleye (Stizostedion vitreum) may be competing for food and feeding on the young of the endangered species (Tyus and Beard, 1990; Tyus and Nikirk, 1990).

The Colorado squawfish appears to reach its greatest abundance in the main stream of the Colorado and Yampa rivers (Haynes et al., 1984). Intensive sampling for larval squawfish in $121 \mathrm{mi}(195 \mathrm{~km})$ of the Yampa River resulted in squawfish fry being observed only in the lower $18.5 \mathrm{mi}(30 \mathrm{~km})$ of the river (Haynes et al., 1984). Data indicate that resident squawfish upstream from this area migrate to this lower $18.5 \mathrm{mi}(30 \mathrm{~km})$ section of the Yampa River to spawn in late June and early July (Tyus and McAda, 1984). The fish then move back upstream in late July to their resident area. Squawfish have been captured in the Yampa river in the area of the Maybell gravel source. This site is located near a portion of the river used as wintering habitat by the squawfish (Tyus and Karp, 1989). The excavation of material from the Maybell gravel source would not impact the Yampa River, and therefore would not have a direct effect on the Colorado squawfish.

The humpback chub is restricted to swift, deep water areas of rivers, mainly in canyons. Currently, the humpback chub occurs in the Grand Canyon of the lower Colorado River basin and in the upper Colorado River basin from Westwater Canyon to Ruby Canyon.

The bonytail chub is most common in the open river area of large river channels. Currently, the bonytail chub is found in Lake Mohave of the lower Colorado River basin and in the Gray Canyon on the Green River.

The humpback chub occurs in the lower $56 \mathrm{mi}(90 \mathrm{~km})$ of the Yampa River; however, it is questionable that the bonytail chub occurs in the river (Tyus and Karp, 1989). Since the humpback chub does not occur anywhere near the Maybell gravel source and the bonytail chub probably does not occur in the river, remedial action activities would not directly affect these species.

The historic range of the razorback sucker includes part of the Yampa River downstream from its confluence with the Little Snake River; this species may still occur in the lower Yampa River (Behnke and Benson, 1982). However, recent fish collections in the Yampa River failed to result in the capture of any razorback suckers (Wick et al., 1985). Collection sites included locations near the Maybell gravel source. This information indicates that the razorback sucker does not occur in the Yampa River near the Maybell gravel source. A recent compilation of fisheries data for the Yampa River indicates that the razorback 
sucker occurs only in the lower $13 \mathrm{mi}(21 \mathrm{~km})$ of the river (Tyus and Karp, 1989). Therefore, remedial action activities at the Maybell gravel source would have no direct effect on the razorback sucker since it does not occur in this area of the Yampa River.

The Ute ladies'-tresses (spiranthes diluvialis) is a very rare plant species and was listed as a threatened species in 1992 (FWS, 1992a). Little is known about its habitat requirements or population ecology. It is known to occur in seasonally moist soils and wet meadows near springs, lakes, and perennial streams at elevations below $6500 \mathrm{ft}(2000 \mathrm{~m})$ in Utah, Colorado, and Nevada. The closest population to the Maybell site is at the Dinosaur National Monument in Utah (Jennings, 1990). It occurs in areas where the vegetation is relatively open and not overgrazed. All wetlands regulated by the COE, as well as some drier sites, are potential habitat for this species (FWS, 1992b). Based on this information, the 31 ac (13 ha) of contaminated wetlands along Johnson Wash and Lay Creek would qualify as potential habitat for this species (see Figure 2.1). In addition, the Maybell gravel source may also be potential habitat, because it is in the floodplain of the Yampa River.

The DOE intends to apply supplemental surface cleanup standards to the majority of the contaminated wetland areas along Johnson Wash and Lay Creek. These wetlands would not be cleaned up because the levels of contamination are relatively low and the ecological value is high. Therefore, remedial action activities at the Maybell site would not affect the potential habitat for the Ute ladies'-tresses along these two streams.

There is a possibility that the supplemental surface cleanup standards application with the Nuclear Regulatory Commission would be turned down and all contaminated areas along Johnson Wash and Lay Creek would have to be remediated. The contingency plan to address this possibility shall be to conduct a survey in 1994 for the Ute ladies'-tresses along the two drainages. Surveys for this species would also be conducted at the Maybell gravel source borrow site in 1994. A survey report including all the required information (FWS, 1992a) would be submitted to the FWS following the completion of the surveys.

\subsection{FEDERAL CANDIDATE SPECIES}

The loggerhead shrike (Lanius ludovicianus) occurs as a breeding species throughout most of Colorado including the Maybell site area (Kingery and Graul, 1978). It prefers open country with patches of trees and shrubs, and in Colorado nests in desert shrub, short-grass prairie, agricultural lands, and riparian areas (FWS, 1992c; Kingery and Graul, 1978). Historically, this species was considered a common to fairly common breeding species in Colorado (Kingery and Graul, 1978) and nearby Utah (Cook, 1984). However, this species has declined steadily over most of its range, including Colorado, in recent years (Robbins et al., 1986; Ehrlich et al., 1988) and is considered a 
candidate species by the FWS (FWS, 1992C) as well as being designated as a threatened species in Canada and in numerous states (Robert and Laporte, 1991).

The reasons for the loggerhead shrike population decline are not clear. Robert and Laporte (1991) indicate that changes in agricultural practices that have resulted in a reduction in pasture lands and hedgerows, as well as regrowth of forested lands, have contributed to the decline of this species in Canada. However, these authors did note that many areas of suitable nesting habitat for this species are not being used. Brooks and Temple (1990) observed good nesting success for the loggerhead shrike and adequate breeding habitat in Minnesota, yet they predict that this species will decline 20 percent per year. Brooks and Temple (1990) concluded that habitat alteration, in the form of extensive conversion of pasture lands and old fields to row crops in the shrikes' wintering grounds in the Gulf Coast states, may be at least partially responsible for the recent declines of the northern populations. Since the northern Colorado loggerhead shrike population is migratory and likely winters south of Colorado in Texas, New Mexico, and Arizona (Root, 1988), alterations to its winter range may be contributing to its decline.

The loggerhead shrike nests in sagebrush and riparian plant communities, both of which occur at the Maybell site. Wildlife surveys have been conducted in the spring (TAC, 1989), summer (DOE, 1983; TAC, 1986, 1987, and 1990), and the fall (TAC, 1992) at the Maybell site over the last 10 years, and the loggerhead shrike has never been observed. In addition, a Colorado Breeding Bird Atlas census block near the site was surveyed in 1992 and no northern shrikes were recorded (Toolen, 1992). Therefore, it is very unlikely that this species has or would occur at or near the Maybell tailings site or associated borrow sites. Therefore, remedial action activities at the Maybell site will not impact this species.

The northern goshawk (Accipiter gentilis) is a year-round resident in northwest Colorado (Kingery and Graul, 1978). In the west, this species nests in mature conifer forests such as those dominated by Douglas fir and ponderosa pine (Call, 1978; Moore and Henny, 1983). Remedial action activities at the Maybell site do not include conifer forest habitat. The Juniper Mountain Limestone Quarry and the Craig Basalt Quarry contain conifer forest habitat. Both of the rock quarries are existing operations and have the necessary permits from the BLM. Therefore, remedial action activities would not further impact the northern goshawk.

The Columbian sharp-tailed grouse (Tympanuchus phasianellus columbianus) has been reduced to remnant populations in most of its range and has been extirpated from Oregon, California, and Nevada. The reasons for this decline are thought to be agricultural development and grazing (Marks and Marks, 1988). Historically, this species occurred in much of eastern Moffat County north, south, and east of Craig, Colorado. This range did not include the Maybell site (Rogers, 1969). In recent years, population levels of the Columbian sharp-tailed 
grouse have declined in Moffat County in its historical range because of habitat destruction due to coal strip mining, agriculture, and home site development (Giesen, 1981).

Information on habitat use of the Columbian sharp-tailed grouse indicates it uses mountain shrub (dominated by chokecherry [Prunus sp.] and service berry [Amelanchier sp.]) and wooded riparian habitats in the winter (Marks and Marks, 1988). Klott and Lindzey (1990) studied brood habitats of the sage grouse and the Columbian sharp-tailed grouse occupying the same range, and determined that the sage grouse broods were usually in the sagebrush/grass habitat and the sharp-tailed grouse were in the mountain shrub habitat that occurred at the transition zone between the sagebrush habitat and forested area. Studies of Columbian sharp-tailed grouse habitat use in Moffat County, Colorado, indicated that this species selected mountain shrub habitat with snowberry having the highest importance of low shrub species. This species was also closely associated with serviceberry, especially in the winter (Gieson, 1987).

Based on the historic range of the Columbian sharp-tailed grouse and its preference for mountain shrub habitat, which does not occur at the Maybell site, it is likely that the species does not occur at the site. Therefore, remedial action activities would not affect this species.

The flannelmouth sucker (Catostomus latipinnis) is an indigenous fish species in the Yampa River (Wick et al., 1985). It, like the Colorado squawfish and other river fish, uses the lower 100 yards $(91 \mathrm{~m})$ of Lay Creek during periods of high water in the spring (Nesler, 1992). This species has been declining in the lower Colorado River Basin, but there is no evidence that its numbers have declined in the Yampa River (Nesler, 1992). The only activity associated with remedial action at the Maybell site will take place near the Yampa River at the Maybell borrow site. These activities will not impact the Yampa River and therefore will not impact the flannelmouth sucker. This species is not subject to the jeopardy determination regarding the depletion of water from the Upper Colorado River Basin because it is not a listed species. Consequently, the use of water for remedial action will not have an indirect impact on the flannelmouth sucker.

The Wetherill milkvetch (Astragalus wetherillii) is a low perennial plant discovered in 1892. This species is found in six counties in Colorado, including Moffat County. It occurs in small scattered populations between elevations 4620 and $7700 \mathrm{ft}(1410$ and $2350 \mathrm{~m})$. This milkvetch is frequently found growing in poor soils in recently disturbed sites next to drainages or along old roads (Bunin, 1992). Typical habitat in the Estes Gulch area near Rifle, Colorado, is in open areas in the pinon juniper woods on slopes along drainages. This species seems to prefer open areas with shallow or disturbed soil (Coleman, 1992).

A field survey for the Wetherill milkvetch was conducted in the tailings pile area in August 1993. No populations of this species were found during the survey. The closest known population of the Wetherill milkvetch to the Maybell site is in 
the Juniper Canyon area above the Yampa River in open pinon-juniper woods. This population is approximately $5 \mathrm{mi}(8.0 \mathrm{~km})$ south of the tailings pile (Bunin, 1992). The only other population in Moffat County is near the city of Craig, Colorado.

Of these five federal candidate species, it was determined that the loggerhead shrike, northern goshawk, Columbian sharp-tailed grouse, and the Wetherill milkvetch do not occur in the site area. The flannelmouth sucker does occur in the Yampa River near the proposed Maybell gravel source borrow site.

\subsection{SUMMARY}

Remedial action activities at the Maybell site would not have a direct effect on the endangered fish of the Yampa River. However, remedial action at the Maybell site may have an indirect impact on these endangered fish. The FWS has determined that an upper Colorado River basin-wide (which includes the Yampa River) jeopardy situation has existed since 1978 (FWS, 1987) for the endangered fish species discussed above. Depletion of water within the upper Colorado River basin would have a negative impact on these species and would result in a "may affect" determination by the FWS.

The total volume of water required during the 19-month remedial action period is estimated to be $19,100,000$ gallons (TAC, 1991) $\left(72,000 \mathrm{~m}^{3}\right)$, or 59 acrefeet (ac-ft). The average annual volume of water required is estimated to be $29.5 \mathrm{ac}-\mathrm{ft}$. Since some of the construction water may be obtained from the Yampa River or, potentially, from aquifers hydraulically connected to the Yampa River, this water depletion would be subject to the "may affect" determination by the FWS. Under the Endangered Species Act of 1973 (PL 93-205), as amended, this determination requires the initiation of a formal consultation with the FWS. According to the "Recovery Implementation Program for Endangered Fish Species in the Upper Colorado River Basin" (FWS, 1987), water depletion subject to a "may affect" determination would require a one-time payment of $\$ 11.98$ (or the most current amount, which is adjusted annually for inflation) per acre-foot by the DOE to the FWS for the estimated average annual volume of $29.5 \mathrm{ac}$-ft of water used. The funds would be used to acquire water rights and otherwise support the recovery of the endangered fish of the Upper Colorado River Basin. 


\subsection{REFERENCES}

BLM (Bureau of Land Management), 1986. "Little Snake Resource Management Plan and Environmental Impact Statement," BLM, Craig, Colorado.

BOR (Bureau of Reclamation), 1981. "Resource and Potential Reclamation Evaluation--Lay Creek Study Area," BOR, Salt Lake City, Utah.

Behnke, R. J., and D. E. Benson, 1982. "Endangered and Threatened Fishes of the Upper Colorado River Basin," Cooperative Extension Service, Bulletin 503A, Colorado State University, Fort Collins, Colorado.

Bernard, S. R., and K. F. Brown, 1978. "Distribution of Mammals, Reptiles, and Amphibians by BLM Physiographic Regions and A. W. Kuchlers Associations for the Eleven Western States," U.S. Department of the Interior, Bureau of Land Management, Denver, Colorado.

Brooks, B. L., and S. A. Temple, 1990. "Dynamics of a Loggerhead Shrike Population in Minnesota," Wilson Bulletin, Vol. 102, No. 3, pp. 441-450.

Bunin, J. E., 1992. "Status Report for Astragalus wetherillii," U.S. Fish and Wildlife Service, Golden, Colorado.

CDOW (Colorado Division of Wildlife), 1985a. "Results of the 1985 DAU D-Z Aerial Deer Quadrant Census," Colorado Division of Wildlife, Grand Junction, Colorado.

CDOW (Colorado Division of Wildlife), 1985b. "Wildlife Resource Inventory SystemScenario, Pronghorn Antelope Inventory System, Data Analysis Unit PA34," Colorado Division of Wildlife, Grand Junction, Colorado.

CDOW (Colorado Division of Wildlife), 1978. "Essential Habitat for Threatened or Endangered Wildlife in Colorado," Colorado Division of Wildlife, Denver, Colorado.

Call, M. W., 1978. "Nesting Habitats and Surveying Techniques for Common Western Raptors," Bureau of Land Management, Technical Note TN-316, Denver, Colorado.

Clark et al. (T. W. Clark, T. M. Campbell, M. H. Schroeder, and L. Richardson), 1984. "Handbook of Methods for Locating Black-Footed Ferrets," U.S. Bureau of Land Management, Wildlife Technical Bulletin No. 1, Cheyenne, Wyoming.

Coleman, L., 1992. Biologist with the Bureau of Land Management, Glenwood Springs, Colorado, personal communication with Charles J. Burt, Environmental Services Department, Jacobs Engineering Group Inc., Albuquerque, New Mexico, October 15, 1992.

Cook, A. G., 1984. "Birds of the Desert Region of Uinta County, Utah," Great Basin Naturalist, Vol. 44, No. 4, pp. 584-620. 
Cowardin et al. (L. M. Cowardin, V. Carter, F. C. Golet, and E. T. LaRoe), 1979. "Classification of Wetlands and Deepwater Habitats of the United States," FWS/OBS-79/31, Office of Biological Services, U.S. Fish and Wildlife Service, Washington, D.C.

DOE (U.S. Department of Energy), 1983. "Environmental Assessment of Remedial Actions on the Uranium Mill Tailings at the Maybell Site, Moffat County, Colorado," DOE/EA-0347, August 1983, DOE UMTRA Project Office, Albuquerque Operations Office, Albuquerque, New Mexico.

Davis, G., 1989. U.S. Army Corps of Engineers, Grand Junction, Colorado, personal communication with Charles J. Burt, Environmental Services Department, Jacobs Engineering Group Inc., Albuquerque, New Mexico, May 5, 1989.

Ehrlich et al. (P. R. Ehrlich, D. S. Dobkin, and D. Wheye), 1988. The Birders Handbook, Simon and Schuster, Inc., New York.

FWS (U.S. Fish and Wildlife Service), 1992a. "Endangered and Threatened Wildlife and Plants; Final Rule to List the Plant Spiranthes diluvialis (Ute Ladies'-Tresses) as a Threatened Species," 50 CFR Part 17, in Federal Register, Vol. 57, No. 12, pp. 2048-2053.

FWS (U.S. Fish and Wildlife Service), 1992b. "Interim Survey Requirements for Spiranthes diluvialis," FWS, Salt Lake City, Utah.

FWS (U.S. Fish and Wildlife Service), 1992c. "Loggerhead Shrike, Lanius /udovicianus," U.S. Fish and Wildlife Service, Bismarck, North Dakota.

FWS (U.S. Fish and Wildlife Service), 1987. "Recovery Implementation Program for Endangered Fish Species in the Upper Colorado River Basin," FWS, Region 6, Denver, Colorado.

Giesen, K. M., 1987. "Population Characteristics and Habitat Use by Columbian Sharp-Tailed Grouse in Northwest Colorado," Colorado Division of Wildlife, Wildlife Research Report 01-03-045 (W-37-R), Fort Collins, Colorado.

Giesen, K. M., 1981. "Distribution and Status of Mountain Sharp-Tailed Grouse," Colorado Division of Wildlife, Wildlife Research Report W-37-R-34, Fort Collins, Colorado.

Grahm, V., 1986. Colorado Division of Wildlife, Grand Junction, Colorado, personal communication with Charles J. Burt, Environmental Services Department, Jacobs Engineering Group Inc., Albuquerque, New Mexico, August 29, 1986.

Haynes et al. (C. M. Haynes, T. A. Lytle, E. J. Wick, and R. T. Muth), 1984. "Larval Colorado Squawfish (Ptychocheilus lucius Girard) in the Upper Colorado River Basin, Colorado, 1979-1981," in The Southwestern Naturalist, Vol. 29, No. 1, pp. 21-33. 
Jennings, W. F., 1990. "Final Report Colorado Natural History Small Grants Program Prepared for the Nature Conservancy: Species Studies, Spiranthes diluvialis," Louisville, Colorado.

Kingery, H. E., and W. D. Graul, 1978. "Colorado Bird Distribution Latilong Study," Colorado Division of Wildlife, Denver, Colorado.

Klott, J. H., and F. G. Lindzey, 1990. "Brood Habitats of Sympatric Sage Grouse and Columbian Sharp-Tailed Grouse in Wyoming," in Journal of Wildlife Management, Vol. 54, No. 1, pp. 84-88.

Kuchler, A. W., 1975. "Potential Natural Vegetation of the Conterminous United States," American Geographic Society Special Publication No. 36, New York, New York (Map).

Lockhart, M., 1986a. U.S. Fish and Wildlife Service, Grand Junction, Colorado, personal communication with Charles J. Burt, Environmental Services Department, Jacobs Engineering Group Inc., Albuquerque, New Mexico, May 13, 1986.

Lockhart, M., 1986b. U.S. Fish and Wildlife Service, Grand Junction, Colorado, personal communication with Charles J. Burt, Environmental Services Department, Jacobs Engineering Group Inc., Albuquerque, New Mexico, March 5, 1986.

Marks, J. S., and V. S. Marks, 1988. "Winter Habitat Use by Columbian Sharp-Tailed Grouse in Western Idaho," in Journal of Wildlife Management, Vol. 52, No. 4, pp. 743-746.

Martinez, P., 1986. Colorado Division of Wildlife, Grand Junction, Colorado, personal communication with Charles J. Burt, Environmental Services Department, Jacobs Engineering Group Inc., Albuquerque, New Mexico, September 18, 1986.

Mezei, N., 1992. U.S. Army Corps of Engineers, Grand Junction, Colorado, personal communication with Charles J. Burt, Environmental Services Department, Jacobs Engineering Group Inc., Albuquerque, New Mexico, September 17, 1992.

Moore, K. R., and C. J. Henny, 1983. "Nest Site Characteristics of Three Coexisting Accipiter Hawks in Northeastern Oregon," Raptor Research, Vol. 17, No. 3, pp. 65-76.

Nesler, T., 1992. Colorado Division of Wildlife, Fort Collins, Colorado, personal communication with Charles J. Burt, Environmental Services Department, Jacobs Engineering Group Inc., Albuquerque, New Mexico, October 19, 1992.

Opdycke, J., 1986. "Wetland and Raptor Inventory of the Maybell Site," prepared by the U.S. Fish and Wildlife Service, Grand Junction, Colorado, for the U.S. Department of Energy, UMTRA Project Office, Albuquerque Operations Office, Albuquerque, New Mexico. 
Petch, B., 1992. Colorado Division of Wildlife, Maybell, Colorado, personal communication with Charles J. Burt, Environmental Services Department, Jacobs Engineering Group Inc., Albuquerque, New Mexico, October 12, 1992.

Robbins, et al. (C. S. Robbins, D. Bystrak, and P. H. Geissler), 1986. "The Breeding Bird Survey: Its First Fifteen Years, 1965-1979," U.S. Fish and Wildlife Services Resource Publication 157, Washington D.C.

Robert, M., and P. Laporte, 1991. "History and Current Status of the Loggerhead Shrike in Quebec," Canadian Wildlife Service Progress Note No. 196, Quebec, Canada.

Rogers, G. E., 1969. "The Sharp-Tailed Grouse in Colorado," Colorado Game, Fish, and Parks, Technical Publication 23.

Root, T., 1988. Atlas of Wintering North American Birds, An Analysis of Christmas Bird Count Data, The University of Chicago Press, Chicago, Illinois.

Rose, K. L., 1992. U.S. Department of the Interior, Fish and Wildlife Service, Grand Junction, Colorado, personal communication to James Gibb, Jacobs Engineering Group Inc., Albuquerque, New Mexico, September 21, 1992.

Rose, K. L., 1990. U.S. Department of the Interior, Fish and Wildlife Service, Grand Junction, Colorado, personal communication to Mark L. Matthews, U.S. Department of Energy, Albuquerque, New Mexico, November 13, 1990.

TAC (Technical Assistance Contractor), 1992. "Unpublished Field Notes, Maybell, Colorado, Uranium Mill Tailings Site," unpublished report prepared by the Technical Assistance Contractor (Jacobs-Weston Team), Albuquerque, New Mexico, for the U.S. Department of Energy, UMTRA Project Office, Albuquerque Operations Office, Albuquerque, New Mexico.

TAC (Technical Assistance Contractor), 1991. "Maybell Disposal Site Fact Sheet," unpublished report prepared by the Technical Assistance Contractor (Jacobs-Weston Team), Albuquerque, New Mexico, for the U.S. Department of Energy, UMTRA Project Office, Albuquerque Operations Office, Albuquerque, New Mexico, December 27, 1991.

TAC (Technical Assistance Contractor), 1990. "Unpublished Field Notes, Maybell, Colorado, Uranium Mill Tailings Site," unpublished report prepared by the Technical Assistance Contractor (Jacobs-Weston Team), Albuquerque, New Mexico, for the U.S. Department of Energy, UMTRA Project Office, Albuquerque Operations Office, Albuquerque, New Mexico.

TAC (Technical Assistance Contractor), 1989. "Unpublished Field Notes, Maybell, Colorado, Uranium Mill Tailings Site," unpublished report prepared by the Technical Assistance Contractor (Jacobs-Weston Team), Albuquerque, New Mexico, for the U.S. Department of Energy, UMTRA Project Office, Albuquerque Operations Office, Albuquerque, New Mexico. 
TAC (Technical Assistance Contractor), 1987. "Unpublished Field Notes, Maybell, Colorado, Uranium Mill Tailings Site," unpublished report prepared by the Technical Assistance Contractor (Jacobs-Weston Team), Albuquerque, New Mexico, for the U.S. Department of Energy, UMTRA Project Office, Albuquerque Operations Office, Albuquerque, New Mexico.

TAC (Technical Assistance Contractor), 1986. "Unpublished Field Notes, Maybell, Colorado, Uranium Mill Tailings Site," unpublished report prepared by the Technical Assistance Contractor (Jacobs-Weston Team), Albuquerque, New Mexico, for the U.S. Department of Energy, UMTRA Project Office, Albuquerque Operations Office, Albuquerque, New Mexico.

Toolen, J., 1992. "Colorado Breeding Bird Atlas Field Card, Atlas Region A, Map Name Maybell, Map Number 4010851," Grand Junction, Colorado.

Tyus, H. M., and J. M. Beard, 1990. "Esox lucius (Esocidae) and Stizostedion vitreum (Percidae) in the Green River Basin, Colorado and Utah," Great Basin Naturalist, Vol. 50, No. 1, pp. 33-39.

Tyus, H. M., and N. J. Nikirk, 1990. "Abundance, Growth, and Diet of Channel Catfish, Ictalurus punctatus, in the Green and Yampa Rivers, Colorado and Utah," The Southwestern Naturalist, Vol. 25, No. 2, pp. 188-198.

Tyus, H. M., and C. A. Karp, 1989. "Habitat Use and Streamflow Needs of Rare and Endangered Fishes, Yampa River, Colorado," U.S. Fish and Wildife Service Biological Report 89(14), Washington, D.C.

Tyus, H. M., and C. W. McAda, 1984. "Migration, Movements, and Habitat Preferences of Colorado Squawfish Ptychocheilus lucius, in the Green, White and Yampa Rivers, Colorado and Utah," in The Southwestern Naturalist, Vol. 29, No. 3, pp. 289-299.

Wick et al. (E. J. Wick, J. A. Hawkins, and C. A. Carlson), 1985. "Colorado Squawfish and Humpback Chub Populations and Habitat Monitoring 1983-1984," Colorado Division of Wildlife, Endangered Wildlife Investigations Final Report SE 3-7, Denver, Colorado.

\section{PUBLIC LAWS}

PL 93-205 (Public Law 93-205), 1973. Endangered Species Act of 1973, 16 USC 1531, December 28, 1973, 93rd Congress of the United States of America, Washington, D.C.

PL 95-604 (Public Law 95-604), 1978. Uranium Mill Tailings Radiation Control Act of 1978, 42 USC 7901, November 8, 1978, 95th Congress of the United States of America, Washington, D.C. 


\author{
ATTACHMENT 1 \\ APPENDIX 1 \\ SECTION 7 CONSULTATION \\ LETTERS FROM THE \\ U.S. FISH AND WILDLIFE SERVICE
}




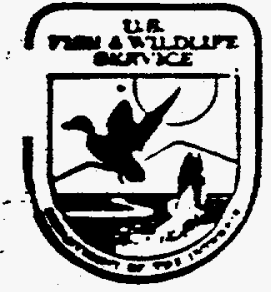

UNITED STATES DEPARTMENT OF THE RTTERIOR FISH AND WILDLIFE SERVICE

FISH AND WRDLIFE ENHANCEMENT

Werrem Colondo Sub-OMice

$529251 \%$ Rond, Suite B. 113

Grnd Junction, CO $81505-6199$

PHONE: (303) 243.2778

FAX: (303) $245-6933$

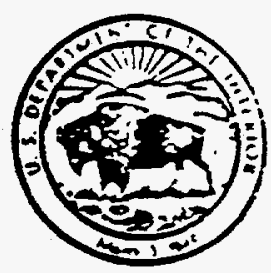

1 REPLY REFER TO:

FWE/CO:DOE-UMTRA

MS 65412 GJ

September 21, 1992

James Gibb

Assistant Project Manager

Jacobs Engineering Group Inc.

5301 Central Avenue N.E., Suite 1700

Albuquerque NM 87108

Dear Mr. Gibb:

This responds to your August 18, 1992, letter regarding additional responsibilities by Jacobs Engineering Group, Inc. (Jacobs) for the reevaluation of threatened and endangered species issues associated with the Maybell Uranium Mill tailings Remedial Action (UMTRA) Project. The last correspondence provided by the Fish and Wildlife Service for this project was the draft biological opinion dated November 13, 1990 (FWS file FWS/GJ-6-CO90-F-010). Your letter states that since the draft biological opinion, completion of planning for the Maybell UMTRA Project was delayed. Due to the time that has elapsed since our last coordination on this project, we are providing a revised list of federally listed and candidate species that should be considered in the renewed planning effort.

\section{FEDERALLY LISTED SPECIES}

Colorado squawfish

Humpback chub

Bonytail chub

Razorback sucker

Bald eagle

Black-footed ferret

Spiranthes diluvialis
Ptrchocheilus lucius

Gila cypha

Gila eleqans

Xyrauchen texanus

Haliaeetus Teucocephalus

Mustela niaripes

Ute ladies'-tresses

\section{FEDERAL CANDIDATE SPECIES}

Loggerhead shrike

Northern goshawk

Columbian sharptailed grouse

Flannelmouth sucker

Astragalus wetheriliti
Lanius ludovicianus

Accipiter gentilis

Iympanuchus phasianellus columbianus Catostomius latipinnis

Wetherill milkvetch

We recommend that Jacobs prepare a new biological assessment for this project. It is our understanding that the only change to the project is the deletion of the Sugarloaf Basin Borrow Site. The re-evaluation should again acdress impacts to the federally listed fish species as a consequence of witer 
depletion. Water depletion charge that must be paid to the National Fish and Wildlife Foundation has increased to $\$ 11.98$ per acre foot.

The information provided for bald eagles and black-footed ferrets in the original biological assessment should be updated. Spiranthes diluvialis was federally listed as threatened on January 17, 1992. This orchid is associated with wet7ands, and searches for this plant can only be conducted from July 20 to August 31. A copy of search requirements for this plant is enclosed.

Some changes have occurred to the list of candiate species. Astragalus wetherillii has typically been found in pinyon pine-juniper and big sagebrush communities, but is sometimes found among oakbrush. Historic localities are known from the Yampa River drainages between elevations of 4,620 and 7,700 feet. This plant can only be found in May and June.

The lead Federal agency for Endangered Species Act (ESA) Section 7 consultation should review their proposed Federal action and determine if the action would affect any listed species. If the determination is "may affect" for listed species, the Federal agency must request in writing formal consultation from our office. At this time, your agency should provide this office a biological assessment and/or any other relevant information used in making the impact determinations.

We wish to also bring to your attention the need for Service review of project effects on other fish and wildife resources. Aside from Endangered Species Act mandates, the Service is charged with a host of statutory responsibilities for protection of other wildlife and their habitats. We routinely evaluate the effects of Federal actions on fish and wildife under authorities of the National Environmental Policy ACt (42 U.S.C. 4321-4347) and the Fish and Wildife Coordination Act (48 Stat. 401 as amended; 16 U.S.C. 661 et seg.).

With respect to the area potentially influenced by the project, the Service has additional concerns over project impacts to wetlands, other high value wildlife habitats (e.g. riparian corridors), and raptors and other migratory birds. Any development of a Federal environmental assessment for the project should include a thorough evaluation of project effects on these fish and wildlife resources as well.

We appreciate your attention to the threatened and endangered species issues associated with continuing planning for this project. Please contact me or Bob Leachman if there are any questions.

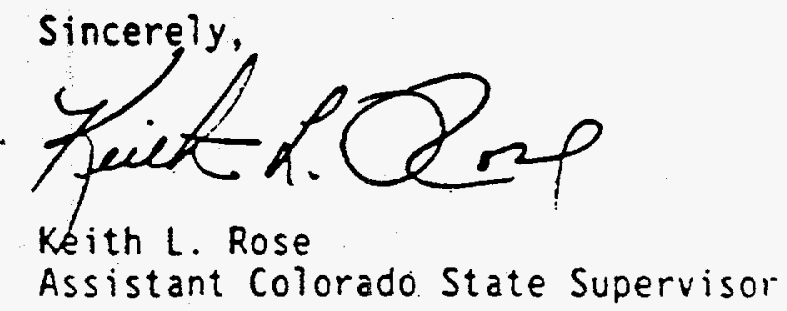




\section{United States Department of the Interior \\ FISH AND WILDLIFE SERVICE \\ COLORADO FIELD OFFICE \\ 730 SIMMS STREET \\ ROOM 292 \\ GOLDEN, COLORADO 80401}

IN REPLY Rarak TO:

FWE/CO:DOE:UMTRA

Mail Stop 65412 Grand Junction 4 : 061990

Mr. Charles J. Burt

Environmental Specialist

Jacobs Engineering Group. Inc.

5301 Central Avenue N.E. Suite 1700

Albuquerque, New Mexico 87108

Dear Mr. Burt:

This responds to your February 26, 1990, letter requesting an update of federally listed species that may be associated with the proposed Uranium Mill Tailings Remedial Action Projects at Slick Rock and Maybell, Colorado.

We have reviewed the lists provided to Jacobs Engineering, Inc. in 1986 and 1988. The following changes should be made:

1) Slick Rock site

ADD: $\quad$ Southwestern otter (Lutra canadensis sonorae) as a Candidate 2 species

DELETE: Long-billed curlew (Numenius americanus)

Swainson's hawk (Buteo swainsoni)

White-faced ibis (Plegadis chihi)

Spotted bat (Euderma maculatum)

2) Maybell site

ADD: $\quad$ Columbian sharptailed grouse (Iympanuchus phasianellus columbianus) and the Western snowy plover (Charadrilis alexandrinus nivosus)

DELETE: Long-billed curlew (Numenius americanus)

Swainson's hawk (Buteo swainsoni)

White-faced ibis (Plegadis chini)

Spotted bat (Euderma maculatum) 
We appreciate the opportunity to update the species lists for these actions. Please contact John Anderson in our Grand Junction office at (303) 243-2778 if there are any questions.

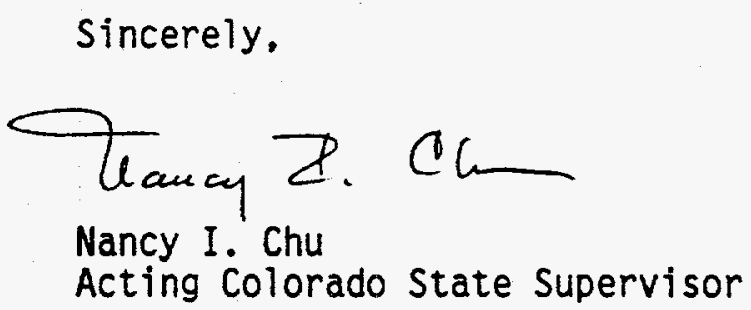

cc: FWS/FWE, Grand Junction FWS/FWE, Salt Lake City CDOW, Grand Junction 


\section{United States Department of the Interior}

FISH AND WILDLIFE SER VICE

COLORADO TIELD OFFICE

730 SIMMS STREET

ROOM 292

COLDEN. COLORADO $\$ 040 ?$

a ear atora no.

(FWE)

Decenber 28, 1988

Charles J. Burt

Environmental Specialist

Jacobs Engineering Group. Inc.

5301 Central Avenue N.E. Sulte 1700

Alburquerque. New Mexico 87108

Dear Mr. Burt:

This responds to your November 21, 1988, letter requesting an update of Federally listed species that may be assoclated with the Droposed Uranium Mill-tailings Remedial Action Projects at Slickrock. Naturita, Gunnison and Maybell. Colorado.

He have reviewed the lists provided to Jacobs Engineering. Inc. In 1986 and 1988. The following changes should be made:

1) Naturite site - Delete the Grand Junction milkvetch.

2) Maypell site - Delete the White River penstemon. Ado the bonytail chub.

3) Gunnison site - Add the Colorado squawfish, humpback chub. and bonytail chub.

The list for the slickrock site needs no changes.

We appreciate the opportunity to update the species lists for these actions. Please contact Bob Leachman of our Grand Junction office at (303) 243-2773 if there are any questions.

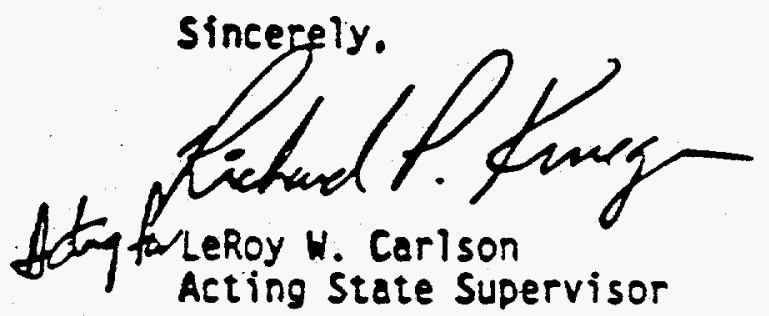

cc: FWS/FWE, Salt Lake City

Official File

Reading file 
ATTACHMENT 2

FLOODPLAIN/WETLANDS ASSESSMENT 
TABLE OF CONTENTS

Section

Page

1.0 INTRODUCTION $\ldots \ldots \ldots \ldots \ldots \ldots \ldots \ldots \ldots \ldots \ldots \ldots \ldots \ldots \ldots \ldots$

2.0 PROJECT DESCRIPTION ......................... 2-1

2.1 Surface contamination ......................... 2-1

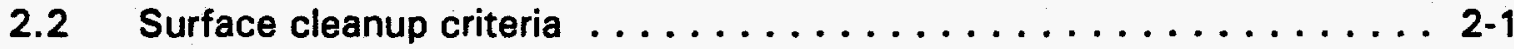

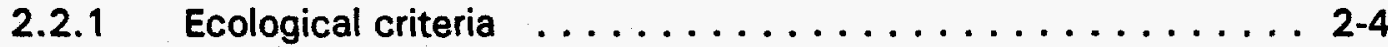

2.2.2 Radiological criteria ................... 2-4

2.2.3 Geomorphological criteria ................. 2-5

2.2 .4 Socioeconomic criteria . . . . . . . . . . . . . 2-6

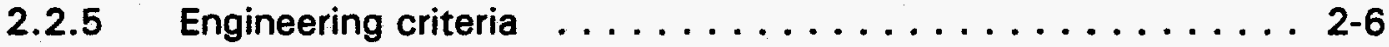

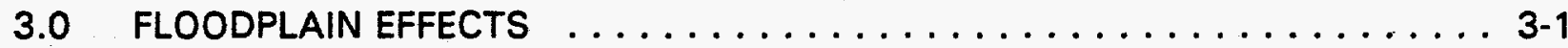

3.1 Affected environments . . . . . . . . . . . . . . . 3-1

3.2 Flood conditions ........................

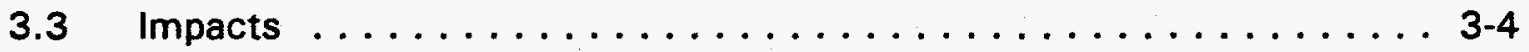

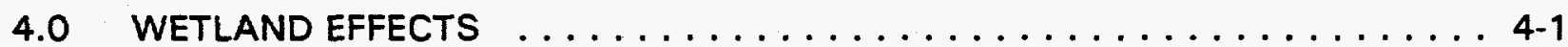

4.1 Affected environment $\ldots \ldots \ldots \ldots \ldots \ldots \ldots \ldots \ldots \ldots \ldots$

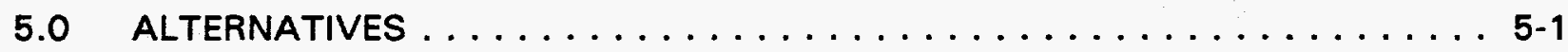

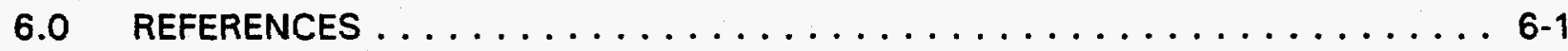




\section{LIST OF FIGURES}

Figure

2.1 Location map of the Maybell tailings site near Maybell, Colorado . . . . . . . 2-2

2.2 Approximate boundaries of radium-226 soil contamination and cleanup at the Maybell tailings site near Maybell, Colorado . . . . . . . . . . . 2-3

3.1 Basin channels contributing flow to Johnson Wash at the Maybell site near Maybell, Colorado . . . . . . . . . . . . . . . . . . . . . 3-2

3.2 Basins contributing flow to Lay Creek (excluding Johnson Wash) east of the Maybell site near Maybell, Colorado . . . . . . . . . . . . . . . 3-3

3.3 Floodplain boundaries for Lay Creek and Johnson Wash during the regional maximum flood (RMF) at the Maybell site near Maybell, Colorado ............................... 3-5

4.1 Wetland plant community types in the contaminated section of Johnson Wash and Lay Creek at the Maybell site near Maybell, Colorado 4-3

\section{LIST OF TABLES}

Table

Page

3.1 Average and peak flood stages for Johnson Wash and Lay Creek . . . . . . . 3-4 


\section{LIST OF ACRONYMS AND ABBREVIATIONS}

$\begin{array}{ll}\text { Acronym } & \text { Definition } \\ \text { ac } & \text { acres } \\ \mathrm{cm} & \text { centimeters } \\ \mathrm{COE} & \text { U.S. Army Corps of Engineers } \\ \mathrm{DOE} & \text { U.S. Department of Energy } \\ \mathrm{EA} & \text { environmental assessment } \\ \mathrm{EPA} & \text { U.S. Environmental Protection Agency } \\ \mathrm{ft} & \text { feet } \\ \mathrm{ft}^{3} / \mathrm{sec} & \text { cubic feet per second } \\ \mathrm{FWS} & \text { U.S. Fish and Wildlife Service } \\ \mathrm{ha} & \text { hectares } \\ \text { in } & \text { inches } \\ \mathrm{km} & \text { kilometers } \\ \mathrm{L} / \mathrm{sec} & \text { liters per second } \\ \mathrm{m} & \text { meters } \\ \mathrm{m}^{3} & \text { cubic meters } \\ \mathrm{mBq} / \mathrm{g} & \text { millibecquerels per gram } \\ \mathrm{mBq} / \mathrm{m}^{2} \mathrm{sec} & \text { millibecquerels per square meter per second } \\ \mathrm{mi} & \text { miles } \\ \mathrm{mrem} & \text { millirem } \\ \mathrm{MSL} & \text { mean sea level } \\ \mathrm{mSv} & \text { millisieverts } \\ \mathrm{pCi} / \mathrm{g} & \text { picocuries per gram } \\ \mathrm{pCi} / \mathrm{m}^{2} \mathrm{sec} & \text { picocuries per square meter per second } \\ \mathrm{Ra}-226 & \text { radium-226 } \\ \mathrm{RMF} & \text { regional maximum flood } \\ \mathrm{Th}-230 & \text { thorium-230 } \\ \mathrm{USGS} & \text { United States Geological Survey } \\ \mathrm{yd} & \text { cubic yards } \\ & \end{array}$




\subsection{INTRODUCTION}

This assessment was prepared to provide an analysis of the potential impacts on floodplains and wetlands from the proposed action (stabilization in place) and alternatives to the proposed action at the Maybell, Colorado uranium processing site. The assessment was prepared pursuant to the U.S. Department of Energy (DOE), Title 10, Code of Federal Regulations, Part 1022, Compliance with Floodplain/Wetlands Environmental Review Requirements (10 CFR 1022). The compliance review requirements are based on Executive Order 11988, Floodplain Management, dated May 24, 1977 (EO 11988), and Executive Order 11990, Protection of Wetlands, dated May 24, 1977 (EO 11990). To comply with these Executive Orders, it is DOE policy, as indicated in 10 CFR 1022, to avoid to the extent possible long- and short-term adverse impacts to floodplains and wetlands. In the context of this assessment, the floodplain is defined as "...at a minimum, that area inundated by a 1 percent or greater chance of flood in any given year. The base floodplain is defined as the 100-year (1.0 percent) floodplain" (10 CFR 1022.4). Wetlands means "those areas that are inundated by surface or ground water with a frequency sufficient to support, and under normal circumstances does or would support, a prevalence of vegetative or aquatic life that requires saturated or seasonally saturated soil conditions for growth or reproduction" (10 CFR 1022.4(v)). 


\subsection{PROJECT DESCRIPTION}

The Maybell tailings site is in Moffat County, Colorado, and is 25 miles (mi) (40 kilometers [km]) west of the city of Craig, Colorado (Figure 2.1). The tailings site is in an upland area at an elevation of approximately 6200 feet (ft) (1900 meters [m]). Johnson Wash, an ephemeral arroyo, drains the site and flows into Lay Creek $1 \mathrm{mi}$ $(1.6 \mathrm{~km})$ south of the site. Lay Creek is a tributary to the Yampa River; its confluence with the Yampa River is about $5 \mathrm{mi}(8 \mathrm{~km})$ southeast of the Maybell tailings site.

The proposed action for the Maybell tailings site is to stabilize the tailings pile at its present location. Contaminated material at the mill yard, windblown area, and areas of elevated contamination along Johnson Wash and an area near the confluence of Johnson Wash and Lay Creek would be stabilized in an above-ground disposal cell constructed on the site at the existing tailings pile. As part of the proposed action, the remaining contamination along Johnson Wash and Lay Creek, specifically wetland areas, would not be cleaned up because supplemental surface cleanup standards would be applied to these areas.

\subsection{SURFACE CONTAMINATION}

Surface contamination at the Maybell site includes the tailings pile and mill yard areas, windblown areas adjacent to the tailings pile, and waterborne contaminated areas along Johnson Wash and Lay Creek. The total estimated volume of contaminated materials is approximately 3.5 million cubic yards $\left(\mathrm{yd}^{3}\right)$ (2.7 million cubic meters $\left[\mathrm{m}^{3}\right]$ ).

The tailings pile contains approximately 2.8 million $\mathrm{yd}^{3}\left(2.1\right.$ million $\left.\mathrm{m}^{3}\right)$ of tailings. The former mill processing yard is located on the north side of the tailings pile and contains an estimated $20,000 \mathrm{yd}^{3}\left(15,000 \mathrm{~m}^{3}\right)$ of contaminated demolition debris from the former mill structures. Areas to the north, west, and south sides of the tailings pile contain approximately 244,000 $\mathrm{yd}^{3}\left(187,000 \mathrm{~m}^{3}\right)$ of contaminated soils.

Wind dispersion has resulted in the contamination of areas around the tailings pile, primarily to the north and east. Approximately $240,000 \mathrm{yd}^{3}\left(184,000 \mathrm{~m}^{3}\right)$ of contaminated soils exist as a result of wind dispersion of contaminated materials.

Surface water flow has dispersed contamination to drainage areas in Johnson Wash and Lay Creek. Approximately $61,000 \mathrm{yd}^{3}\left(47,000 \mathrm{~m}^{3}\right)$ of contaminated materials are present in the two drainages.

\subsection{SURFACE CLEANUP CRITERIA}

The upper portion of Johnson Wash and an upland section near the confluence of Johnson Wash and Lay Creek would be cleaned up as part of the proposed action (Figure 2.2). However, the use of supplemental surface cleanup 


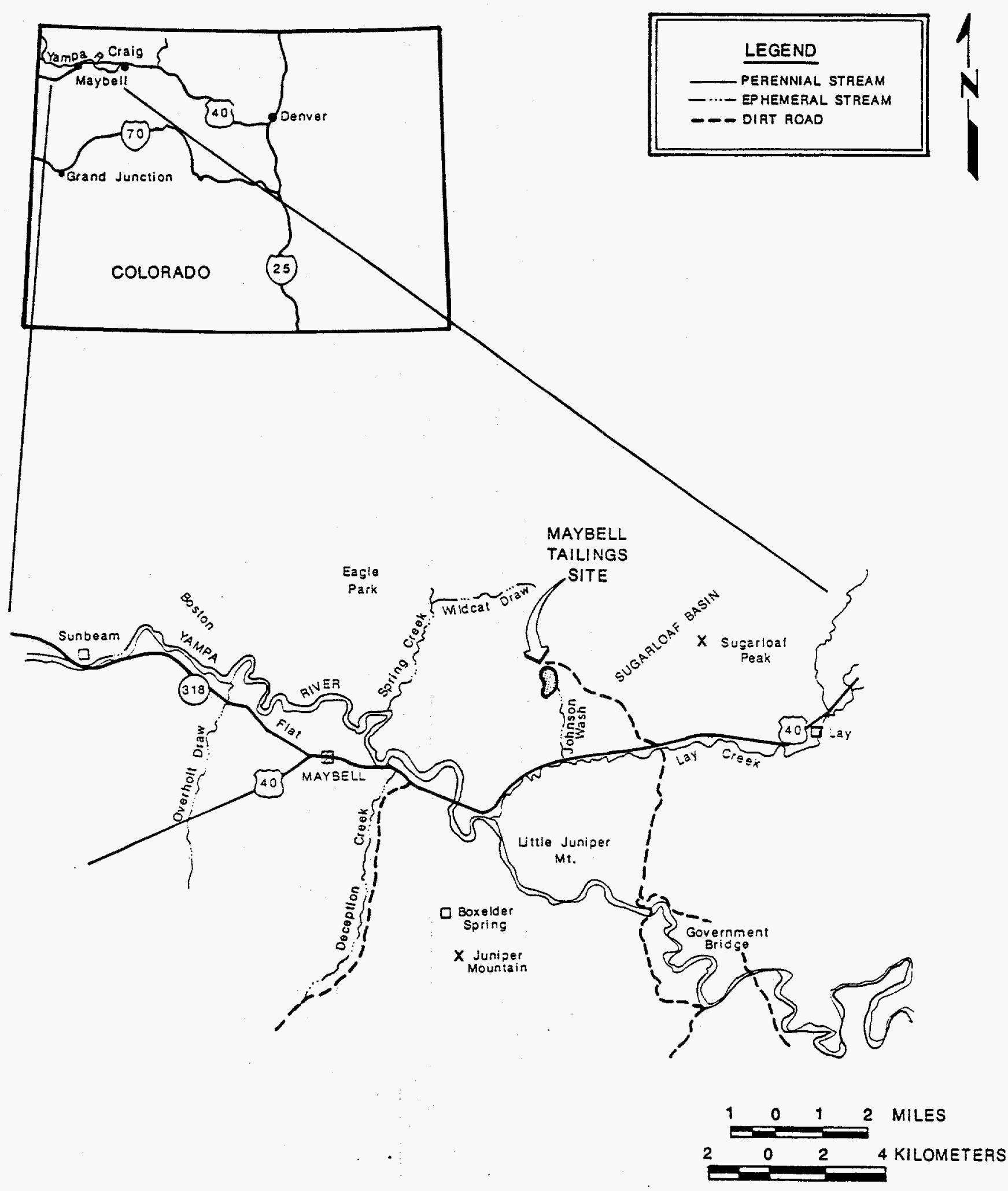

FIGURE 2.1

LOCATION MAP OF THE MAYBELL TAILINGS SITE NEAR MAYBELL, COLORADO 


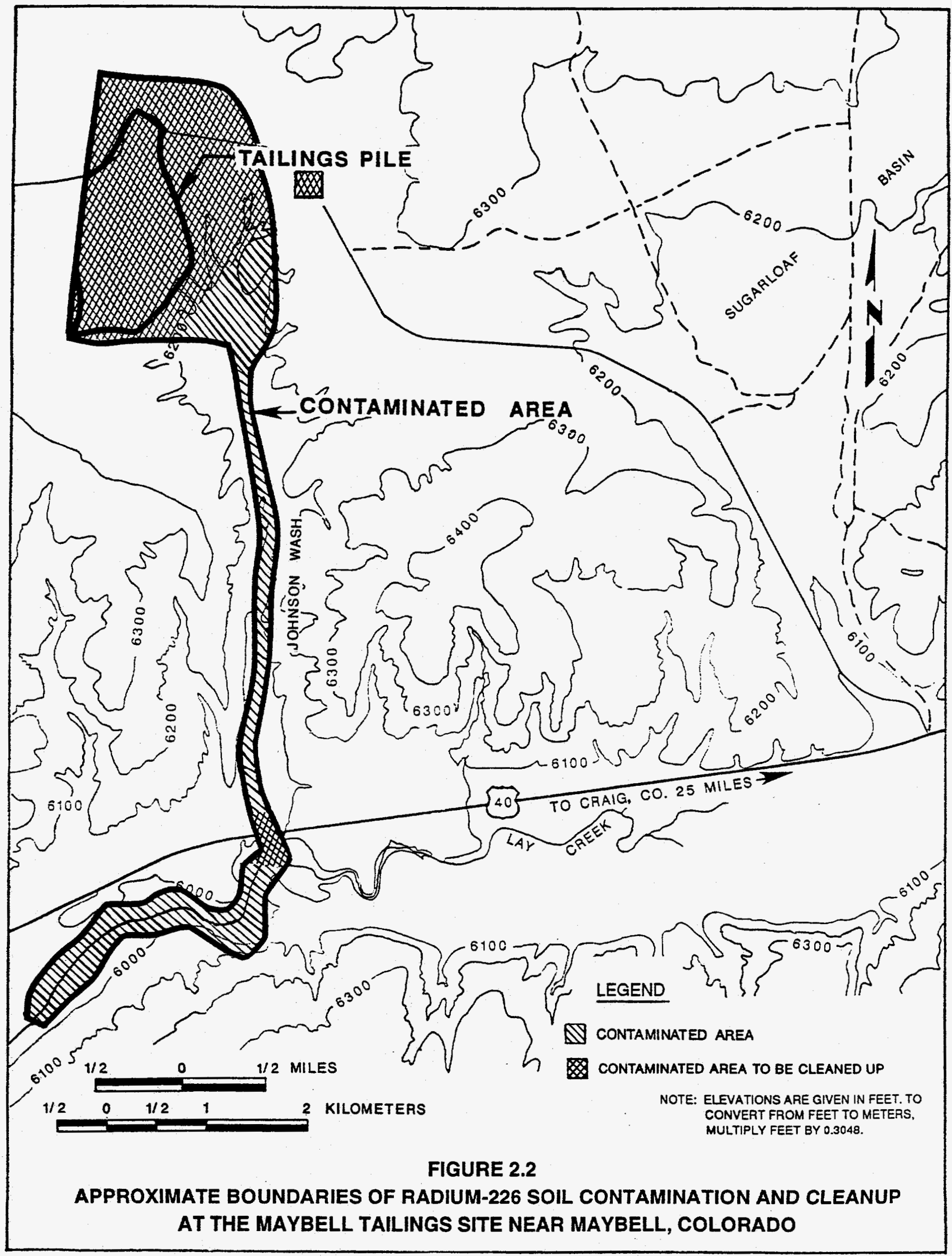


standards would result in no remedial action activities in most of Johnson Wash and all of the contaminated portions of Lay Creek. The rationale for applying supplemental surface cleanup standards to Johnson Wash and Lay Creek is based on ecological, radiological, geomorphological, socioeconomic, and engineering criteria.

\subsubsection{Ecological criteria}

Approximately 9 acres (ac) (4 hectares [ha]) of the contaminated portion of Johnson Wash are wetlands while there are 22 ac (9 ha) of wetlands in the contaminated portion of Lay Creek (Opdycke, 1986). Wetland and riparian habitat provides the most diverse wildlife habitat in the arid west, yet represents only a very small portion of the available wildlife habitat. For example, within the U.S. Bureau of Land Management's Little Snake River Resource Area, in which the Maybell site is located, riparian plant communities comprise only 0.2 percent of the vegetative cover (BLM, 1986).

\subsubsection{Radiological criteria}

The level of radiological contamination along Johnson Wash and Lay Creek was assessed to determine if leaving the contamination in place along the major portion of these two streams would be protective of human health and the environment. An assessment was performed because the DOE is committed to not impacting floodplains and wetlands if possible, and because wetlands occur along Johnson Wash and Lay Creek.

An analysis of archived sediment and test pit samples was used to determine the level of radionuclide contamination along Johnson Wash and Lay Creek. The major contaminants of concern are radium-226 (Ra-226) and thorium-230 (Th-230). Potential radiological risks from leaving contamination in place include livestock ingestion of contaminated vegetation and water, and radon emanation from contamination left in the soil.

The concentrations of Ra-226 and Th-230 in sediments in Johnson Wash and Lay Creek were compared to background levels. Radiological data are presented in Section 3.5. "Radiation," of the environmental assessment (EA). Background data are presented in Table 3.4 of the EA and Ra-226 and Th-230 data for Johnson Wash and Lay Creek are presented in Tables 3.5 and 3.6 of the EA, respectively. Following cleanup of the two areas along Johnson Wash and at the confluence of Johnson Wash and Lay Creek, the estimated average remaining Ra-226 and Th-230 contamination levels would be below the U.S. Environmental Protection Agency (EPA) cleanup standard of 5.0 picocuries per gram (pCi/g) (185 millibecquerels per gram [mBq/g]) above background (40 CFR 192).

Livestock currently graze in Johnson Wash and, therefore, there is a potential for radionuclide uptake from cattle eating contaminated plants and subsequent human consumption of contaminated animal tissues. Consumption of such 
tissues has been shown to be of concern in uranium mining and milling districts in New Mexico (Lapham et al., 1986). Average radionuclide concentrations in the 0 to 6 -inch (in) (O to 15.2 centimeters [cm]) sediment layer from Johnson Wash were used to predict concentrations in vegetation and muscle tissue for cattle grazing in Johnson Wash. The average Ra-226 and Th-230 concentrations in 0- to 6 -in $(0-$ to $15.2-\mathrm{cm})$ surface sediment layers for all locations sampled in Johnson Wash were 5.7 and $28 \mathrm{pCi} / \mathrm{g}(210.9$ and 1036 $\mathrm{mBq} / \mathrm{g}$ ), respectively (DOE, 1990). The total effective 50-year dose commitment to an individual consuming muscle tissue from cattle which feed in Johnson Wash is calculated to be 6.0 millirem (mrem) $(0.06$ millisieverts [mSv]) per year of ingestion. This dose would correspond to an annual risk of $2.4 \mathrm{x}$ $10^{-6}$, or one chance in 420,000 of contracting a fatal cancer. This risk is less than the acceptable annual limit of one excess death per 100,000 individuals established by the International Commission on Radiological Protection (ICRP, 1981).

Since standing water does occur in localized areas along Johnson Wash, cattle may consume contaminated surface water. Laboratory analysis of surface water from Johnson Wash indicates an average unfiltered uranium concentration of 80 picocuries per liter $\left(2.96 \times 10^{6}\right.$ millibecquerels per cubic meter). The estimated effective 50-year dose commitment to an individual consuming muscle tissue of cattle drinking such surface water was below $1 \mathrm{mrem}$ $(0.01 \mathrm{mSv})$ per year and would represent an insignificant risk.

Estimates of the radon flux were obtained by using existing concentrations of Ra-226 in sediments. Following remediation of the two areas, the estimated radon flux in Johnson Wash and Lay Creek would be 10 picocuries per square meter per second ( $\mathrm{pCi} / \mathrm{m}^{2} \mathrm{sec}$ ) ( 370 millibecquerels per square meter per second $\left.\left[\mathrm{mBq} / \mathrm{m}^{2} \mathrm{sec}\right]\right)$ and $8.6 \mathrm{pCi} / \mathrm{m}^{2} \mathrm{sec}\left(320 \mathrm{mBq} / \mathrm{m}^{2} \mathrm{sec}\right)$, respectively. Therefore, both Johnson Wash and Lay Creek would have radon fluxes less than the EPA standard of $20 \mathrm{pCi} / \mathrm{m}^{2} \mathrm{sec}\left(740 \mathrm{mBq} / \mathrm{m}^{2} \mathrm{sec}\right)(40 \mathrm{CFR} 192.02(2)(\mathrm{i}))$ with the majority of the existing Ra-226 contamination left in place.

Based on the above analysis, the radiological risks from leaving the majority of contaminated material in Johnson Wash and Lay Creek are insignificant and pose no threat to public health or the environment.

\subsubsection{Geomorphological criteria}

If supplemental surface cleanup standards were not used and all the contaminated areas in Johnson Wash were cleaned up, the excavation of contaminated soil and sediments and the elimination of vegetation would likely have a detrimental effect on the geomorphic stability of the wash. Flow of water from basal gravel deposits has been observed in the wash. If these flows are permanently interrupted by remedial action activities in the wash, runoff may reduce the vegetative cover, resulting in an increase of erosion in the area. The application of supplemental surface cleanup standards as part of the proposed action would prevent the increase in geomorphic instability, 
particularly along the southern part of Johnson Wash where the narrow stream channel is flanked by steep-sided slopes.

Flows in Lay Creek also may be disrupted by remedial action activities. Flow disruption could lead to a reduction in the vegetative cover, resulting in stream bed and bank instability and an increase of erosion in the area.

\subsubsection{Socioeconomic criteria}

Johnson Wash and the contaminated section of Lay Creek are in a remote area; the nearest residence is $3 \mathrm{mi}(4.8 \mathrm{~km})$ southwest of the area. Maybell (unincorporated) is the closest town and is $6 \mathrm{mi}(9.6 \mathrm{~km}$ ) west-southwest of Johnson Wash and Lay Creek. The population of Maybell, which includes area ranches, is currently estimated to be approximately 100 (Johnson, 1986; Moch, 1992). The probability of human exposure to contaminated areas not cleaned up as part of the proposed remedial action is low. This probability is based on the absence of nearby inhabited dwellings and the low population density of the Maybell area.

\subsubsection{Engineering criteria}

Cleanup of the entire areas of contamination along Johnson Wash and Lay Creek would require additional engineering considerations. A haul road would need to be constructed along each drainage. Additional borrow materials would be required to replace excavated materials. Erosion control measures would be required to protect the drainages. The most difficult engineering aspect would be the temporary diversion of Lay Creek during cleanup.

The engineering considerations necessary to clean up all of the contamination along Johnson Wash and Lay Creek are achievable. However, the result would be the destruction of wetlands throughout the affected areas. Application of supplemental surface cleanup standards to the majority of these two drainages would be protective of wetland habitat. 


\subsection{FLOODPLAIN EFFECTS}

\section{$3.1 \quad$ AFFECTED ENVIRONMENTS}

Johnson Wash, an ephemeral stream, is a large gully that extends from just south of the disposal site to the main channel of Lay Creek. Basins contributing flow to Johnson Wash are shown in Figure 3.1. The northern $2500 \mathrm{ft}(760 \mathrm{~m})$ downstream from the tailings pile are shallow with moderately steep side slopes. The southern 5000 to $6000 \mathrm{ft}(1500$ to $1800 \mathrm{~m})$ of Johnson Wash become deep with steep slopes. The entire length of Johnson Wash, including the main channel and steep side slopes, has a dense to moderately dense covering of big sagebrush (Artemisia tridentata) and grasses. There are some junipers (Juniperus monosperma) (one-seed juniper) growing on the flatter side slopes of the wash.

Lay Creek is a meandering, perennial stream with a wide, flat main channel. Basins contributing flow to Lay Creek in the immediate vicinity of the site are shown in Figure 3.2. These basins are east of the site and do not include Johnson Wash. The floodplain of Lay Creek is flat and broad. The dominant plant species along the channel is baltic rush (Juncus balticus). Black greasewood (Sarcobatus vermiculatus) and big sagebrush are common in the upper floodplain area.

\section{$3.2 \quad$ FLOOD CONDITIONS}

Maximum floodflows from small basins are generally caused by intense storms, often short in duration, over a small area. Streamflow data for Lay Creek (perennial stream) near Maybell, Colorado, were limited and no data were available for Johnson Wash, an ephemeral stream. Determination of a frequency-based flood event (100-year and 500-year) is not possible. Therefore, the regional maximum flood (RMF), as defined by the U.S. Geological Survey (USGS) (Crippen and Bue, 1977), was selected as the basis for evaluating flood conditions. The RMF is based upon USGS peak discharges known to have occurred at locations throughout the conterminous United States. The peak discharge data allow for determining reasonable estimates of the maximum floodplains in various geographical regions. Although the RMF is not a frequency-based event, the peak flows of the RMF often approach flows determined for a probable maximum flood. Thus, water surface elevations during the RMF will be much higher than those occurring during the 100-year flood.

The HEC-1 (COE, 1981) computer model was used to simulate the RMF (Crippen and Bue, 1977) of Johnson Wash and Lay Creek and the water surface elevations (flood stages) of representative reaches of the two streams. The water surface elevations of Johnson Wash and Lay Creek during half of an RMF were also generated using the HEC-1 (COE, 1981) model. 


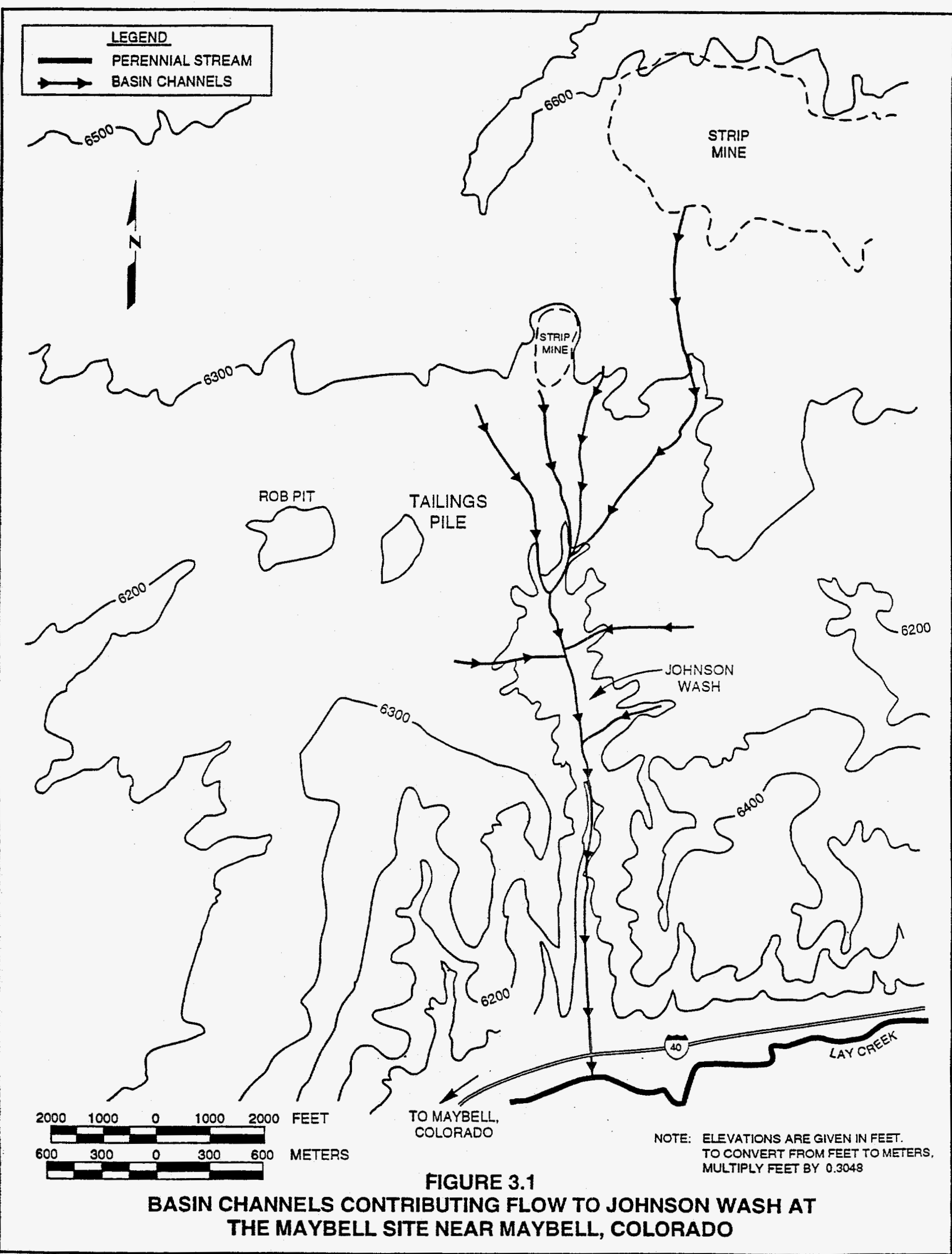




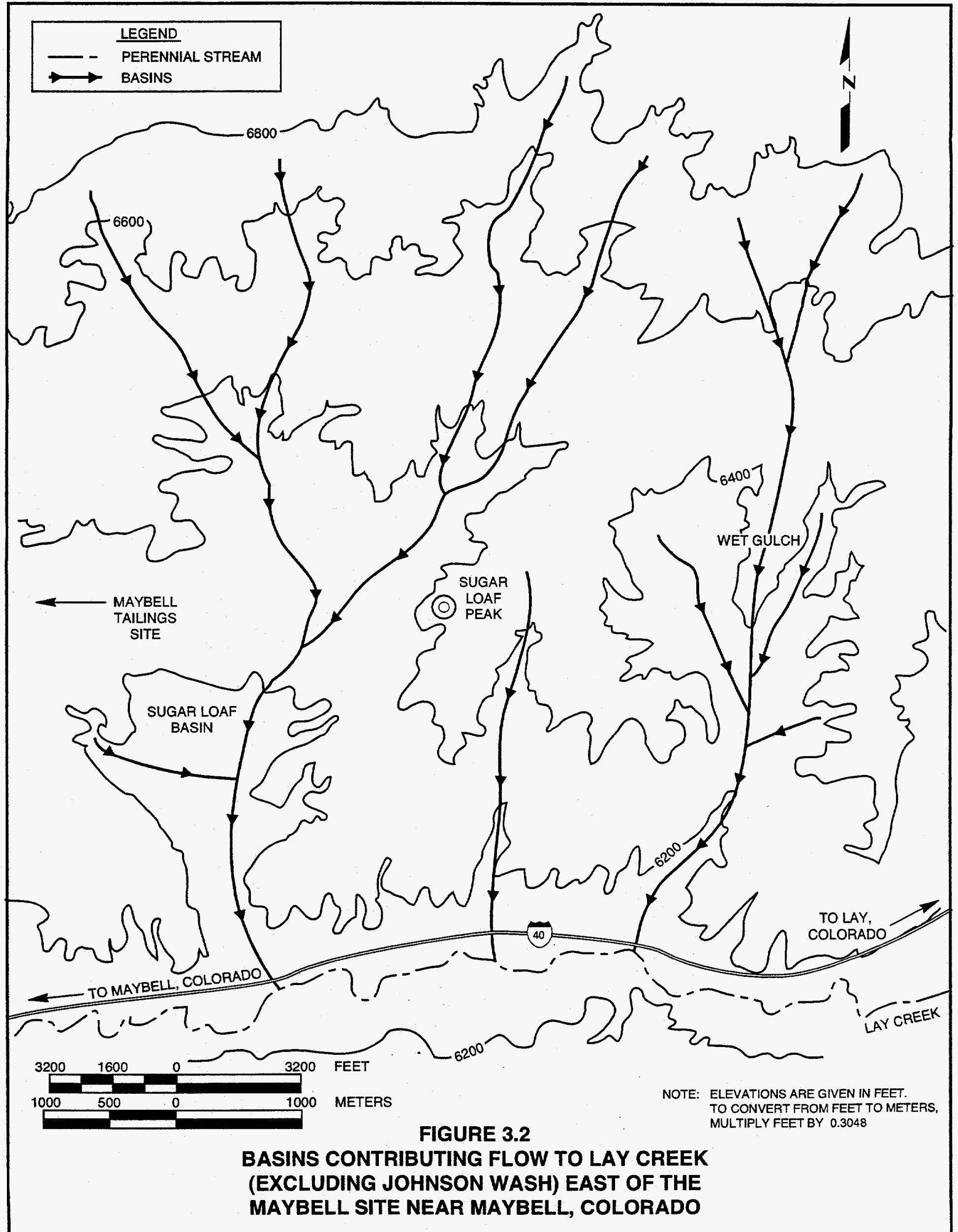


The RMF of Johnson Wash is 13,500 cubic feet per second $\left(\mathrm{ft}^{3} / \mathrm{sec}\right)(382,000$ liters per second [L/sec]) while the RMF of Lay Creek, including runoff from the large basins east of the disposal site to the town of Lay Colorado, would be $61,000\left(\mathrm{ft}^{3} / \mathrm{sec}\right)(1,700,000 \mathrm{~L} / \mathrm{sec})$. The average and peak flood stages (water surface elevation) for Johnson Wash and a reach of Lay Creek south of the disposal site for both the RMF and half of an RMF are presented on Table 3.1. For this analysis, the representative elevation above mean sea level (MSL) for the southern reach of Johnson Wash was $6040 \mathrm{ft}(1841 \mathrm{~m})$ and for Lay Creek near its confluence with Johnson Wash was $6030 \mathrm{ft}(1838 \mathrm{~m})$.

Runoff from a major flood would be confined within the main channel in the southern reach of Johnson Wash. In the northern reach of the wash, the flood boundaries of the RMF may extend up to $200 \mathrm{ft}(60 \mathrm{~m})$ on either side of the wash.

Table 3.1 Average and peak flood stages for Johnson Wash and Lay Creek

\begin{tabular}{ccccc}
\hline & \multicolumn{4}{c}{$\begin{array}{c}\text { Stage, feet above MSL } \\
\text { (meter) }\end{array}$} \\
\cline { 2 - 5 } & \multicolumn{2}{c}{ Johnson Wash ${ }^{\mathbf{a}}$} & \multicolumn{2}{c}{ Lay Creek } \\
\cline { 2 - 5 } Flood Event & Average & Peak & Average & Peak \\
\hline RMF & 6046 & 6060 & 6053 & 6073 \\
& $(1843)$ & $(1847)$ & $(1845)$ & $(1851)$ \\
$1 / 2$ RMF & 6045 & 6055 & 6047 & 6061 \\
& $(1843)$ & $(1846)$ & $(1843)$ & $(1847)$ \\
\hline
\end{tabular}

asouthern reach.

The boundary of the RMF extends as much as 500 to $700 \mathrm{ft}(150$ to $200 \mathrm{~m})$ north of the main channel of Lay Creek and 800 to $1000 \mathrm{ft}(240$ to $300 \mathrm{~m})$ south of the main channel of the stream. The floodplain boundaries for both Lay Creek and Johnson Wash during the RMF are presented on Figure 3.3.

\section{$3.3 \quad$ IMPACTS}

Based on the proposed remedial action plan, no sections of the main channels, or floodplains of either Johnson Wash or Lay Creek, would be significantly disturbed during the remedial action at the Maybell disposal site. Remediation of the two small areas along Johnson Wash and Lay Creek, comprising a total of approximately 10.2 ac $(4.1 \mathrm{ha})$, would involve construction activities consisting of excavation, backfilling with clean soil, grading to original contours, and revegation of disturbed plant communities. Remediation of the two small 


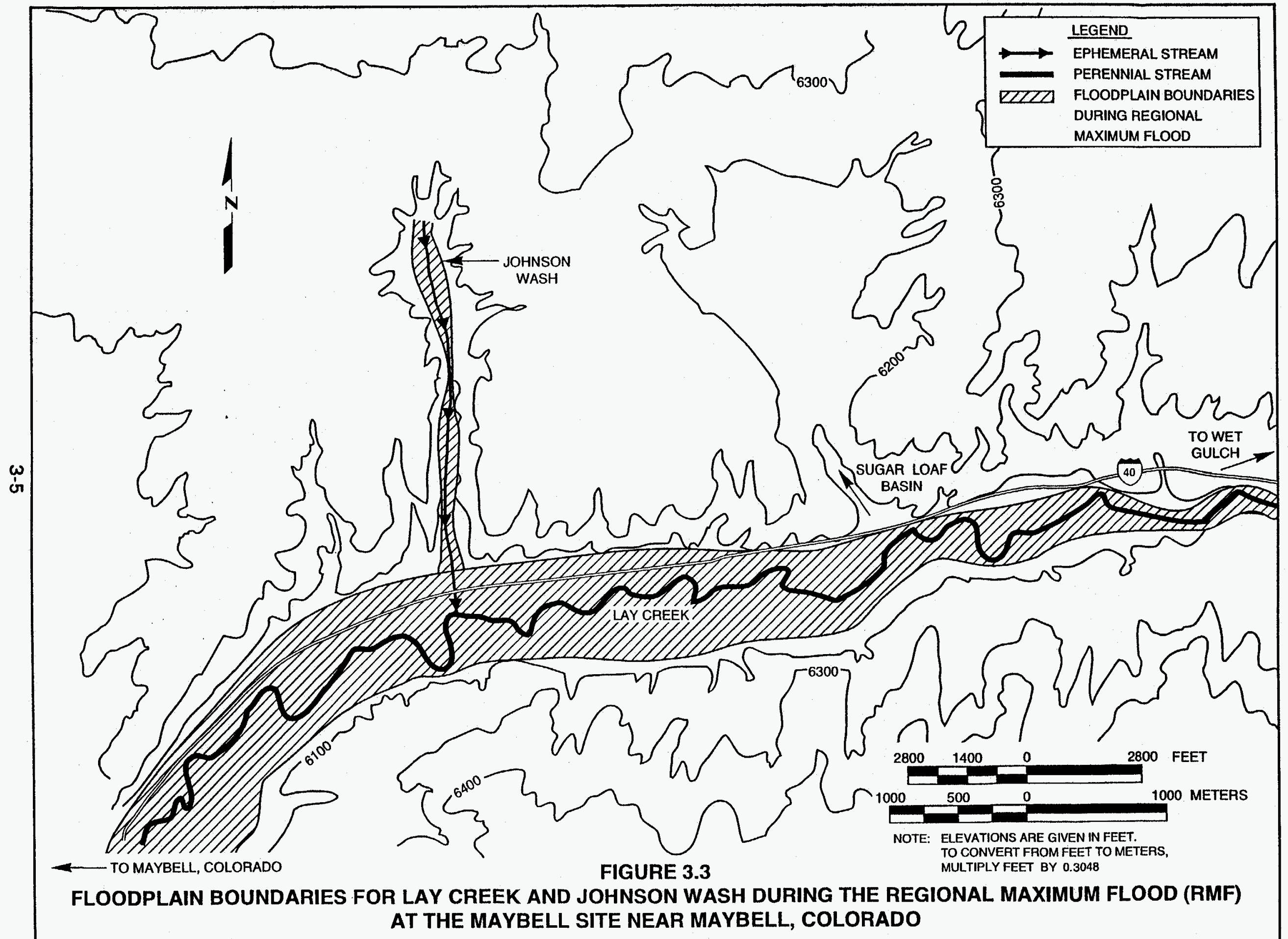


areas in comparison to the size of the two drainages would result in minimal impacts to the floodplains of Johnson Wash or Lay Creek. 


\subsection{WETLAND EFFECTS}

\subsection{AFFECTED ENVIRONMENT}

The wetland plant communities in the contaminated portions of Johnson Wash and Lay Creek occur in three distinct types. The first type occurs along Johnson Wash where the channel widens, approximately $3000 \mathrm{ft}(900 \mathrm{~m})$ downstream of the tailings pile. Species typical of disturbed conditions are common in this area and include yellow sweet clover (Meliotus officinalis), tumble mustard (Sisymbrium altissimum), Rocky Mountain bee plant (Cleome serrulata), mustard (Brassica sp.), yarrow (Achillea millefolium), Canada thistle (Cirsium arvense), bull thistle (Cirsium vulgare), and yellow salsify (Tragopogon dubius). In addition, such species as baltic rush and sedge (Carex sp.) also occur. Grass species, particularly foxtail barley (Hordeum jubatum), are also common. Observations during the summer and spring (July 1986 and May 1989) indicated that the ground was moist within some of the area (TAC, 1986; 1989) while in the fall (September 1992), the area was dry (TAC, 1992).

The second wetland type starts in Johnson Wash about $3500 \mathrm{ft}(1100 \mathrm{~m})$ downstream from the tailings pile and continues almost to its confluence with Lay Creek. In this area, there is increased soil moisture and the growth of early successional plants gives way to a dominance of more wetland species such as baltic rush and sedge (Carex sp.). Foxtail barley is still common and white clover (Trifolium repens) forms dense patches in some areas. Two springs form surface flows in this plant community.

Both wetland types in Johnson Wash have been heavily impacted by grazing cattle and have had very heavy grazing use according to the livestock grazing patterns developed by Platts and Nelson (1985). Heavily used cattle trails run the length of this wash and many plant species are grazed to ground level. The dominance of foxtail barley in many areas can be attributed to cattle selectively avoiding grazing on this species. Many of the wetland species such as baltic rush and Carex have been heavily grazed and the almost complete absence of woody species such as willow (Salix sp.) is the result of grazing pressure. Observations in 1986 and 1989 indicated that wetland vegetation was growing in and along the flowing water in the springs (TAC, 1986; 1989). In 1992, the vegetation in and along the springs had been totally eliminated by a combination of cattle grazing and trampling (TAC, 1992):

The third riparian type occurs along Lay Creek. This creek is spring fed and holds water all year. It is typically 4 to $12 \mathrm{ft}(1.2$ to $3.7 \mathrm{~m})$ wide, 6 to 12 in $(15$ to $30 \mathrm{~cm})$ deep, and is bordered by a dense stand of baltic rush which is 2 to $4 \mathrm{ft}(0.6$ to $1.2 \mathrm{~m})$ high. Other common wetland plant species observed include softstem bulrush (Scirpus sp.), rabbitfoot grass (Po/ypogon monspeliensis), cattail (Typha sp.), arrowhead (Sagittaria sp.), and inland saltgrass (Distichlis stricta). During periods when the only water source is from springs, there are relatively long stretches of standing water interspersed with 
stretches of dry creek bed (TAC, 1986; 1992). Areas of standing water typically have a growth of algae.

The wetland plant community along Lay Creek is less intensively grazed than Johnson Wash. There is a lack of well used livestock trails and the plant species have been relatively lightly grazed. Horses, rather than cattle, were the principal livestock grazing this area.

Wetlands in the contaminated sections of Johnson Wash and Lay Creek were mapped by the U.S. Fish and Wildife Service (FWS) (Figure 4.1)

(Opdycke, 1986). Using the Cowardin et al. (1979) wetland classification system, the FWS determined that there were 9.0 ac (4 ha) of wetlands along Johnson Wash comprised of 7 ac ( $3 \mathrm{ha}$ ) of palustrine emergent/temporarily flooded wetland, 2 ac (1 ha) of riverine intermittent streambed/temporarily flooded wetland, and $0.2 \mathrm{ac}(0.08 \mathrm{ha})$ of palustrine unconsolidated bottom/semipermanently flooded wetland. A total of 22 ac (9 ha) of wetlands were mapped along Lay Creek; 14 ac (6 ha) were the riverine intermittent streambed/temporarily flooded type and 8 ac ( $3 \mathrm{ha}$ ) were the palustrine emergent/temporarily flooded type. Field surveys by the U.S. Army Corps of Engineers (COE) in 1989 and 1992 determined that the wetlands mapped by the FWS are also COE-regulated wetlands (Davis, 1989; Mezei, 1992).

Under the proposed action, the upper part of Johnson Wash within the windblown-contaminated area would be remediated, as would two "hot spots" that are contaminated as a result of waterborne contaminant transport. One hot spot is located approximately $3000 \mathrm{ft}(900 \mathrm{~m})$ east of the tailings pile in Johnson Wash as it crosses under a county road. The second hot spot is also in Johnson Wash and is located south of the tailings pile near the confluence of Johnson Wash and Lay Creek. These areas are within the upland plant communities and contain no wetlands. Supplemental surface cleanup standards are proposed for the remainder of the contaminated areas of Johnson Wash and Lay Creek. Therefore, none of the wetlands along these two drainages would be affected by the proposed action. 


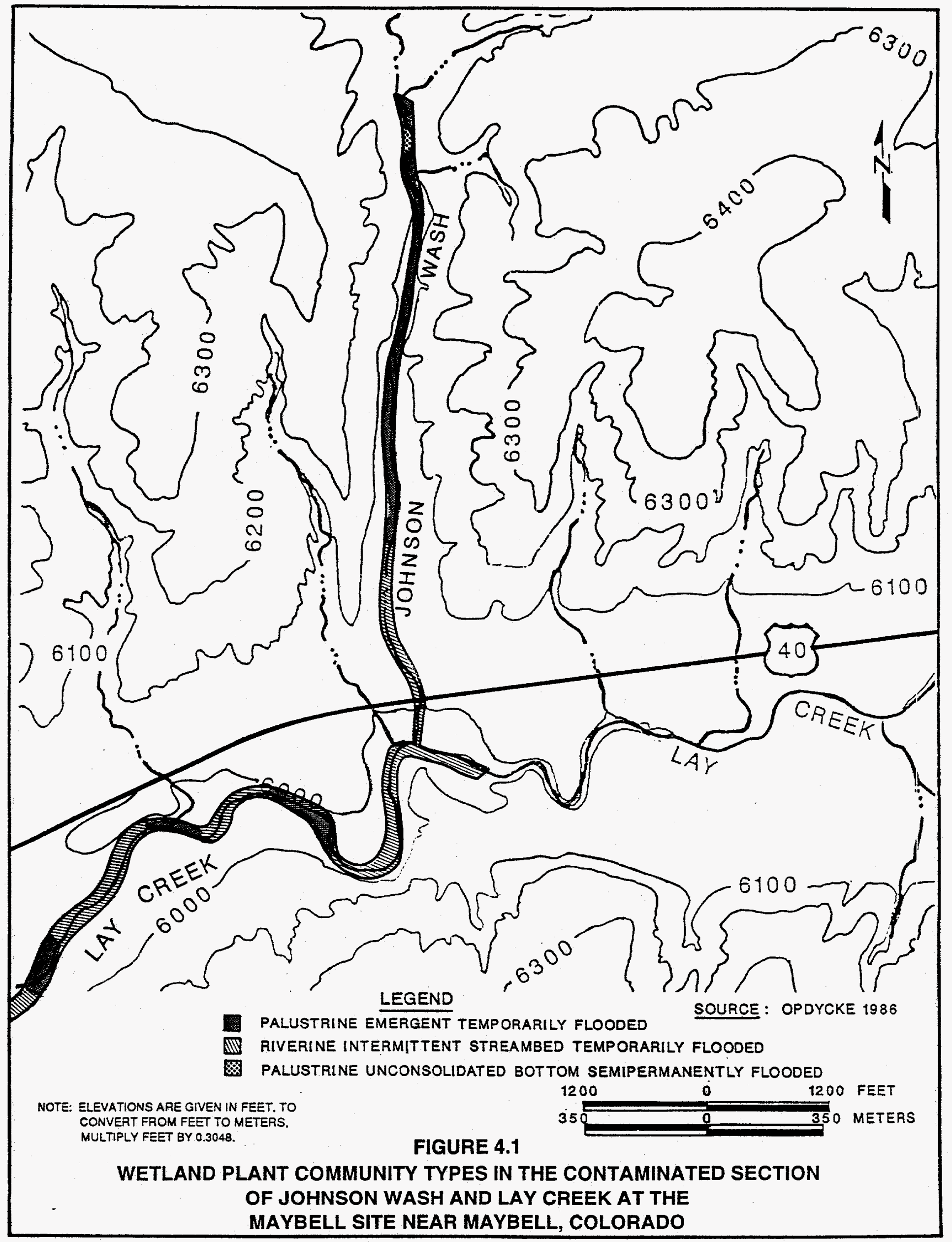




\subsection{ALTERNATIVES}

The DOE Compliance with Floodplain/Wetlands Environmental Review Requirements requires that alternatives to the proposed action be considered which may avoid adverse impacts to floodplains or wetlands (10 CFR 1022.12(a)(3)). Since the proposed action will not impact floodplains or wetlands, the consideration of an alternative to lessen or eliminate the impacts is not required. However, there is a chance that the application for supplemental surface cleanup standards may not be approved by the Nuclear Regulatory Commission and/or the Colorado Department of Health, and the contamination in Johnson Wash and Lay Creek would need to be cleaned up. The types of impacts that would be expected, if it were determined that these areas should be cleaned up are:

- Destruction of 31 ac (13 ha) of wetlands.

- Construction of a haul road along the steep-sided slopes in lower Johnson Wash and along Lay Creek.

- Removal of contaminated sediments which are up to $4 \mathrm{ft}(1.2 \mathrm{~m})$ deep in the upper reach of Johnson Wash nearest the existing tailings pile.

- Potential loss of geomorphic stability in stream beds, stream banks, and floodplains.

- Construction of erosion protection measures, such as check dams.

- Removal of soil from a borrow site to replace the sediments extracted out of Johnson Wash and Lay Creek.

- Diversion of Lay Creek while the contamination in the creek bed is being excavated.

- Dewatering of the extracted sediments.

If it is determined that supplemental surface cleanup standards are not appropriate and that the cleanup of all contaminated material along Johnson Wash and Lay Creek is required, this floodplain/wetlands assessment will be revised to address the impacts of this action. 


\subsection{REFERENCES}

BLM (Bureau of Land Management), 1986. "Little Snake Resource Management Plan and Environmental Impact Statement," BLM, Craig, Colorado.

COE (U.S. Army Corps of Engineers), 1981. HEC-1 Flood Hydrograph Package, User's Manual, Computer Program 723-X6-L2010, Water Resources Support Center, The Hydrologic Engineering Center, Davis, California.

Cowardin et al. (L. M. Cowardin, V. Carter, F. C. Golet, and E. T. LaRoe), 1979. "Classification of Wetlands and Deepwater Habitats of the United States," FWS/OBS-79/31, Office of Biological Services, U.S. Fish and Wildlife Service, Washington D.C.

Crippen, J. R., and C. D. Bue, 1977. Maximum Floodflows in the Conterminous United States, U.S. Geological Survey, Water Supply Paper 1887, U.S. Government Printing Office, Washington, D.C.

DOE (U.S. Department of Energy), 1990. Environmental Analysis and Data Report for the Maybell, Colorado, UMTRA Project Site, September 1990, U.S. Department of Energy, Uranium Mill Tailings Remedial Action Project, Albuquerque, New Mexico.

Davis, G., 1989. U.S. Army Corps of Engineers, Grand Junction, Colorado, personal communication with Charles J. Burt, Environmental Services Department, Jacobs Engineering Group Inc., Albuquerque, New Mexico, May 5, 1989.

ICRP (International Commission on Radiological Protection), 1981. Limits for Intakes of Radionuclides by Workers, ICRP Publication 30, Pergamon Press, Elmsford, New York.

Johnson, B., 1986. Resident deputy, Moffat County Sheriff's Department, Maybell, Colorado, personal communication to Sandra Beranich, Environmental Services Department, Jacobs Engineering Group Inc., Albuquerque, New Mexico, September 25, 1986.

Lapham et al. (S. C. Lapham, J. B. Millard, and J. M. Samet), 1986. "Health Implications of Radionuclide Levels in Cattle Raised Near Uranium Mining and Milling Facilities in Ambrosia Lake, New Mexico," in Health Physics, Vol. 56, No. 3, pp. 327-340.

Mezei, N., 1992. U.S. Army Corps of Engineers, Grand Junction, Colorado, personal communication with Charles'J. Burt, Environmental Services Department, Jacobs Engineering Group, Inc., Albuquerque, New Mexico, September 17. 1992. 
Moch, J., 1992. Community Development Secretary, City Hall, Craig, Colorado, personal communication to Sandra Beranich, Environmental Services Department, Jacobs Engineering Group Inc., Albuquerque, New Mexico, September 21, 1992.

Opdycke, J., 1986. "Wetland and Raptor Inventory of the Maybell Site," prepared by the U.S. Fish and Wildlife Service, Grand Junction, Colorado, for the U.S. Department of Energy, UMTRA Project Office, Albuquerque, New Mexico.

Platts, W. S., and R. L. Nelson, 1985. "Stream Habitat and Fisheries Response to Livestock Grazing and Instream Improvement Structures, Big Creek, Utah," Journal of Soil and Water Conservation, July and August, 1985, pp. 374-379.

TAC (Technical Assistance Contractor), 1992. "Unpublished Field Notes, Maybell, Colorado, Uranium Mill Tailings Site," unpublished report prepared by the Technical Assistance Contractor (Jacobs-Weston Team), Albuquerque, New Mexico, for the U.S. Department of Energy, UMTRA Project Office, Albuquerque Operations Office, Albuquerque, New Mexico.

TAC (Technical Assistance Contractor), 1989. "Unpublished Field Notes, Maybell, Colorado, Uranium Mill Tailings Site," unpublished report prepared by the Technical Assistance Contractor (Jacobs-Weston Team), Albuquerque, New Mexico, for the U.S. Department of Energy, UMTRA Project Office, Albuquerque Operations Office, Albuquerque, New Mexico.

TAC (Technical Assistance Contractor), 1986. "Unpublished Field Notes, Maybell, Colorado, Uranium Mill Tailings Site," unpublished report prepared by the Technical Assistance Contractor (Jacobs-Weston Team), Albuquerque, New Mexico, for the U.S. Department of Energy, UMTRA Project Office, Albuquerque Operations Office, Albuquerque, New Mexico.

\section{CODE OF FEDERAL REGULATIONS}

40 CFR 192, "Health and Environmental Protection Standards for Uranium and Thorium Mill Tailings," Code of Federal Regulations, Vol. 40, Part 192, U.S.

Environmental Protection Agency, Office of the Federal Register, National Archives and Records Administration, Washington, D.C.

10 CFR 1022, "Compliance With Floodplain/Wetlands Environmental Review Requirements," Code of Federal Regulations, Vol. 10, Part 1022, U.S.

Department of Energy, Office of the Federal Register, National Archives and Records Administration, Washington, D.C.

\section{EXECUTIVE ORDERS}

Order 11988, Floodplain Management, May 24, 1977, Washington, D.C.

Order 11990, Protection of Wetlands, May 24, 1977, Washington, D.C. 